\title{
Regulação do Setor de Telecomunicações em 2018
}

\section{Statutes and Regulations of the Telecommunication Sector}

\author{
Márcio lorio Aranha \\ João Alberto de Oliveira Lima \\ Renata Tonicelli de Mello Quelho
}


ARANHA, M.; LIMA, J.; QUELHO, R. Regulação do Setor de Telecomunicações em 2018. Revista de Direito, Estado e Telecomunicações, v. 11, n. 2, p. 177-230, outubro 2019.

DOI: https://doi.org/10.26512/lstr.v11i2.27083 


\section{Sumário}

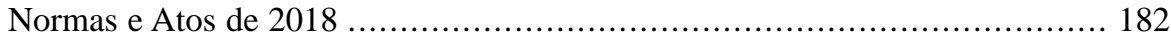

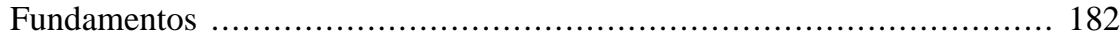

Conceitos Fundamentais ................................................. 182

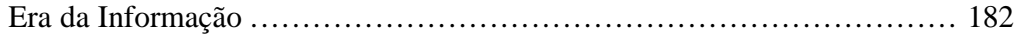

Direito à Privacidade ….................................................. 182

Infraestrutura e Recursos do Setor de Telecomunicações ...................... 182

Infraestrutura de Telecomunicações ............................................. 182

Compartilhamento de Infraestrutura ................................... 182

Redes de Telecomunicações ................................................... 183

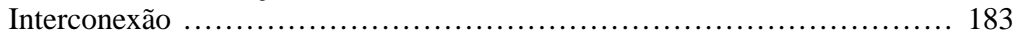

Equipamentos de Telecomunicações ........................................... 183

Espectro de Radiofrequência .............................................. 183

Atribuição, Destinação e Distribuição de Radiofrequência .................... 183

Condições de Uso de Radiofrequência e Canalização (Distribuição de

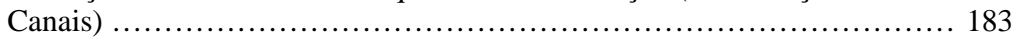

Direito de Uso de Radiofrequência .................................... 183

Administração do Setor de Telecomunicações ................................... 184

Fiscalização das Telecomunicações ................................................ 184

Tributação no Setor de Telecomunicações ........................................ 184

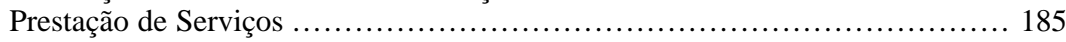

Espécies de Outorga ….............................................. 185

Concessão (regras aplicáveis) …......................................... 185

Permissão (regras aplicáveis) ................................................ 185

Autorização (regras aplicáveis) …........................................ 185

Preço Público e Preço Privado ................................................. 186

Políticas de Telecomunicações ..................................................... 186

Concorrência no Setor de Telecomunicações ...................................... 186

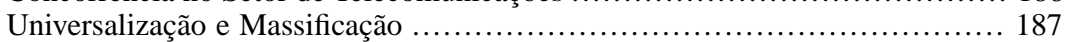

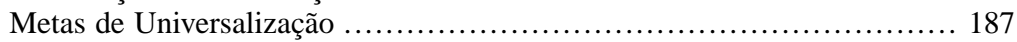

Fundos Setoriais de Telecomunicações ........................................... 187

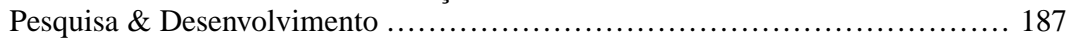

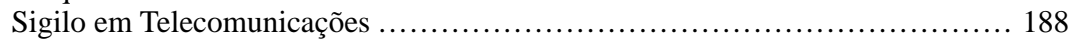

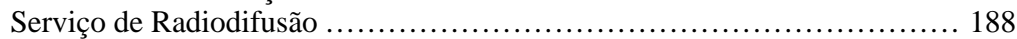

Serviços no Setor de Telecomunicações ......................................... 188

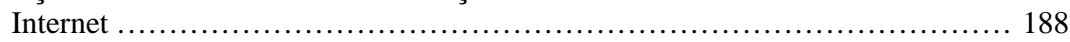

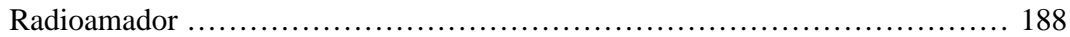

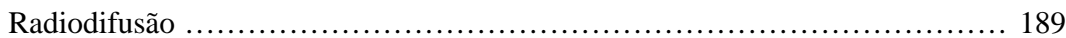

Serviço de Retransmissão de Rádio (RTR) ................................... 190

Serviço de Retransmissão de Televisão (RTV) ….......................... 190

Serviço de Repetição de Televisão (RpTV) ................................... 191

Serviço de Acesso Condicionado (SeAC) …................................... 191

Serviço de Comunicação Multimída (SCM) ..................................... 191

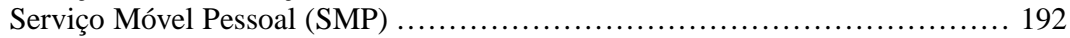

Serviço Telefônico Fixo Comutado (STFC) …................................. 193

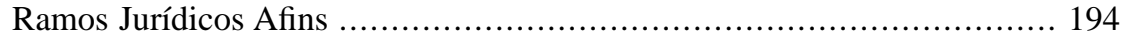

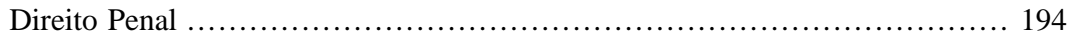

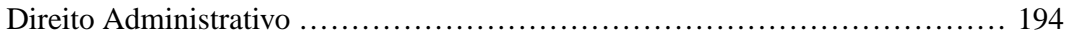

Aplicações de Telecomunicações .................................................... 194

ARANHA, M.; LIMA, J.; QUELHO, R. Regulação do Setor de Telecomunicações em 2018. Revista de Direito, Estado e Telecomunicações, v. 11, n. 2, p. 177-230, outubro 2019.

DOI: https://doi.org/10.26512/lstr.v11i2.27083 
Aplicações Educacionais ...................................................... 194

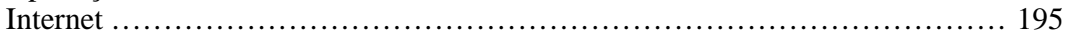

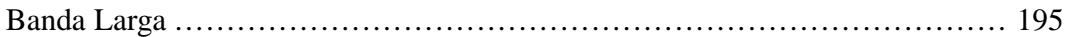

Governança Digital .................................................... 196

Atores no Setor de Telecomunicações ....................................... 196

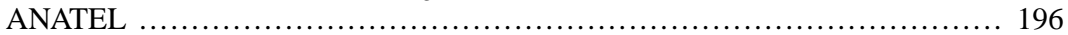

Poder Executivo ........................................................ 196

Presidência da República ............................................. 196

Ministério da Ciência, Tecnologia, Inovações e Comunicações .............. 196

Ministério do Planejamento, Orçamento e Gestão ......................... 197

Poder Judiciário ............................................................ 197

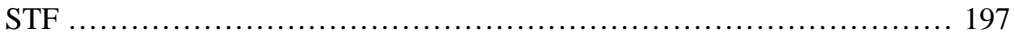

Prestadora / Operadora .................................................... 197

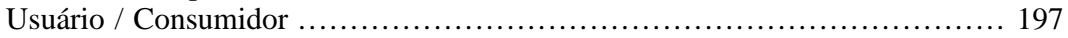

Estado-Membro ....................................................... 198

Normas Referenciadas .................................................... 198

Lei Ordinária ......................................................... 198

Lei $\mathrm{n}^{\circ} 13.608$, de 10 de janeiro de 2018 ................................ 198

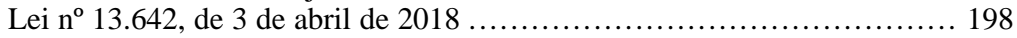

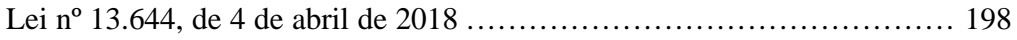

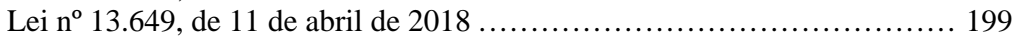

Lei $\mathrm{n}^{\circ} 13.673$, de 5 de junho de 2018 ................................... 199

Lei $\mathrm{n}^{\circ} 13.709$, de 14 de agosto de 2018 ............................... 199

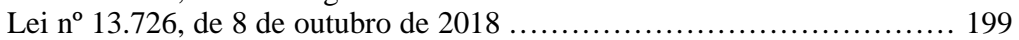

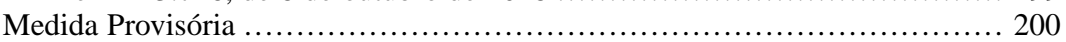

Medida Provisória no 869, de 27 de dezembro de 2018 ................... 200

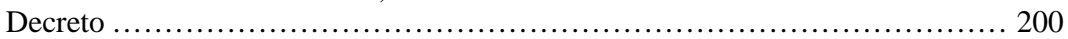

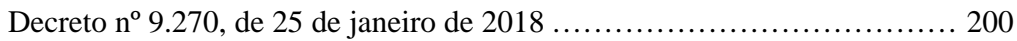

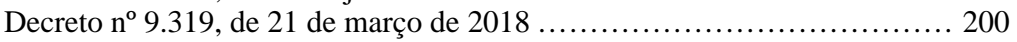

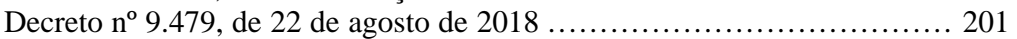

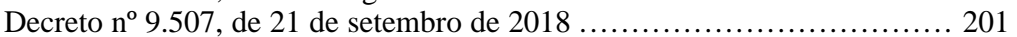

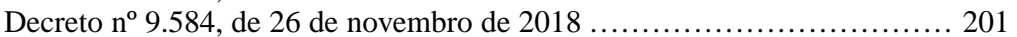

Decreto $\mathrm{n}^{\circ}$ 9.612, de 17 de dezembro de 2018 ........................... 202

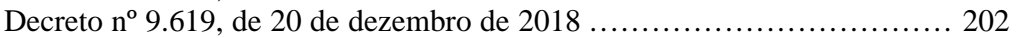

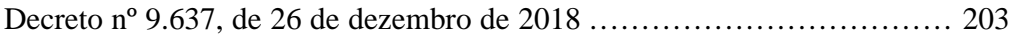

Portaria Ministerial ....................................................... 203

Portaria MCTIC no 353, de 19 de janeiro de $2018 \ldots \ldots \ldots \ldots \ldots \ldots \ldots \ldots \ldots . \ldots 203$

Portaria MCTIC n ${ }^{\circ} 699$, de 6 de fevereiro de $2018 \ldots \ldots \ldots \ldots \ldots \ldots \ldots \ldots \ldots . \ldots . \ldots . \ldots 203$

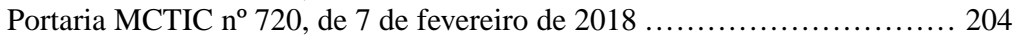

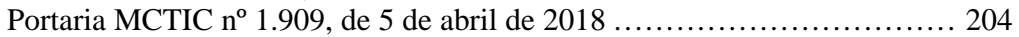

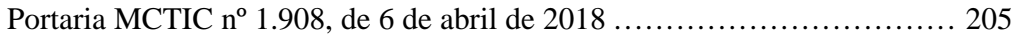

Portaria MCTIC $n^{\circ} 1.976$, de 12 de abril de $2018 \ldots \ldots \ldots \ldots \ldots \ldots \ldots \ldots . \ldots . \ldots . \ldots 205$

Portaria MCTIC no 2.105, de 16 de abril de $2018 \ldots \ldots \ldots \ldots \ldots \ldots \ldots \ldots \ldots . \ldots . \ldots . \ldots 205$

Portaria MCTIC $n^{\circ} 3.045$, de 7 de junho de $2018 \ldots \ldots \ldots \ldots \ldots \ldots \ldots \ldots \ldots \ldots . \ldots \ldots$

Portaria MCTIC $n^{\circ} 3.238$, de 20 de junho de $2018 \ldots \ldots \ldots \ldots \ldots \ldots \ldots \ldots . \ldots . \ldots . \ldots 206$

Portaria MCTIC n ${ }^{\circ}$ 6.197, de 5 de dezembro de 2018 ...................... 207

Resolução .................................................................. 207

Resolução da ANATEL n ${ }^{\circ}$ 690, de 29 de janeiro de 2018 .................. 207

Resolução da ANATEL $n^{\circ}$ 691, de 22 de fevereiro de 2018 .................... 208

Resolução da ANATEL $n^{\circ}$ 692, de 12 de abril de 2018 ..................... 209

Resolução da ANATEL $n^{\circ}$ 693, de 17 de julho de 2018 ...................... 209

Resolução da ANATEL n ${ }^{\circ}$ 694, de 17 de julho de 2018 ..................... 209

ARANHA, M.; LIMA, J.; QUELHO, R. Regulação do Setor de Telecomunicações em 2018. Revista de Direito,

Estado e Telecomunicações, v. 11, n. 2, p. 177-230, outubro 2019.

DOI: https://doi.org/10.26512/lstr.v11i2.27083 
Resolução da ANATEL n ${ }^{\circ}$ 695, de 20 de julho de 2018 ................. 210

Resolução da ANATEL n ${ }^{\circ}$ 696, de 23 de julho de 2018 .................... 211

Resolução da ANATEL n ${ }^{\circ}$ 697, de 28 de agosto de 2018 ................. 211

Resolução da ANATEL $n^{\circ}$ 698, de 27 de setembro de 2018 ................ 212

Resolução da ANATEL n ${ }^{\circ}$ 699, de 28 de setembro de 2018 ................. 212

Resolução da ANATEL n ${ }^{\circ} 700$, de 28 de setembro de 2018 ................. 212

Resolução da ANATEL n ${ }^{\circ} 701$, de 5 de outubro de 2018 ................... 213

Resolução da ANATEL $n^{\circ} 702$, de $1^{\circ}$ de novembro de 2018 ............... 213

Resolução da ANATEL $n^{\circ} 703$, de $1^{\circ}$ de novembro de $2018 \ldots \ldots \ldots \ldots \ldots . \ldots 214$

Resolução da ANATEL n ${ }^{\circ} 704$, de 6 de novembro de 2018 ................ 214

Resolução da ANATEL n ${ }^{\circ}$ 705, de 21 de dezembro de 2018 ................ 215

Julgados Referenciados ............................................. 215

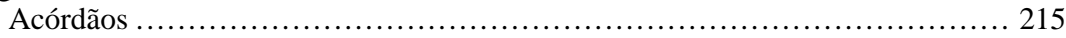

Supremo Tribunal Federal (STF) .................................. 215

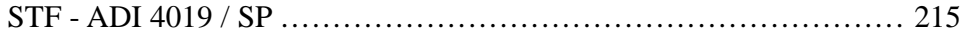

Atos Referenciados ......................................................... 215

Ato Administrativo ......................................................... 215

Decisão .......................................................... 215

Acórdão do Conselho Diretor da ANATEL, de 3 de janeiro de 2018 (Ref.

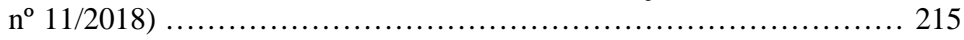

Acórdão do Conselho Diretor da ANATEL, de 20 de dezembro de 2018

(Ref. $\mathrm{n}^{\mathrm{o}}$ 726/2018) ............................................ 216

Índice Alfabético e Remissivo ............................................. 217

ARANHA, M.; LIMA, J.; QUELHO, R. Regulação do Setor de Telecomunicações em 2018. Revista de Direito, 


\section{Normas e Atos de 2018}

\section{Fundamentos}

\section{Conceitos Fundamentais}

\section{Era da Informação}

\section{Normatização}

Decreto $n^{0}$ 9.637, de 26 de dezembro de 2018 - Institui a Política Nacional de Segurança da Informação, dispõe sobre a governança da segurança da informação, e altera o Decreto ${ }^{\circ} 2.295$, de 4 de agosto de 1997, que regulamenta o disposto no art. 24, caput, inciso IX, da Lei $n^{\circ} 8.666$, de 21 de junho de 1993, e dispõe sobre a dispensa de licitação nos casos que possam comprometer a segurança nacional.

\section{Direito à Privacidade}

Tema Conexo: Políticas de Telecomunicações : Sigilo em Telecomunicações.

\section{Normatização}

Lei $\mathrm{n}^{\circ}$ 13.608, de 10 de janeiro de 2018 - Dispõe sobre o serviço telefônico de recebimento de denúncias e sobre recompensa por informações que auxiliem nas investigações policiais; e altera o art. 4o da Lei no 10.201, de 14 de fevereiro de 2001, para prover recursos do Fundo Nacional de Segurança Pública para esses fins.

$\boldsymbol{V}$ A Lei 13.608/2018 exige que a divulgação do Disque-Denúncia em veículos de concessionárias de transportes terrestres contenham expressões de garantia do anomimato.

\section{Infraestrutura e Recursos do Setor de Telecomunicações}

\section{Infraestrutura de Telecomunicações}

\section{Compartilhamento de Infraestrutura}

\section{Normatização}

Decreto $\mathbf{n}^{\circ}$ 9.612, de 17 de dezembro de 2018 - Dispõe sobre políticas públicas de telecomunicações.

$\checkmark$ O Decreto 9.612/2018, de políticas públicas de telecomunicações, determina que a implantação da infraestrutura e dos serviços baseados em TIC prioritariamente em cidades com inexistência de redes de acesso de alta capacidade, com vistas à promoção da melhoria da qualidade, à oferta de novos serviços aos cidadãos e ao aumento da eficiência dos serviços públicos, ocorrerá por meio de contrato destinados ao compartilhamento de infraestrutura, bem como elenca o compartilhamento de infraestrutura como diretriz de orientação de atuação da ANATEL.

Decreto no 9.637, de 26 de dezembro de 2018 - Institui a Política Nacional de Segurança da Informação, dispõe sobre a governança da segurança da informação, e altera o Decreto $\mathrm{n}^{\circ} 2.295$, de 4 de agosto de 1997, que regulamenta o disposto no art. 24, caput, inciso IX, da Lei ${ }^{\circ}$ 8.666, de 21 de junho de 1993, e dispõe sobre a dispensa de licitação nos casos que possam comprometer a segurança nacional. 


\section{Redes de Telecomunicações}

\section{Interconexão}

\section{Normatização}

Resolução da ANATEL no 693, de 17 de julho de 2018 - Aprova o Regulamento Geral de Interconexão - RGI e altera o Regulamento dos Serviços de Telecomunicações, o Regimento Interno da Anatel e os Regulamentos de Remuneração pelo uso de redes do Serviço Telefônico Fixo Comutado e do Serviço Móvel Pessoal.

\section{Equipamentos de Telecomunicações}

\section{Normatização}

Resolução da ANATEL no 700, de 28 de setembro de 2018 - Aprova o Regulamento sobre a Avaliação da Exposição Humana a Campos Elétricos, Magnéticos e Eletromagnéticos Associados à Operação de Estações Transmissoras de Radiocomunicação.

$\rightarrow$ Anexo - Anexo - Regulamento sobre a Avaliação da Exposição Humana a Campos Elétricos, Magnéticos e Eletromagnéticos Associados à Operação de Estações Transmissoras de Radiocomunicação

Resolução da ANATEL $\mathbf{n}^{\mathbf{0}}$ 705, de 21 de dezembro de 2018 - Altera o Regulamento sobre Equipamentos de Radiocomunicação de Radiação Restrita.

\section{Espectro de Radiofrequência}

\section{Atribuição, Destinação e Distribuição de Radiofrequência}

\section{Normatização}

Resolução da ANATEL $\mathbf{n}^{\circ}$ 697, de 28 de agosto de 2018 - Atribui e destina faixas de radiofrequência ao Serviço de Radioamador e aprova o Regulamento sobre Condições de Uso de Radiofrequências pelo Serviço de Radioamador.

- Anexo - Anexo - Regulamento sobre Condições de Uso de Radiofrequências pelo Serviço de Radioamador

\section{Condições de Uso de Radiofrequência e Canalização (Distribuição de Canais)}

\section{Normatização}

Resolução da ANATEL no 697, de 28 de agosto de 2018 - Atribui e destina faixas de radiofrequência ao Serviço de Radioamador e aprova o Regulamento sobre Condições de Uso de Radiofrequências pelo Serviço de Radioamador.

$\Rightarrow$ Anexo - Anexo - Regulamento sobre Condições de Uso de Radiofrequências pelo Serviço de Radioamador

\section{Direito de Uso de Radiofrequência}

\section{Normatização}

Resolução da ANATEL $\mathbf{n}^{\circ}$ 703, de $1^{\circ}$ de novembro de 2018 - Estabelece Limites Máximos de Quantidade de Espectro de Radiofrequências. 
$\Rightarrow$ Anexo - Anexo - Tabelas de subfaixas de radiofrequência abaixo de $1 \mathrm{GHz}$ e entre $1 \mathrm{GHz}$ e $3 \mathrm{GHz}$

Resolução da ANATEL no 705, de 21 de dezembro de 2018 - Altera o Regulamento sobre Equipamentos de Radiocomunicação de Radiação Restrita.

\section{Administração do Setor de Telecomunicações}

\section{Normatização}

Decreto $\mathbf{n}^{0}$ 9.507, de 21 de setembro de 2018 - Dispõe sobre a execução indireta, mediante contratação, de serviços da administração pública federal direta, autárquica e fundacional e das empresas públicas e das sociedades de economia mista controladas pela União.

\section{Fiscalização das Telecomunicações}

\section{Normatização}

Portaria MCTIC no 353, de 19 de janeiro de 2018 - Estabelece o valor máximo da multa por infração às disposições da Lei 4.117/62 (Código Brasileiro de Telecomunicações)

Resolução da ANATEL $\mathbf{n}^{\circ}$ 700, de 28 de setembro de 2018 - Aprova o Regulamento sobre a Avaliação da Exposição Humana a Campos Elétricos, Magnéticos e Eletromagnéticos Associados à Operação de Estações Transmissoras de Radiocomunicação.

- Anexo - Anexo - Regulamento sobre a Avaliação da Exposição Humana a Campos Elétricos, Magnéticos e Eletromagnéticos Associados à Operação de Estações Transmissoras de Radiocomunicação

\section{Atos}

Acórdão do Conselho Diretor da ANATEL, de 20 de dezembro de 2018 (Ref. $\mathbf{n}^{\circ}$ 726/2018) - Função pública de promoção da integração social por meio do acesso ao conteúdo de TV, mesmo que inscrita em lei estadual de criação de órgão da Administração Pública com dita competência, não se sobrepõe ao dever geral de obediência à prévia outorga do direito de uso de radiofrequência, de competência da União. Mora da Administração Pública federal na outorga do Serviço de Retransmissão de Televisão (RTV) e consequente uso não autorizado de radiofrequência na execução não outorgada do RTV não configuram atenuante ou excludente de ilicitude pela prática de infração de natureza grave, nos termos do art. 80 do Regulamento de Uso do Espectro de Radiofrequências (RUER/2001), aprovado pela Res. ANATEL n 259, de 19 de abril de 2001.

Acórdão do Conselho Diretor da ANATEL, de 3 de janeiro de 2018 (Ref. n $^{\circ} 11 / 2018$ ) - Não há direito à supensão de processos administrativos por descumprimento de obrigações afetas à prestadora de serviços de telecomunicações em recuperação judicial.

\section{Tributação no Setor de Telecomunicações}

\section{Normatização}

Resolução da ANATEL no 690, de 29 de janeiro de 2018 - Aprova o Regulamento de Restituição e Compensação das Receitas Administradas pela Anatel e dá outras providências.

ARANHA, M.; LIMA, J.; QUELHO, R. Regulação do Setor de Telecomunicações em 2018. Revista de Direito, Estado e Telecomunicações, v. 11, n. 2, p. 177-230, outubro 2019.

DOI: https://doi.org/10.26512/lstr.v11i2.27083 
$\Rightarrow$ Anexo - Anexo - Regulamento de Restituição e Compensação das Receitas Administradas pela Anatel

\section{Prestação de Serviços}

\section{Espécies de Outorga}

\section{Concessão (regras aplicáveis)}

\section{Normatização}

Decreto no 9.619, de 20 de dezembro de 2018 - Aprova o Plano Geral de Metas para a Universalização do Serviço Telefônico Fixo Comutado Prestado no Regime Público.

- Anexo 1 - Anexo I - Plano Geral de Metas para a Universalização do Serviço Telefônico Fixo Comutado Prestado no Regime Público

- Anexo 2 - Anexo II - Telefones de Uso Público das Concessionárias do Serviço Telefônico Fixo Comutado na Modalidade Local

$\Rightarrow$ Anexo 3 - Anexo III - Telefones de Uso Público das Concessionárias do Serviço Telefônico Fixo Comutado nas Modalidades Longa Distância Nacional e Internacional

$\Rightarrow$ Anexo 4 - Anexo IV - Localidade a serem atendidades por Sistemas de Acesso Fixo sem Fio

Resolução da ANATEL $\mathbf{n}^{\circ}$ 702, de $1^{\circ}$ de novembro de 2018 - Aprova o Regulamento de cobrança de Preço Público pelo Direito de Exploração de Satélite e estabelece o Preço Público para a autorização, a adaptação, a consolidação e a transferência de autorização, permissão e concessão de serviços de telecomunicações.

- Anexo - Anexo - Regulamento de cobrança de Preço Público pelo Direito de Exploração de Satélite

\section{Permissão (regras aplicáveis)}

\section{Normatização}

Resolução da ANATEL $n^{0}$ 702, de $1^{\circ}$ de novembro de 2018 - Aprova o Regulamento de cobrança de Preço Público pelo Direito de Exploração de Satélite e estabelece o Preço Público para a autorização, a adaptação, a consolidação e a transferência de autorização, permissão e concessão de serviços de telecomunicações.

- Anexo - Anexo - Regulamento de cobrança de Preço Público pelo Direito de Exploração de Satélite

\section{Autorização (regras aplicáveis)}

\section{Normatização}

Resolução da ANATEL $\mathbf{n}^{\circ}$ 702, de $1^{\circ}$ de novembro de 2018 - Aprova o Regulamento de cobrança de Preço Público pelo Direito de Exploração de Satélite e estabelece o Preço Público para a autorização, a adaptação, a consolidação e a transferência de autorização, permissão e concessão de serviços de telecomunicações.

- Anexo - Anexo - Regulamento de cobrança de Preço Público pelo Direito de Exploração de Satélite 


\section{Preço Público e Preço Privado}

\section{Normatização}

Resolução da ANATEL n 695, de 20 de julho de 2018 - Aprova o Regulamento de Cobrança de Preço Público pelo Direito de Uso de Radiofrequências.

$\rightarrow$ Anexo - Anexo - Regulamento de Cobrança de Preço Público pelo Direito de Uso de Radiofrequências

Resolução da ANATEL $n^{\circ}$ 702, de $1^{\circ}$ de novembro de 2018 - Aprova o Regulamento de cobrança de Preço Público pelo Direito de Exploração de Satélite e estabelece o Preço Público para a autorização, a adaptação, a consolidação e a transferência de autorização, permissão e concessão de serviços de telecomunicações.

$\rightarrow$ Anexo - Anexo - Regulamento de cobrança de Preço Público pelo Direito de Exploração de Satélite

\section{Políticas de Telecomunicações}

\section{Normatização}

Decreto $\mathbf{n}^{\mathbf{0}}$ 9.319, de 21 de março de 2018 - Institui o Sistema Nacional para a Transformação Digital e estabelece a estrutura de governança para a implantação da Estratégia Brasileira para a Transformação Digital.

$\rightarrow$ Anexo 1 - Anexo I - Eixos Temáticos da Estratégia Brasileira para a Transformação Digital - E-Digital

\section{$\Rightarrow$ Anexo 2}

Decreto $\mathrm{n}^{0}$ 9.612, de 17 de dezembro de 2018 - Dispõe sobre políticas públicas de telecomunicações.

\section{Concorrência no Setor de Telecomunicações}

\section{- Concorrência no Setor de Telecomunicações}

- O Serviço de Comunicação Multimídia apresenta-se como serviço convergente com pretensão de introduzir utilidades concorrentes às fornecidas por serviços tradicionais do setor.

\section{Normatização}

Resolução da ANATEL no 694, de 17 de julho de 2018 - Altera o Plano Geral de Metas de Competição - PGMC, aprovado pela Resolução $n^{\circ} 600$, de 8 de novembro de 2012; o Regulamento de Remuneração pelo Uso de Redes de Prestadoras do Serviço Telefônico Fixo Comutado - STFC, aprovado pela Resolução $\mathrm{n}^{\circ} 588$, de 7 de maio de 2012; o Regulamento de Remuneração pelo Uso de Redes de Prestadoras do Serviço Móvel Pessoal - SMP, aprovado pela Resolução no 438, de 10 de julho de 2006; a Resolução no 396, de 31 de março de 2005; o Regulamento de Aplicação de Sanções Administrativas, aprovado pela Resolução $\mathrm{n}^{\circ}$ 589, de 7 de maio de 2012; revoga a Resolução $n^{\circ} 437$, de 8 de junho de 2006; e dá outras providências.

- Anexo 1 - Anexo I - Diretrizes Metodológicas para Identificação de Mercado Relevante de Atacado e dos Grupos com PMS

$\rightarrow$ Anexo 2 - Anexo II - Mercados Relevantes e Medidas Regulatórias Assimétricas

$\Rightarrow$ Anexo 3 - Anexo III - Homologação de Ofertas de Referência de Produtos de Atacado 
$\Rightarrow$ Anexo 4 - Anexo IV - Categorização dos Municípios

Resolução da ANATEL no 704, de 6 de novembro de 2018 - Altera o Regulamento de Gestão da Qualidade do Serviço de Comunicação Multimídia (RGQ-SCM), aprovado pela Resolução no 574, de 28 de outubro de 2011, o Regulamento de Gestão da Qualidade da Prestação do Serviço Móvel Pessoal (RGQ-SMP), aprovado pela Resolução no ${ }^{\circ} 575$, de 28 de outubro de 2011, o Regulamento de Gestão da Qualidade da Prestação do Serviço Telefônico Fixo Comutado (RGQ-STFC), aprovado pela Resolução ${ }^{\circ} 605$, de 26 de dezembro de 2012, o Regulamento do Serviço de Comunicação Multimídia, aprovado pela Resolução ${ }^{\circ}$ 614, de 28 de maio de 2013, e o Regulamento Geral de Direitos do Consumidor de Serviços de Telecomunicações - RGC, Resolução $n^{\circ} 632$, de 7 de março de 2014.

\section{Universalização e Massificação}

\section{Metas de Universalização}

\section{Normatização}

Decreto no 9.619, de 20 de dezembro de 2018 - Aprova o Plano Geral de Metas para a Universalização do Serviço Telefônico Fixo Comutado Prestado no Regime Público.

$\Rightarrow$ Anexo 1 - Anexo I - Plano Geral de Metas para a Universalização do Serviço Telefônico Fixo Comutado Prestado no Regime Público

- Anexo 2 - Anexo II - Telefones de Uso Público das Concessionárias do Serviço Telefônico Fixo Comutado na Modalidade Local

- Anexo 3 - Anexo III - Telefones de Uso Público das Concessionárias do Serviço Telefônico Fixo Comutado nas Modalidades Longa Distância Nacional e Internacional

$\Rightarrow$ Anexo 4 - Anexo IV - Localidade a serem atendidades por Sistemas de Acesso Fixo sem Fio

\section{Atos}

Acórdão do Conselho Diretor da ANATEL, de 3 de janeiro de 2018 (Ref. $n^{\circ} 11 / 2018$ )

- Não há direito à supensão de processos administrativos por descumprimento de obrigações afetas à prestadora de serviços de telecomunicações em recuperação judicial.

\section{Fundos Setoriais de Telecomunicações}

\section{Normatização}

Resolução da ANATEL no 690, de 29 de janeiro de 2018 - Aprova o Regulamento de Restituição e Compensação das Receitas Administradas pela Anatel e dá outras providências.

$\rightarrow$ Anexo - Anexo - Regulamento de Restituição e Compensação das Receitas Administradas pela Anatel

\section{Pesquisa \& Desenvolvimento}

\section{Normatização}

Resolução da ANATEL no 691, de 22 de fevereiro de 2018 - Cria Centro de Altos Estudos em Telecomunicações - Ceatel e dá outras providências 


\section{Sigilo em Telecomunicações}

Tema Conexo: Fundamentos : Conceitos Fundamentais : Direito à Privacidade.

\section{Normatização}

Decreto $\mathbf{n}^{\mathbf{0}}$ 9.637, de 26 de dezembro de 2018 - Institui a Política Nacional de Segurança da Informação, dispõe sobre a governança da segurança da informação, e altera o Decreto $\mathrm{n}^{\circ} 2.295$, de 4 de agosto de 1997, que regulamenta o disposto no art. 24, caput, inciso IX, da Lei ${ }^{\circ}$ 8.666, de 21 de junho de 1993, e dispõe sobre a dispensa de licitação nos casos que possam comprometer a segurança nacional.

\section{Serviço de Radiodifusão}

Tema Conexo: Serviços no Setor de Telecomunicações : Radiodifusão.

\section{Serviços no Setor de Telecomunicações}

\section{Internet}

\section{Normatização}

Lei $\mathbf{n}^{\mathbf{0}}$ 13.642, de 3 de abril de 2018 - Altera a Lei ${ }^{\circ}$ 10.446, de 8 de maio de 2002, para acrescentar atribuição à Polícia Federal no que concerne à investigação de crimes praticados por meio da rede mundial de computadores que difundam conteúdo misógino, definidos como aqueles que propagam o ódio ou a aversão às mulheres.

Lei $\mathbf{n}^{0}$ 13.709, de 14 de agosto de 2018 [ (1) ] - Dispõe sobre a proteção de dados pessoais e altera a Lei $n^{\circ} 12.965$, de 23 de abril de 2014 (Marco Civil da Internet)

Medida Provisória no 869, de 27 de dezembro de 2018 - Altera a Lei $n^{\circ}$ 13.709, de 14 de agosto de 2018, para dispor sobre a proteção de dados pessoais e para criar a Autoridade Nacional de Proteção de Dados, e dá outras providências.

Decreto $\mathbf{n}^{\circ}$ 9.584, de 26 de novembro de 2018 - Altera o Decreto $\mathrm{n}^{\circ} 8.638$, de 15 de janeiro de 2016, para instituir a Rede Nacional de Governo Digital.

Decreto $\mathrm{n}^{\circ}$ 9.637, de 26 de dezembro de 2018 - Institui a Política Nacional de Segurança da Informação, dispõe sobre a governança da segurança da informação, e altera o Decreto $\mathrm{n}^{\circ} 2.295$, de 4 de agosto de 1997, que regulamenta o disposto no art. 24, caput, inciso IX, da Lei $\mathrm{n}^{\circ}$ 8.666, de 21 de junho de 1993, e dispõe sobre a dispensa de licitação nos casos que possam comprometer a segurança nacional.

\section{Radioamador}

\section{Normatização}

Resolução da ANATEL $\mathbf{n}^{\circ}$ 697, de 28 de agosto de 2018 - Atribui e destina faixas de radiofrequência ao Serviço de Radioamador e aprova o Regulamento sobre Condições de Uso de Radiofrequências pelo Serviço de Radioamador.

$\Rightarrow$ Anexo - Anexo - Regulamento sobre Condições de Uso de Radiofrequências pelo Serviço de Radioamador 


\section{Radiodifusão}

Temas Conexos: Classificações de Serviços no Setor de Telecomunicações : Quanto ao Gênero : Serviço de Radiodifusão e Atores no Setor de Telecomunicações : Poder Executivo : Ministério das Comunicações.

Competência da Presidência da República para outorgar, por meio de concessão, a exploração dos serviços de radiodifusão de sons e imagens, e do Ministério das Comunicações para outorgar, por meio de concessão, permissão ou autorização, a exploração dos serviços de radiodifusão sonora.

\section{Normatização}

Lei $\mathbf{n}^{\circ}$ 13.644, de 4 de abril de 2018 - Altera a Lei no 4.117, de 27 de agosto de 1962, para dispor sobre o horário de retransmissão obrigatória do programa oficial dos Poderes da República pelas emissoras de radiodifusão sonora.

Decreto ${ }^{0}$ 9.270, de 25 de janeiro de 2018 - Fixa prazo para manifestação de interesse na adaptação de outorga do serviço de radiodifusão sonora em onda média, de caráter local, regional e nacional, para a execução do serviço de radiodifusão em frequência modulada.

Portaria MCTIC n⿳⺈ 353, de 19 de janeiro de 2018 - Estabelece o valor máximo da multa por infração às disposições da Lei 4.117/62 (Código Brasileiro de Telecomunicações)

Portaria MCTIC no 699, de 6 de fevereiro de 2018 [ (1) ] - Disciplina e aprova as regras para utilização de canais virtuais pelas entidades executantes dos serviços de radiodifusão de sons e imagens e de retransmissão de televisão do Sistema Brasileiro de Televisão Digital Terrestre - SBTVD- T.

$\rightarrow$ Anexo - Anexo - Declaração sobre Utilização de Redes de Frequência Única (SFN - Single Frequency Networks) para Designação de Canal Virtual (RTVD)

Portaria MCTIC no 1.909, de 5 de abril de 2018 - Altera a Portaria n ${ }^{\circ}$ 4.334/2015/SEIMC, que dispõe sobre o serviço de radiodifusão comunitária.

Portaria MCTIC n $\mathbf{0} .908$, de 6 de abril de 2018 - Altera a Portaria MCTIC n ${ }^{\circ}$ 699, de 06.02.2018, que disciplina e aprova as regras para utilização de canais virtuais pelas entidades executantes dos serviços de radiodifusão de sons e imagens e de retransmissão de televisão do Sistema Brasileiro de Televisão Digital Terrestre - SBTVD- T.

Portaria MCTIC $\mathrm{n}^{\circ}$ 1.976, de 12 de abril de 2018 - Altera a Portaria $\mathrm{n}^{\circ}$ 4.334/2015/SEI-MC, que dispõe sobre o serviço de radiodifusão comunitária

Portaria MCTIC n $\mathbf{n}^{0}$ 2.105, de 16 de abril de 2018 - Estabelece a exibição de cartela informativa pelas entidades que executam o serviço de Radiodifusão de Sons e Imagens e o serviço de Retransmissão de Televisão, em tecnologia digital, que alterarem seu canal físico, orientando a população quanto aos procedimentos de sintonia do novo canal.

Portaria MCTIC no ${ }^{0}$.045, de 7 de junho de 2018 - Dispõe sobre a destinação do saldo de recursos remanescente, proveniente da licitação de que trata o Edital n $2 / 2014$ SOR/SPR/CD-ANATEL, administrados pela Associação Administradora do Processo de Redistribuição e Digitalização de Canais de TV e RTV - EAD.

Portaria MCTIC no 3.238, de 20 de junho de 2018 - Dispõe sobre permissão e concessão para execução dos serviços de radiodifusão sonora em frequência modulada e de sons e imagens, com fins exclusivamente educativos. 
$\Rightarrow$ Anexo 1 - Anexo I - Requerimento de Outorga para Pessoas Jurídicas de Direito Público

$\Rightarrow$ Anexo 10 - Anexo X - Requerimento de Transferência de Outorga para quando a Cedente for Instituição de Educação Superior de Natureza Privada e a Cessionária for Pessoa Jurídica de Direito Público ou outra Instituição de Educação Superior de Natureza Privada

$\rightarrow$ Anexo 11 - Anexo XI - Requerimento de Transferência de Outorga para quando a Cedente for Fundação de Direito Privado e a Cessionária for Pessoa Jurídica de Direito Público, Instituição de Educação Superior de Natureza Privada ou outra Fundação de Direito Privado

$\Rightarrow$ Anexo 2 - Anexo II - Requerimento de Outorga para Instituições de Educação Superior de Natureza Privada

$\rightarrow$ Anexo 3 - Anexo III - Requerimento de Outorga para as Fundações de Direito Privado

$\rightarrow$ Anexo 4 - Anexo IV - Requerimento de Renovação de Outorga para as Pessoas Jurídicas de Direito Público

$\Rightarrow$ Anexo 5 - Anexo V - Requerimento de Renovação de Outorga para as Instituições de Educação Superior de Natureza Privada

$\rightarrow$ Anexo 6 - Anexo VI - Requerimento de Renovação de Outorga para as Fundações de Direito Privado

$\rightarrow$ Anexo 7 - Anexo VII - Comunicação de Alteração de Quadro Diretivo/Societário

$\rightarrow$ Anexo 8 - Anexo VIII - Comunicação de Alteração Estatutária e Contratual

$\Rightarrow$ Anexo 9 - Anexo IX - Requerimento de Transferência de Outorga para as Pessoas Jurídicas de Direito Público

\section{Serviço de Retransmissão de Rádio (RTR)}

\section{Normatização}

Lei $n^{0}$ 13.649, de 11 de abril de 2018 - Dispõe sobre o Serviço de Retransmissão de Rádio (RTR) na Amazônia Legal

\section{Serviço de Retransmissão de Televisão (RTV)}

\section{Normatização}

Decreto $\mathbf{n}^{\mathbf{0}}$ 9.479, de 22 de agosto de 2018 - Altera o Regulamento do Serviço de Retransmissão de Televisão e do Serviço de Repetição de Televisão, ancilares ao Serviço de Radiodifusão de Sons e Imagens, aprovado pelo Decreto $\mathrm{n}^{\circ} 5.371$, de 17 de fevereiro de 2005.

Portaria MCTIC n ${ }^{0}$ 6.197, de 5 de dezembro de 2018 - Dispõe sobre o Serviço de Retransmissão de Televisão, ancilar ao Serviço de Radiodifusão de Sons e Imagens.

$\rightarrow$ Anexo 1 - Anexo I - Requerimento de Autorização para Execução do Serviço de Retransmissão de Televisão em Caráter Primário

$\Rightarrow$ Anexo 2 - Anexo II - Requerimento de Autorização para Execução do Serviço de Retransmissão de Televisão em Caráter Secundário

$\Rightarrow$ Anexo 3 - Anexo III - Requerimento de Transferência da Autorização 
Atos

Acórdão do Conselho Diretor da ANATEL, de 20 de dezembro de 2018 (Ref. $\mathbf{n}^{\circ}$ 726/2018) - Função pública de promoção da integração social por meio do acesso ao conteúdo de TV, mesmo que inscrita em lei estadual de criação de órgão da Administração Pública com dita competência, não se sobrepõe ao dever geral de obediência à prévia outorga do direito de uso de radiofrequência, de competência da União. Mora da Administração Pública federal na outorga do Serviço de Retransmissão de Televisão (RTV) e consequente uso não autorizado de radiofrequência na execução não outorgada do RTV não configuram atenuante ou excludente de ilicitude pela prática de infração de natureza grave, nos termos do art. 80 do Regulamento de Uso do Espectro de Radiofrequências (RUER/2001), aprovado pela Res. ANATEL n 259, de 19 de abril de 2001.

\section{Serviço de Repetição de Televisão (RpTV)}

\section{Normatização}

Decreto $\mathrm{n}^{\mathbf{0}}$ 9.479, de 22 de agosto de 2018 - Altera o Regulamento do Serviço de Retransmissão de Televisão e do Serviço de Repetição de Televisão, ancilares ao Serviço de Radiodifusão de Sons e Imagens, aprovado pelo Decreto ${ }^{\circ} 5.371$, de 17 de fevereiro de 2005.

\section{Serviço de Acesso Condicionado (SeAC)}

\section{Normatização}

Resolução da ANATEL no 692, de 12 de abril de 2018 - Altera o Regulamento do Serviço de Acesso Condicionado (SeAC), aprovado pela Resolução no 581, de 26 de março de 2012, e alterado pela Resolução no 618, de 24 de julho de 2013.

Resolução da ANATEL no 694, de 17 de julho de 2018 - Altera o Plano Geral de Metas de Competição - PGMC, aprovado pela Resolução n ${ }^{\circ} 600$, de 8 de novembro de 2012; o Regulamento de Remuneração pelo Uso de Redes de Prestadoras do Serviço Telefônico Fixo Comutado - STFC, aprovado pela Resolução $n^{\circ}$ 588, de 7 de maio de 2012; o Regulamento de Remuneração pelo Uso de Redes de Prestadoras do Serviço Móvel Pessoal - SMP, aprovado pela Resolução no 438, de 10 de julho de 2006; a Resolução n ${ }^{\circ} 396$, de 31 de março de 2005; o Regulamento de Aplicação de Sanções Administrativas, aprovado pela Resolução $\mathrm{n}^{\circ} 589$, de 7 de maio de 2012; revoga a Resolução n ${ }^{\circ} 437$, de 8 de junho de 2006; e dá outras providências.

$\rightarrow$ Anexo 1 - Anexo I - Diretrizes Metodológicas para Identificação de Mercado Relevante de Atacado e dos Grupos com PMS

- Anexo 2 - Anexo II - Mercados Relevantes e Medidas Regulatórias Assimétricas

$\rightarrow$ Anexo 3 - Anexo III - Homologação de Ofertas de Referência de Produtos de Atacado

$\rightarrow$ Anexo 4 - Anexo IV - Categorização dos Municípios

\section{Serviço de Comunicação Multimída (SCM)}

\section{Normatização}

Resolução da ANATEL no 694, de 17 de julho de 2018 - Altera o Plano Geral de Metas de Competição - PGMC, aprovado pela Resolução $n^{\circ}$ 600, de 8 de novembro de 2012; o Regulamento de Remuneração pelo Uso de Redes de Prestadoras do Serviço 
Telefônico Fixo Comutado - STFC, aprovado pela Resolução $n^{\circ}$ 588, de 7 de maio de 2012; o Regulamento de Remuneração pelo Uso de Redes de Prestadoras do Serviço Móvel Pessoal - SMP, aprovado pela Resolução no 438, de 10 de julho de 2006; a Resolução no 396, de 31 de março de 2005; o Regulamento de Aplicação de Sanções Administrativas, aprovado pela Resolução $\mathrm{n}^{\circ}$ 589, de 7 de maio de 2012; revoga a Resolução $n^{\circ} 437$, de 8 de junho de 2006; e dá outras providências.

$\Rightarrow$ Anexo 1 - Anexo I - Diretrizes Metodológicas para Identificação de Mercado Relevante de Atacado e dos Grupos com PMS

$\rightarrow$ Anexo 2 - Anexo II - Mercados Relevantes e Medidas Regulatórias Assimétricas

$\Rightarrow$ Anexo 3 - Anexo III - Homologação de Ofertas de Referência de Produtos de Atacado

Anexo 4 - Anexo IV - Categorização dos Municípios

Resolução da ANATEL $n^{0}$ 704, de 6 de novembro de 2018 - Altera o Regulamento de Gestão da Qualidade do Serviço de Comunicação Multimídia (RGQ-SCM), aprovado pela Resolução n ${ }^{\circ}$ 574, de 28 de outubro de 2011, o Regulamento de Gestão da Qualidade da Prestação do Serviço Móvel Pessoal (RGQ-SMP), aprovado pela Resolução nº 575, de 28 de outubro de 2011, o Regulamento de Gestão da Qualidade da Prestação do Serviço Telefônico Fixo Comutado (RGQ-STFC), aprovado pela Resolução $n^{\circ} 605$, de 26 de dezembro de 2012, o Regulamento do Serviço de Comunicação Multimídia, aprovado pela Resolução $n^{\circ}$ 614, de 28 de maio de 2013, e o Regulamento Geral de Direitos do Consumidor de Serviços de Telecomunicações - RGC, Resolução no 632, de 7 de março de 2014.

\section{Serviço Móvel Pessoal (SMP)}

\section{Normatização}

Portaria MCTIC no 3.045, de 7 de junho de 2018 - Dispõe sobre a destinação do saldo de recursos remanescente, proveniente da licitação de que trata o Edital n ${ }^{\circ} 2 / 2014$ SOR/SPR/CD-ANATEL, administrados pela Associação Administradora do Processo de Redistribuição e Digitalização de Canais de TV e RTV - EAD.

Resolução da ANATEL no 694, de 17 de julho de 2018 - Altera o Plano Geral de Metas de Competição - PGMC, aprovado pela Resolução n ${ }^{\circ}$ 600, de 8 de novembro de 2012; o Regulamento de Remuneração pelo Uso de Redes de Prestadoras do Serviço Telefônico Fixo Comutado - STFC, aprovado pela Resolução $\mathrm{n}^{\circ} 588$, de 7 de maio de 2012; o Regulamento de Remuneração pelo Uso de Redes de Prestadoras do Serviço Móvel Pessoal - SMP, aprovado pela Resolução no 438, de 10 de julho de 2006; a Resolução no 396, de 31 de março de 2005; o Regulamento de Aplicação de Sanções Administrativas, aprovado pela Resolução $\mathrm{n}^{\circ}$ 589, de 7 de maio de 2012; revoga a Resolução ${ }^{\circ} 437$, de 8 de junho de 2006; e dá outras providências.

$\rightarrow$ Anexo 1 - Anexo I - Diretrizes Metodológicas para Identificação de Mercado Relevante de Atacado e dos Grupos com PMS

$\Rightarrow$ Anexo 2 - Anexo II - Mercados Relevantes e Medidas Regulatórias Assimétricas

$\Rightarrow$ Anexo 3 - Anexo III - Homologação de Ofertas de Referência de Produtos de Atacado

$\rightarrow$ Anexo 4 - Anexo IV - Categorização dos Municípios

Resolução da ANATEL $\mathbf{n}^{\circ}$ 703, de $1^{\circ}$ de novembro de 2018 - Estabelece Limites Máximos de Quantidade de Espectro de Radiofrequências.

$\Rightarrow$ Anexo - Anexo - Tabelas de subfaixas de radiofrequência abaixo de $1 \mathrm{GHz}$ e entre $1 \mathrm{GHz}$ e $3 \mathrm{GHz}$ 
Resolução da ANATEL no 704, de 6 de novembro de 2018 - Altera o Regulamento de Gestão da Qualidade do Serviço de Comunicação Multimídia (RGQ-SCM), aprovado pela Resolução no 574, de 28 de outubro de 2011, o Regulamento de Gestão da Qualidade da Prestação do Serviço Móvel Pessoal (RGQ-SMP), aprovado pela Resolução nº 575 , de 28 de outubro de 2011, o Regulamento de Gestão da Qualidade da Prestação do Serviço Telefônico Fixo Comutado (RGQ-STFC), aprovado pela Resolução $n^{\circ} 605$, de 26 de dezembro de 2012, o Regulamento do Serviço de Comunicação Multimídia, aprovado pela Resolução n ${ }^{\circ}$ 614, de 28 de maio de 2013, e o Regulamento Geral de Direitos do Consumidor de Serviços de Telecomunicações - RGC, Resolução $n^{\circ} 632$, de 7 de março de 2014.

\section{Serviço Telefônico Fixo Comutado (STFC)}

\section{Jurisprudência}

Supremo Tribunal Federal - Ação Direta de Inconstitucionalidade no 4019 (STF ADI 4019 / SP - São Paulo) - Relator: Min. Luiz Fux - Plenário do STF - Unânime j. 13-12-2018 - Diário da Justiça, 05-02-2019. [Catalogação de Marcio Iorio Aranha ] $\checkmark$ Declarada a inconstitucionalidade da Lei $\mathrm{n}^{\circ} 12.155$, de 19 de dezembro de 2005, do Estado de São Paulo, que determinava a discriminação detalhada nas contas telefônicas das ligações locais.(Catalogado por: Márcio Iorio Ảranha).

\section{Normatização}

Decreto no 9.619, de 20 de dezembro de 2018 - Aprova o Plano Geral de Metas para a Universalização do Serviço Telefônico Fixo Comutado Prestado no Regime Público.

- Anexo 1 - Anexo I - Plano Geral de Metas para a Universalização do Serviço Telefônico Fixo Comutado Prestado no Regime Público

- Anexo 2 - Anexo II - Telefones de Uso Público das Concessionárias do Serviço Telefônico Fixo Comutado na Modalidade Local

$\Rightarrow$ Anexo 3 - Anexo III - Telefones de Uso Público das Concessionárias do Serviço Telefônico Fixo Comutado nas Modalidades Longa Distância Nacional e Internacional

$\rightarrow$ Anexo 4 - Anexo IV - Localidade a serem atendidades por Sistemas de Acesso Fixo sem Fio

Resolução da ANATEL no 699, de 28 de setembro de 2018 - Altera o Anexo II ao Regulamento sobre Áreas Locais para o Serviço Telefônico Fixo Comutado Destinado ao Uso do Público em Geral - STFC.

$\Rightarrow$ Anexo - Anexo - Alterações ao Anexo II do Regulamento sobre Áreas Locais para o Serviço Telefônico Fixo Comutado Destinado ao Uso do Público em Geral - STFC

Resolução da ANATEL no 701, de 5 de outubro de 2018 - Aprova alteração de Áreas de Tarifação do STFC e do Plano Geral de Códigos Nacionais - PGCN, para (...), aprova alteração de Áreas Locais para o STFC, para excluir o município de Rio NegroPR da Área Local de Curitiba e aprova alteração de tratamentos locais, em face das alterações anteriores.

$\Rightarrow$ Anexo 1 - Anexo I - Alteração das Áreas de Tarifação do STFC

$\rightarrow$ Anexo 2 - Anexo II - Alteração de Códigos Nacionais do PGCN

$\rightarrow$ Anexo 3 - Anexo III - Alteração de Áreas Locais do STFC

$\rightarrow$ Anexo 4 - Anexo IV - Exclusões, inclusão e alteração de Tratamentos Locais para o STFC

ARANHA, M.; LIMA, J.; QUELHO, R. Regulação do Setor de Telecomunicações em 2018. Revista de Direito, Estado e Telecomunicações, v. 11, n. 2, p. 177-230, outubro 2019.

DOI: https://doi.org/10.26512/1str.v11i2.27083 
Resolução da ANATEL no 704, de 6 de novembro de 2018 - Altera o Regulamento de Gestão da Qualidade do Serviço de Comunicação Multimídia (RGQ-SCM), aprovado pela Resolução n ${ }^{\circ}$ 574, de 28 de outubro de 2011, o Regulamento de Gestão da Qualidade da Prestação do Serviço Móvel Pessoal (RGQ-SMP), aprovado pela Resolução n ${ }^{\circ}$ 75, de 28 de outubro de 2011, o Regulamento de Gestão da Qualidade da Prestação do Serviço Telefônico Fixo Comutado (RGQ-STFC), aprovado pela Resolução $n^{\circ}$ 605, de 26 de dezembro de 2012, o Regulamento do Serviço de Comunicação Multimídia, aprovado pela Resolução $n^{\circ}$ 614, de 28 de maio de 2013, e o Regulamento Geral de Direitos do Consumidor de Serviços de Telecomunicações - RGC, Resolução ${ }^{\circ} 632$, de 7 de março de 2014.

\section{Ramos Jurídicos Afins}

\section{Direito Penal}

\section{- Direito Penal}

$\mathrm{O}$ art. $3^{\circ}$ do Regulamento de Aplicação de Sanções Administrativas prevê que as sanções nele dispostas são aplicáveis sem prejuízo das medidas previstas na legislação consumerista e das sanções de natureza civil e penal, inclusive a prevista pelo art.183 da Lei nº 9.472/1997.

\section{Normatização}

Lei $n^{0}$ 13.608, de 10 de janeiro de 2018 - Dispõe sobre o serviço telefônico de recebimento de denúncias e sobre recompensa por informações que auxiliem nas investigações policiais; e altera o art. 4o da Lei no 10.201, de 14 de fevereiro de 2001, para prover recursos do Fundo Nacional de Segurança Pública para esses fins.

\section{Direito Administrativo}

\section{Normatização}

Resolução da ANATEL no 691, de 22 de fevereiro de 2018 - Cria Centro de Altos Estudos em Telecomunicações - Ceatel e dá outras providências

\section{Aplicações de Telecomunicações}

\section{Aplicações Educacionais}

\section{Normatização}

Portaria MCTIC n⿳ 3.238, de 20 de junho de 2018 - Dispõe sobre permissão e concessão para execução dos serviços de radiodifusão sonora em frequência modulada e de sons e imagens, com fins exclusivamente educativos.

$\rightarrow$ Anexo 1 - Anexo I - Requerimento de Outorga para Pessoas Jurídicas de Direito Público

$\Rightarrow$ Anexo 10 - Anexo X - Requerimento de Transferência de Outorga para quando a Cedente for Instituição de Educação Superior de Natureza Privada e a Cessionária for Pessoa Jurídica de Direito Público ou outra Instituição de Educação Superior de Natureza Privada

$\rightarrow$ Anexo 11 - Anexo XI - Requerimento de Transferência de Outorga para quando a Cedente for Fundação de Direito Privado e a Cessionária for Pessoa Jurídica de ARANHA, M.; LIMA, J.; QUELHO, R. Regulação do Setor de Telecomunicações em 2018. Revista de Direito, Estado e Telecomunicações, v. 11, n. 2, p. 177-230, outubro 2019.

DOI: https://doi.org/10.26512/lstr.v11i2.27083 
Direito Público, Instituição de Educação Superior de Natureza Privada ou outra Fundação de Direito Privado

$\Rightarrow$ Anexo 2 - Anexo II - Requerimento de Outorga para Instituições de Educação Superior de Natureza Privada

$\rightarrow$ Anexo 3 - Anexo III - Requerimento de Outorga para as Fundações de Direito Privado

$\Rightarrow$ Anexo 4 - Anexo IV - Requerimento de Renovação de Outorga para as Pessoas Jurídicas de Direito Público

$\rightarrow$ Anexo 5 - Anexo V - Requerimento de Renovação de Outorga para as Instituições de Educação Superior de Natureza Privada

$\rightarrow$ Anexo 6 - Anexo VI - Requerimento de Renovação de Outorga para as Fundações de Direito Privado

$\Rightarrow$ Anexo 7 - Anexo VII - Comunicação de Alteração de Quadro Diretivo/Societário

- Anexo 8 - Anexo VIII - Comunicação de Alteração Estatutária e Contratual

$\rightarrow$ Anexo 9 - Anexo IX - Requerimento de Transferência de Outorga para as Pessoas Jurídicas de Direito Público

\section{Internet}

\section{Normatização}

Lei $\mathbf{n}^{\circ}$ 13.642, de 3 de abril de 2018 - Altera a Lei $n^{\circ} 10.446$, de 8 de maio de 2002, para acrescentar atribuição à Polícia Federal no que concerne à investigação de crimes praticados por meio da rede mundial de computadores que difundam conteúdo misógino, definidos como aqueles que propagam o ódio ou a aversão às mulheres.

Lei $\mathbf{n}^{\circ}$ 13.709, de 14 de agosto de 2018 [ (1) ] - Dispõe sobre a proteção de dados pessoais e altera a Lei $n^{\circ} 12.965$, de 23 de abril de 2014 (Marco Civil da Internet)

Medida Provisória no 869, de 27 de dezembro de 2018 - Altera a Lei no 13.709, de 14 de agosto de 2018, para dispor sobre a proteção de dados pessoais e para criar a Autoridade Nacional de Proteção de Dados, e dá outras providências.

Decreto $\mathrm{n}^{\mathbf{0}}$ 9.584, de 26 de novembro de 2018 - Altera o Decreto $\mathrm{n}^{\circ}$ 8.638, de 15 de janeiro de 2016, para instituir a Rede Nacional de Governo Digital.

Decreto $\mathbf{n}^{\circ}$ 9.637, de 26 de dezembro de 2018 - Institui a Política Nacional de Segurança da Informação, dispõe sobre a governança da segurança da informação, e altera o Decreto $\mathrm{n}^{\circ} 2.295$, de 4 de agosto de 1997, que regulamenta o disposto no art. 24, caput, inciso IX, da Lei $n^{\circ} 8.666$, de 21 de junho de 1993, e dispõe sobre a dispensa de licitação nos casos que possam comprometer a segurança nacional.

\section{Banda Larga}

\section{Normatização}

Decreto $n^{\mathbf{0}}$ 9.584, de 26 de novembro de 2018 - Altera o Decreto ${ }^{\circ} 8.638$, de 15 de janeiro de 2016, para instituir a Rede Nacional de Governo Digital.

Decreto $n^{0}$ 9.637, de 26 de dezembro de 2018 - Institui a Política Nacional de Segurança da Informação, dispõe sobre a governança da segurança da informação, e altera o Decreto $\mathrm{n}^{\circ} 2.295$, de 4 de agosto de 1997, que regulamenta o disposto no art. 
24, caput, inciso IX, da Lei no 8.666, de 21 de junho de 1993, e dispõe sobre a dispensa de licitação nos casos que possam comprometer a segurança nacional.

\section{Governança Digital}

\section{Normatização}

Decreto $\mathrm{n}^{\mathbf{0}}$ 9.584, de 26 de novembro de 2018 - Altera o Decreto $\mathrm{n}^{\circ} 8.638$, de 15 de janeiro de 2016, para instituir a Rede Nacional de Governo Digital.

\section{Atores no Setor de Telecomunicações}

\section{ANATEL}

\section{Normatização}

Decreto $\mathbf{n}^{0}$ 9.507, de 21 de setembro de 2018 - Dispõe sobre a execução indireta, mediante contratação, de serviços da administração pública federal direta, autárquica e fundacional e das empresas públicas e das sociedades de economia mista controladas pela União.

Resolução da ANATEL no 691, de 22 de fevereiro de 2018 - Cria Centro de Altos Estudos em Telecomunicações - Ceatel e dá outras providências

Resolução da ANATEL $n^{\circ}$ 696, de 23 de julho de 2018 - Revoga a Resolução ${ }^{\circ}$ 530, de 10 de junho de 2009, que autoriza valores para aquisição ou alienação de bens móveis e imóveis e para a contratação de obras e serviços de terceiros.

Resolução da ANATEL n 698, de 27 de setembro de 2018 - Institui o Comitê de Prestadoras de Pequeno Porte de Serviços de Telecomunicações junto à Anatel e aprova seu Regimento Interno.

$\Rightarrow$ Anexo - Anexo - Regimento Interno do Comitê de Prestadoras de Pequeno Porte de Serviços de Telecomunicações junto à ANATEL

\section{Poder Executivo}

\section{Presidência da República}

\section{Normatização}

Decreto $\mathbf{n}^{0}$ 9.619, de 20 de dezembro de 2018 - Aprova o Plano Geral de Metas para a Universalização do Serviço Telefônico Fixo Comutado Prestado no Regime Público.

$\rightarrow$ Anexo 1 - Anexo I - Plano Geral de Metas para a Universalização do Serviço Telefônico Fixo Comutado Prestado no Regime Público

$\Rightarrow$ Anexo 2 - Anexo II - Telefones de Uso Público das Concessionárias do Serviço Telefônico Fixo Comutado na Modalidade Local

$\rightarrow$ Anexo 3 - Anexo III - Telefones de Uso Público das Concessionárias do Serviço Telefônico Fixo Comutado nas Modalidades Longa Distância Nacional e Internacional

Anexo 4 - Anexo IV - Localidade a serem atendidades por Sistemas de Acesso Fixo sem Fio

\section{Ministério da Ciência, Tecnologia, Inovações e Comunicações}

Tema Conexo: Serviços no Setor de Telecomunicações : Radiodifusão.

ARANHA, M.; LIMA, J.; QUELHO, R. Regulação do Setor de Telecomunicações em 2018. Revista de Direito, 


\section{Normatização}

Decreto $n^{\circ}$ 9.319, de 21 de março de 2018 - Institui o Sistema Nacional para a Transformação Digital e estabelece a estrutura de governança para a implantação da Estratégia Brasileira para a Transformação Digital.

$\rightarrow$ Anexo 1 - Anexo I - Eixos Temáticos da Estratégia Brasileira para a Transformação Digital - E-Digital

\section{$\rightarrow$ Anexo 2}

\section{Ministério do Planejamento, Orçamento e Gestão}

\section{Normatização}

Decreto $\mathbf{n}^{\mathbf{0}}$ 9.584, de 26 de novembro de 2018 - Altera o Decreto $n^{\circ} 8.638$, de 15 de janeiro de 2016, para instituir a Rede Nacional de Governo Digital.

\section{Poder Judiciário}

\section{STF}

\section{Jurisprudência}

4. Supremo Tribunal Federal - Ação Direta de Inconstitucionalidade $n^{\circ} 4019$ (STF ADI 4019 / SP - São Paulo) - Relator: Min. Luiz Fux - Plenário do STF - Unânime j. 13-12-2018 - Diário da Justiça, 05-02-2019. [Catalogação de Marcio Iorio Aranha ]

$\checkmark$ Declarada a inconstitucionalidade da Lei $n^{\circ} 12.155$, de 19 de dezembro de 2005, do Estado de São Paulo, que determinava a discriminação detalhada nas contas telefônicas das ligações locais.(Catalogado por: Márcio Iorio Aranha).

\section{Prestadora / Operadora}

\section{Normatização}

Resolução da ANATEL n $^{0}$ 698, de 27 de setembro de 2018 - Institui o Comitê de Prestadoras de Pequeno Porte de Serviços de Telecomunicações junto à Anatel e aprova seu Regimento Interno.

$\Rightarrow$ Anexo - Anexo - Regimento Interno do Comitê de Prestadoras de Pequeno Porte de Serviços de Telecomunicações junto à ANATEL

\section{Atos}

Acórdão do Conselho Diretor da ANATEL, de 3 de janeiro de 2018 (Ref. $\mathrm{n}^{0} 11 / 2018$ ) - Não há direito à supensão de processos administrativos por descumprimento de obrigações afetas à prestadora de serviços de telecomunicações em recuperação judicial.

\section{Usuário / Consumidor}

\section{Normatização}

Lei $n^{\mathbf{0}}$ 13.673, de 5 de junho de 2018 - Altera as Leis $n^{\circ}$ s 8.987, de 13 de fevereiro de $1995,9.427$, de 26 de dezembro de 1996, e 9.472, de 16 de julho de 1997, para tornar obrigatória a divulgação de tabela com a evolução do valor da tarifa e do preço praticados pelas concessionárias e prestadoras de serviços públicos. 
Lei $\mathrm{n}^{\circ}$ 13.726, de 8 de outubro de 2018 - Racionaliza atos e procedimentos administrativos dos Poderes da União, dos Estados, do Distrito Federal e dos Municípios e institui o Selo de Desburocratização e Simplificação.

\section{Estado-Membro}

\section{Jurisprudência}

Supremo Tribunal Federal - Ação Direta de Inconstitucionalidade no 4019 (STF ADI 4019 / SP - São Paulo) - Relator: Min. Luiz Fux - Plenário do STF - Unânime j. 13-12-2018 - Diário da Justiça, 05-02-2019. [Catalogação de Marcio Iorio Aranha ] $\checkmark$ Declarada a inconstitucionalidade da Lei $\mathrm{n}^{\circ} 12.155$, de 19 de dezembro de 2005, do Estado de São Paulo, que determinava a discriminação detalhada nas contas telefônicas das ligações locais.(Catalogado por: Márcio Iorio Aranha).

\section{Normas Referenciadas}

\section{Lei Ordinária}

Lei $\mathrm{n}^{\circ}$ 13.608, de 10 de janeiro de 2018 - Dispõe sobre o serviço telefônico de recebimento de denúncias e sobre recompensa por informações que auxiliem nas investigações policiais; e altera o art. 4o da Lei no 10.201, de 14 de fevereiro de 2001, para prover recursos do Fundo Nacional de Segurança Pública para esses fins.

\begin{tabular}{|l|l|}
\hline Nota Vigência & Data de publicação no DOU. \\
\hline Dispositivos & CF, Art. $5^{\circ}$, inciso X; LGT, Art. $3^{\circ}$, inciso V. \\
\hline Altera & Lei $n^{\circ} 10.201 / 2001$ \\
\hline Publicação & Diário Oficial da União, Seção $1,11 / 01 / 2018$, pág. p. 1 \\
\hline Temas & $\begin{array}{l}\text { Temas : Fundamentos : Conceitos Fundamentais : Direito à Privacidade } \\
\text { Temas : Ramos Jurídicos Afins : Direito Penal }\end{array}$ \\
\hline
\end{tabular}

Lei $\mathbf{n}^{0}$ 13.642, de 3 de abril de 2018 - Altera a Lei $\mathrm{n}^{\circ}$ 10.446, de 8 de maio de 2002, para acrescentar atribuição à Polícia Federal no que concerne à investigação de crimes praticados por meio da rede mundial de computadores que difundam conteúdo misógino, definidos como aqueles que propagam o ódio ou a aversão às mulheres.

\begin{tabular}{|l|l|}
\hline Nota Vigência & Data de publicação no DOU. \\
\hline Dispositivos & LGT, Art. 61, caput. \\
\hline Regulamenta & Lei no 10.446, de 8 de maio de 2002 \\
\hline Publicação & Diário Oficial da União, Seção 1, 04/04/2018, pág. p. 1 \\
\hline Temas & $\begin{array}{l}\text { Temas : Aplicações de Telecomunicações : Internet } \\
\text { Temas : Serviços no Setor de Telecomunicações : Internet }\end{array}$ \\
\hline
\end{tabular}

Lei n⿳ 13.644, de 4 de abril de 2018 - Altera a Lei n ${ }^{\circ}$ 4.117, de 27 de agosto de 1962, para dispor sobre o horário de retransmissão obrigatória do programa oficial dos Poderes da República pelas emissoras de radiodifusão sonora.

\begin{tabular}{|l|l|}
\hline Nota Vigência & Data de publicação no DOU. \\
\hline Dispositivos & CF, Art. 21, inciso XII, alínea a (em 15/08/1995); CF, Art. 22, inciso IV; LGT, Art. 211, caput. \\
\hline Altera & Lei n ${ }^{\circ} 4.117 / 1962$ - Institui o Código Brasileiro de Telecomunicações. \\
\hline Publicação & Diário Oficial da União, Seção 1, 05-04-2018, pág. p. 1 \\
\hline
\end{tabular}


\begin{tabular}{|l|l}
\hline Temas & Temas : Serviços no Setor de Telecomunicações : Radiodifusão \\
\hline
\end{tabular}

\begin{tabular}{|l|l|}
\hline $\begin{array}{l}\text { Lei no 13.649, de } 11 \text { de abril de } 2018 \text { - Dispõe sobre o Serviço de Retransmissão de Rádio (RTR) na Amazônia } \\
\text { Legal }\end{array}$ \\
\hline Nota Vigência & Data de publicação no DOU \\
\hline Dispositivos & $\begin{array}{l}\text { CF, Art. 21, inciso XII, alínea a (em 15/08/1995); CF, Art. 22, inciso IV; LGT, Art. 47, caput; } \\
\text { LGT, Art. 211, caput. }\end{array}$ \\
\hline Altera & Anexo à Lei no 5.070, de 7 de julho de 1966 - Valores das Taxas de Fiscalização de Instalação. \\
\hline Publicação & Diário Oficial da União, Seção 1, 12-04-2018, pág. p.1 \\
\hline Temas & $\begin{array}{l}\text { Temas : Serviços no Setor de Telecomunicações : Radiodifusão : Serviço de Retransmissão de } \\
\text { Rádio (RTR) }\end{array}$ \\
\hline
\end{tabular}

Lei $\mathbf{n}^{\circ}$ 13.673, de 5 de junho de 2018 - Altera as Leis $n^{\circ}$ s 8.987, de 13 de fevereiro de 1995, 9.427, de 26 de dezembro de 1996, e 9.472, de 16 de julho de 1997, para tornar obrigatória a divulgação de tabela com a evolução do valor da tarifa e do preço praticados pelas concessionárias e prestadoras de serviços públicos.

\begin{tabular}{|l|l|}
\hline Nota Vigência & Data de publicação no DOU. \\
\hline Dispositivos & CF, Art. 175, § único, inciso II. \\
\hline Altera & $\begin{array}{l}\text { Lei no } 8.987 / 1995 \text { - Dispõe sobre o regime de concessão e permissão da prestação de serviços } \\
\text { públicos previsto no artigo } 175 \text { da Constituição Federal, e dá outras providências. } \\
\text { Lei no 9.427/1996 } \\
\text { Lei no 9.472/1997 - Dispõe sobre a organização dos serviços de telecomunicações, a criação e } \\
\text { funcionamento de um órgão regulador e outros aspectos institucionais, nos termos da Emenda } \\
\text { Constitucional no 8, de 1995. }\end{array}$ \\
\hline Publicação & Diário Oficial da União, Seção 1, 06-12-2018, pág. p. 2 \\
\hline Temas & Temas : Atores no Setor de Telecomunicações : Usuário / Consumidor \\
\hline
\end{tabular}

Lei $\mathrm{n}^{\circ}$ 13.709, de 14 de agosto de 2018 - Dispõe sobre a proteção de dados pessoais e altera a Lei $\mathrm{n}^{\circ} 12.965$, de 23 de abril de 2014 (Marco Civil da Internet)

\begin{tabular}{|c|c|}
\hline Nota Vigência & Entrada em vigor após 18 meses da publicação. \\
\hline Dispositivos & CF, Art. 5o, inciso IV; CF, Art. 5, inciso IX; CF, Art 5, inciso X; LGT, Art. 61, caput. \\
\hline Altera & $\begin{array}{l}\text { Lei n }{ }^{\circ} 12.965 / 2014 \text { - Estabelece princípios, garantias, direitos e deveres para o uso da Internet } \\
\text { no Brasil. }\end{array}$ \\
\hline Alterada por & $\begin{array}{l}\text { Medida Provisória }{ }^{\circ} 869 / 2018 \text { - Altera a Lei } \mathrm{n}^{\circ} 13.709 \text {, de } 14 \text { de agosto de } 2018 \text {, para dispor } \\
\text { sobre a proteção de dados pessoais e para criar a Autoridade Nacional de Proteção de Dados, e } \\
\text { dá outras providências. }\end{array}$ \\
\hline Correlata & $\begin{array}{l}\text { Lei }{ }^{\circ} 9.394 / 1996 \text { - Estabelece as diretrizes e bases da educação nacional. } \\
\text { Lei } 10.861 \text {, de } 14 \text { de abril de } 2004\end{array}$ \\
\hline Publicação & Diário Oficial da União, Seção 1, 15-08-2018, pág. p. 59 \\
\hline Temas & $\begin{array}{l}\text { Temas : Aplicações de Telecomunicações : Internet } \\
\text { Temas : Serviços no Setor de Telecomunicações : Internet }\end{array}$ \\
\hline
\end{tabular}

\begin{tabular}{|l|l|}
\hline $\begin{array}{l}\text { Lei no 13.726, de } 8 \text { de outubro de } 2018 \text { - Racionaliza atos e procedimentos administrativos dos Poderes da } \\
\text { União, dos Estados, do Distrito Federal e dos Municípios e institui o Selo de Desburocratização e Simplificação. }\end{array}$ \\
\hline Nota Vigência & 45 dias após sua publicação. \\
\hline Dispositivos & LGT, Art. 3ㅜ, caput. \\
\hline Publicação & Diário Oficial da União, Seção 1,09-10-2018, pág. p.1 \\
\hline Temas & Temas : Atores no Setor de Telecomunicações : Usuário / Consumidor \\
\hline
\end{tabular}

ARANHA, M.; LIMA, J.; QUELHO, R. Regulação do Setor de Telecomunicações em 2018. Revista de Direito, Estado e Telecomunicações, v. 11, n. 2, p. 177-230, outubro 2019.

DOI: https://doi.org/10.26512/lstr.v11i2.27083 


\section{Medida Provisória}

\begin{tabular}{|c|c|}
\hline $\begin{array}{l}\text { Medida Provi } \\
\text { dispor sobre a } \\
\text { providências. }\end{array}$ & $\begin{array}{l}\text { sória } \mathbf{~ n}^{\mathbf{0}} \mathbf{8 6 9} \text {, de } 27 \text { de dezembro de } \mathbf{2 0 1 8} \text { - Altera a Lei no } 13.709 \text {, de } 14 \text { de agosto de } 2018 \text {, para } \\
\text { proteção de dados pessoais e para criar a Autoridade Nacional de Proteção de Dados, e dá outras }\end{array}$ \\
\hline Nota Vigência & Entrada em vigor após 18 meses da publicação. \\
\hline Dispositivos & CF, Art. 5, inciso IV; CF, Art. 5', inciso IX; CF, Art 5', inciso X; LGT, Art. 61, caput. \\
\hline Altera & $\begin{array}{l}\text { Lei } \mathrm{n}^{\circ} 13.502 \text {, de } 1^{\circ} \text { de novembro de } 2017 \\
\text { Lei } \mathrm{n}^{\circ} 13.709 / 2018 \text { - Dispõe sobre a proteção de dados pessoais e altera a Lei } \mathrm{n}^{\circ} 12.965 \text {, de } 23 \\
\text { de abril de } 2014 \text { (Marco Civil da Internet) }\end{array}$ \\
\hline Correlata & $\begin{array}{l}\text { Lei } \mathrm{n}^{\circ} \text { 9.394/1996 - Estabelece as diretrizes e bases da educação nacional. } \\
\text { Lei } 10.861 \text {, de } 14 \text { de abril de } 2004\end{array}$ \\
\hline Publicação & Diário Oficial da União, Seção 1, 28-12-2018, págs. p. 8-9. \\
\hline Temas & $\begin{array}{l}\text { Temas : Aplicações de Telecomunicações : Internet } \\
\text { Temas : Serviços no Setor de Telecomunicações : Internet }\end{array}$ \\
\hline
\end{tabular}

\section{Decreto}

Decreto $\mathrm{n}^{\mathbf{0}}$ 9.270, de 25 de janeiro de 2018 - Fixa prazo para manifestação de interesse na adaptação de outorga do serviço de radiodifusão sonora em onda média, de caráter local, regional e nacional, para a execução do serviço de radiodifusão em frequência modulada.

\begin{tabular}{|l|l|}
\hline Nota Vigência & Data de publicação no DOU. \\
\hline Dispositivos & CF, Art. 21, inciso XII, alínea a (em 15/08/1995); LGT, Art. 211, caput. \\
\hline Altera & $\begin{array}{l}\text { Decreto } n^{\circ} \text { 8139/2013 - Dispõe sobre as condições para extinção do serviço de radiodifusão } \\
\text { sonora em ondas médias de caráter local, sobre a adaptação das outorgas vigentes para execução } \\
\text { deste serviço e dá outras providências. }\end{array}$ \\
\hline Correlata & Decreto ${ }^{\circ}$ 52.795/1963 - Aprova o Regulamento dos Serviços de Radiodifusão. \\
\hline Regulamenta & Lei no 4.117/1962 - Institui o Código Brasileiro de Telecomunicações. \\
\hline Publicação & Diário Oficial da União, 26-01-2018, pág. p. 1 \\
\hline Temas & Temas : Serviços no Setor de Telecomunicações : Radiodifusão \\
\hline
\end{tabular}

Decreto n $^{0}$ 9.319, de 21 de março de 2018 - Institui o Sistema Nacional para a Transformação Digital e estabelece a estrutura de governança para a implantação da Estratégia Brasileira para a Transformação Digital.

\begin{tabular}{|c|c|}
\hline Nota Vigência & Data de publicação no DOU \\
\hline Anexos & $\begin{array}{l}\text { Anexo } 1 \text { - Anexo I - Eixos Temáticos da Estratégia Brasileira para a Transformação Digital - } \\
\text { E-Digital } \\
\text { Anexo } 2\end{array}$ \\
\hline Dispositivos & LGT, Art. $1^{\circ}$, caput. \\
\hline Altera & $\begin{array}{l}\text { Anexo I ao Decreto } n^{\circ} 8.877 \text {, de } 18 \text { de outubro de } 2016 \text { - Anexo I ao Decreto } n^{\circ} 8.877 \text {, de } 18 \text { de } \\
\text { outubro de } 2016 \\
\text { Anexo II ao Decreto } n^{\circ} 8.877 \text {, de } 18 \text { de outubro de } 2016 \text { - Anexo II ao Decreto } n^{\circ} 8.877 \text {, de } 18 \\
\text { de outubro de } 2016\end{array}$ \\
\hline Correlata & $\begin{array}{l}\text { Decreto }{ }^{\circ} 8.638 \text {, de } 15 \text { de janeiro de } 2016 \text { - Institui a Política de Governança Digital no âmbito } \\
\text { dos órgãos e das entidades da administração pública federal direta, autárquica e fundacional. } \\
\text { Decreto } n^{\circ} 9.584 / 2018 \text { - Altera o Decreto } n^{\circ} 8.638 \text {, de } 15 \text { de janeiro de } 2016 \text {, para instituir a } \\
\text { Rede Nacional de Governo Digital. }\end{array}$ \\
\hline Publicação & Diário Oficial da União, Seção 1, 22-03-2018, pág. p. 2 \\
\hline Temas & Jes : Poder Executivo : Ministério das Com \\
\hline
\end{tabular}

ARANHA, M.; LIMA, J.; QUELHO, R. Regulação do Setor de Telecomunicações em 2018. Revista de Direito, Estado e Telecomunicações, v. 11, n. 2, p. 177-230, outubro 2019.

DOI: https://doi.org/10.26512/lstr.v11i2.27083 
Temas : Políticas de Telecomunicações

\begin{tabular}{|c|c|}
\hline \multicolumn{2}{|c|}{$\begin{array}{l}\text { Decreto } \mathbf{n}^{\circ} \text { 9.479, de } 22 \text { de agosto de } \mathbf{2 0 1 8} \text { - Altera o Regulamento do Serviço de Retransmissão de Televisão } \\
\text { e do Serviço de Repetição de Televisão, ancilares ao Serviço de Radiodifusão de Sons e Imagens, aprovado } \\
\text { pelo Decreto } n^{\circ} 5.371 \text {, de } 17 \text { de fevereiro de } 2005 \text {. }\end{array}$} \\
\hline Nota Vigência & $\begin{array}{l}\text { Vigência do art. } 1^{\circ} \text {, na parte que altera os art. } 13 \text {, art. } 14 \text {, art. } 14-\mathrm{A} \text {, art. } 14-\mathrm{B} \text {, art. } 14-\mathrm{C} \text { e art. } 14- \\
\text { D do Regulamento do Serviço de Retransmissão de Televisão e do Serviço de Repetição de } \\
\text { Televisão, ancilares ao Serviço de Radiodifusão de Sons e Imagens, aprovado pelo Decreto }{ }^{\circ} \\
5.371 \text {, de } 2005 \text {, diferida para } 10 \text { de dezembro de } 2018 \text {. }\end{array}$ \\
\hline Dispositivos & CF, Art. 21, inciso XII, alínea a (em 15/08/1995); LGT, Art. 211, caput. \\
\hline Altera & $\begin{array}{l}\text { Decreto }{ }^{\circ} \text { 5.371/2005 - Aprova o Regulamento do Serviço de Retransmissão de Televisão e do } \\
\text { Serviço de Repetição de Televisão, ancilares ao Serviço de Radiodifusão de Sons e Imagens. } \\
\text { Anexo ao Decreto n } n^{\circ} \text { 5.371, de } 17 \text { de fevereiro de } 2005 \text { - Regulamento do Serviço de } \\
\text { Retransmissão de Televisão e do Serviço de Repetição de Televisão, ancilares ao Serviço de } \\
\text { Radiodifusão de Sons e Imagens. }\end{array}$ \\
\hline Regulamenta & Lei nº 4.117/1962 - Institui o Código Brasileiro de Telecomunicações. \\
\hline $\begin{array}{l}\text { Regulamentada } \\
\text { por }\end{array}$ & $\begin{array}{l}\text { Portaria MCTIC n }{ }^{\circ} 6.197 \text {, de } 5 \text { de dezembro de } 2018 \text { - Dispõe sobre o Serviço de Retransmissão } \\
\text { de Televisão, ancilar ao Serviço de Radiodifusão de Sons e Imagens. }\end{array}$ \\
\hline Publicação & Diário Oficial da União, Seção 1, 23-08-2018, pág. p. 2 \\
\hline Temas & $\begin{array}{l}\text { Temas : Serviços no Setor de Telecomunicações : Radiodifusão : Serviço Especial de Repetição } \\
\text { de Televisão (RpTV) } \\
\text { Temas : Serviços no Setor de Telecomunicações : Radiodifusão : Serviço de Retransmissão de } \\
\text { Televisão (RTV) }\end{array}$ \\
\hline
\end{tabular}

Decreto $\mathbf{n}^{0}$ 9.507, de 21 de setembro de 2018 - Dispõe sobre a execução indireta, mediante contratação, de serviços da administração pública federal direta, autárquica e fundacional e das empresas públicas e das sociedades de economia mista controladas pela União.

\begin{tabular}{|c|c|}
\hline Nota Vigência & 180 dias após publicação no DOU \\
\hline Dispositivos & LGT, Art. $1^{\circ}$, caput; LGT, Art. 19 , caput. \\
\hline Altera & Decreto $\mathrm{n}^{\circ} 99.188$, de 17 de março de 1990 \\
\hline Revoga & $\begin{array}{l}\text { Decreto } \mathrm{n}^{\circ} 2.031 \text {, de } 11 \text { de outubro de } 1996 \\
\text { Decreto }^{\circ} 2.271 \text {, de } 7 \text { de julho de } 1997\end{array}$ \\
\hline Regulamenta & $\begin{array}{l}\text { Lei n }{ }^{\circ} 8.666 / 93 \text { - Regulamenta o artigo 37, inciso XXI, da Constituição Federal, institui normas } \\
\text { para licitações e contratos da Administração Pública e dá outras providências. } \\
\text { Decreto-Lei nº 200/1967 }\end{array}$ \\
\hline Publicação & Diário Oficial da União, Seção 1, 24-09-2018, pág. p. 3 \\
\hline Temas & $\begin{array}{l}\text { Temas : Administração do Setor de Telecomunicações } \\
\text { Temas : Atores no Setor de Telecomunicações : ANATEL }\end{array}$ \\
\hline
\end{tabular}

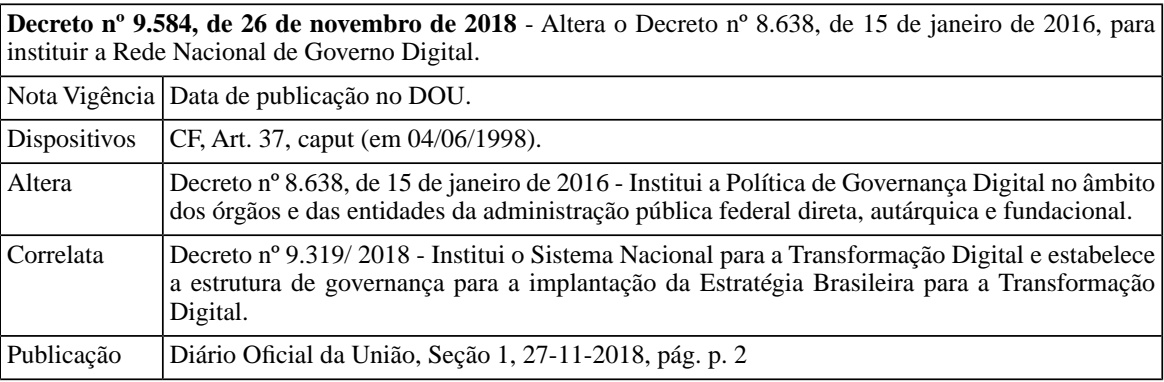

ARANHA, M.; LIMA, J.; QUELHO, R. Regulação do Setor de Telecomunicações em 2018. Revista de Direito, Estado e Telecomunicações, v. 11, n. 2, p. 177-230, outubro 2019.

DOI: https://doi.org/10.26512/lstr.v11i2.27083 


\begin{tabular}{|l|l|}
\hline Temas & Temas : Aplicações de Telecomunicações : Banda Larga \\
& Temas : Aplicações de Telecomunicações : Governança Digital \\
& Temas : Aplicações de Telecomunicações : Internet \\
& Temas : Atores no Setor de Telecomunicações : Poder Executivo : Ministério do Planejamento \\
& Orçamento e Gestão \\
& Temas : Serviços no Setor de Telecomunicações : Internet \\
\hline
\end{tabular}

\begin{tabular}{|c|c|}
\hline \multicolumn{2}{|c|}{ Decreto no 9.612, de 17 de dezembro de 2018 - Dispõe sobre políticas públicas de telecomunicações. } \\
\hline Nota Vigência & Data de publicação no DOU. \\
\hline Dispositivos & CF, Art. 21, inciso XI (em 15/08/1995); LGT, Art. $1^{\circ}$, caput; LGT, Art. 19, inciso I. \\
\hline Revoga & $\begin{array}{l}\text { Decreto } \mathrm{n}^{\circ} 4.733 / 2003 \text { - Dispõe sobre políticas públicas de telecomunicações, e dá outras } \\
\text { providências. } \\
\text { Decreto } \mathrm{n}^{\circ} 7.175 / 2010 \text { - Institui o Programa Nacional de Banda Larga - PNBL; dispõe sobre } \\
\text { remanejamento de cargos em comissão; altera o Anexo II ao Decreto no 6.188, de } 17 \text { de agosto } \\
\text { de } 2007 \text {; altera e acresce dispositivos ao Decreto no 6.948, de } 25 \text { de agosto de 2009; e dá outras } \\
\text { providências. - Anexo - Quadro demonstrativo dos cargos em comissão e Quadro resumo dos } \\
\text { custos dos cargos em comissão do Gabinete Pessoal do Presidente da República. } \\
\text { Decreto } n^{\circ} 8.776 \text {, de } 11 \text { de maio de } 2016\end{array}$ \\
\hline Regulamenta & $\begin{array}{l}\text { Lei } n^{\circ} 9.472 / 1997 \text { - Dispõe sobre a organização dos serviços de telecomunicações, a criação e } \\
\text { funcionamento de um órgão regulador e outros aspectos institucionais, nos termos da Emenda } \\
\text { Constitucional } n^{\circ} 8 \text {, de } 1995 \text {. } \\
\text { Lei no } 10.052 / 2000 \text { - Institui o Fundo para o Desenvolvimento Tecnológico das Telecomunicações } \\
\text { - Funttel, e dá outras providências. }\end{array}$ \\
\hline Publicação & Diário Oficial da União, Seção 1, 18-12-2018, pág. p. 18 \\
\hline Temas & $\begin{array}{l}\text { Temas : Infraestrutura e Recursos do Setor de Telecomunicações : Infra-estrutura de } \\
\text { Telecomunicações : Compartilhamento de Infraestrutura } \\
\text { Temas : Políticas de Telecomunicações }\end{array}$ \\
\hline
\end{tabular}

Decreto $\mathrm{n}^{\circ}$ 9.619, de 20 de dezembro de 2018 - Aprova o Plano Geral de Metas para a Universalização do Serviço Telefônico Fixo Comutado Prestado no Regime Público.

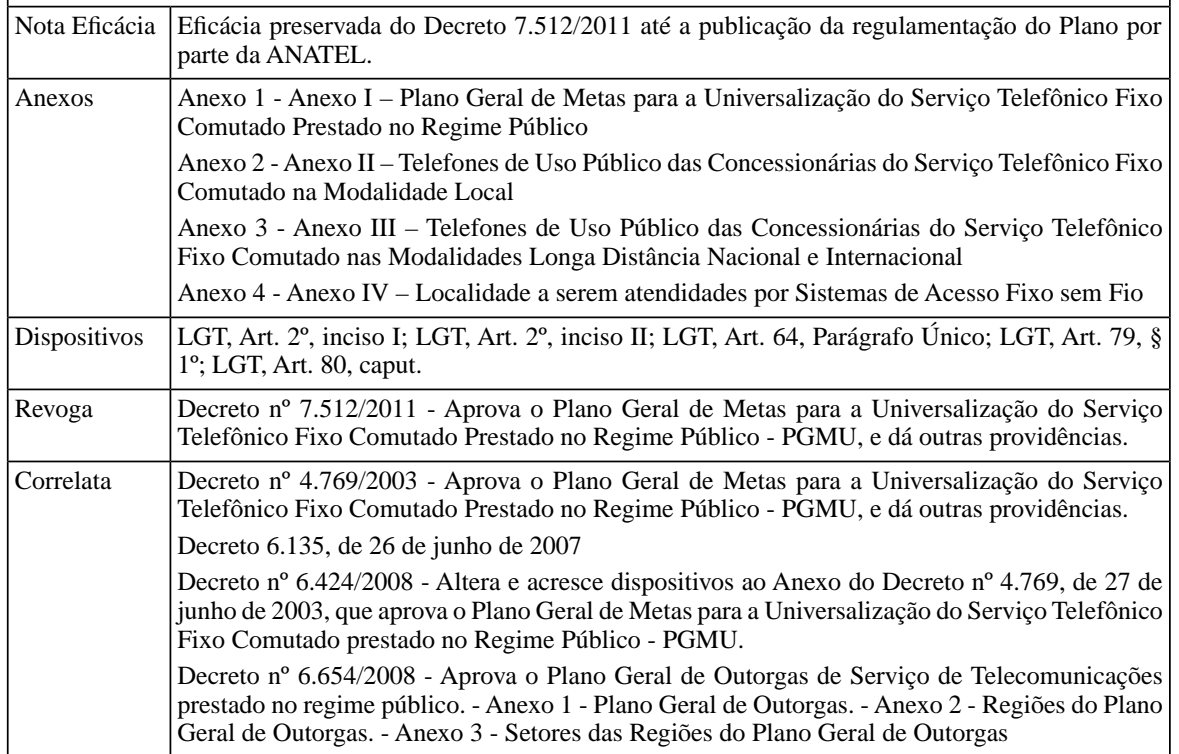

ARANHA, M.; LIMA, J.; QUELHO, R. Regulação do Setor de Telecomunicações em 2018. Revista de Direito, Estado e Telecomunicações, v. 11, n. 2, p. 177-230, outubro 2019.

DOI: https://doi.org/10.26512/lstr.v11i2.27083 


\begin{tabular}{|l|l|}
\hline Regulamenta & $\begin{array}{l}\text { Lei no 9.472/1997 - Dispõe sobre a organização dos serviços de telecomunicações, a criação e } \\
\text { funcionamento de um órgão regulador e outros aspectos institucionais, nos termos da Emenda } \\
\text { Constitucional n 8, de 1995. }\end{array}$ \\
\hline Publicação & $\begin{array}{l}\text { Diário Oficial da União, Seção 1, 27-12-2018, pág. p. 8. } \\
\text { Diário Oficial da União, Seção 1, 27-12-2018 [ Retificação ] }\end{array}$ \\
\hline Temas & $\begin{array}{l}\text { Temas : Administração do Setor de Telecomunicações : Outorgas : Concessão (regras aplicáveis) } \\
\text { Temas : Atores no Setor de Telecomunicações : Poder Executivo : Presidência da República } \\
\text { Temas : Políticas de Telecomunicações : Universalização : Metas de Universalização } \\
\text { Temas : Serviços no Setor de Telecomunicações : Serviço Telefônico Fixo Comutado (STFC) }\end{array}$ \\
\hline
\end{tabular}

Decreto $\mathbf{n}^{0}$ 9.637, de 26 de dezembro de 2018 - Institui a Política Nacional de Segurança da Informação, dispõe sobre a governança da segurança da informação, e altera o Decreto $\mathrm{n}^{\circ} 2.295$, de 4 de agosto de 1997 , que regulamenta o disposto no art. 24, caput, inciso IX, da Lei $n^{\circ} 8.666$, de 21 de junho de 1993, e dispõe sobre a dispensa de licitação nos casos que possam comprometer a segurança nacional.

\begin{tabular}{|c|c|}
\hline Nota Vigência & Data de publicação no DOU. \\
\hline Dispositivos & $\mathrm{CF}$, Art $5^{\circ}$, inciso XIV; LGT, Art. $1^{\circ}$, caput. \\
\hline Altera & Decreto $\mathrm{n}^{\circ} 2.295$, de 4 de agosto de 1997 \\
\hline Revoga & $\begin{array}{l}\text { Decreto } 3.505 \text {, de } 13 \text { de junho de } 2000 \\
\text { Decreto } \mathrm{n}^{\circ} 8.135 \text {, de } 4 \text { de novembro de } 2013 \text { - Dispõe sobre as comunicações de dados da } \\
\text { administração pública federal direta, autárquica e fundacional, e sobre a dispensa de licitação } \\
\text { nas contratações que possam comprometer a segurança nacional. }\end{array}$ \\
\hline Publicação & Diário Oficial da União, Seção 1, 27-12-2018, págs. p. 23-25 \\
\hline Temas & $\begin{array}{l}\text { Temas : Aplicações de Telecomunicações : Banda Larga } \\
\text { Temas : Aplicações de Telecomunicações : Internet } \\
\text { Temas : Fundamentos : Conceitos Fundamentais : Era da Informação } \\
\text { Temas : Infraestrutura e Recursos do Setor de Telecomunicações : Infra-estrutura de } \\
\text { Telecomunicações : Compartilhamento de Infraestrutura } \\
\text { Temas : Políticas de Telecomunicações : Sigilo em Telecomunicações } \\
\text { Temas : Serviços no Setor de Telecomunicações : Internet }\end{array}$ \\
\hline
\end{tabular}

\section{Portaria Ministerial}

Portaria MCTIC no 353, de 19 de janeiro de 2018 - Estabelece o valor máximo da multa por infração às disposições da Lei 4.117/62 (Código Brasileiro de Telecomunicações)

\begin{tabular}{|l|l|}
\hline $\begin{array}{l}\text { Ó } \mathrm{r} \text { g ã o } \\
\text { Emissor }\end{array}$ & Ministério das Comunicações - Gabinete do Ministro. \\
\hline Nota Vigência & Data de publicação no DOU \\
\hline Dispositivos & CF, Art. 21, inciso XII, alínea a (em 15/08/1995); LGT, Art. 211, caput. \\
\hline Regulamenta & Lei n ${ }^{\circ}$ 4.117/1962 - Institui o Código Brasileiro de Telecomunicações. \\
\hline Publicação & Diário Oficial da União, Seção 1, 24-01-2018, pág. p. 1 \\
\hline Temas & $\begin{array}{l}\text { Temas : Administração do Setor de Telecomunicações : Fiscalização das Telecomunicações } \\
\text { Temas : Serviços no Setor de Telecomunicações : Radiodifusão }\end{array}$ \\
\hline
\end{tabular}

Portaria MCTIC n 699, de 6 de fevereiro de 2018 - Disciplina e aprova as regras para utilização de canais virtuais pelas entidades executantes dos serviços de radiodifusão de sons e imagens e de retransmissão de televisão do Sistema Brasileiro de Televisão Digital Terrestre - SBTVD- T.

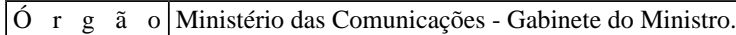

Emissor

\begin{tabular}{|l|l} 
Nota Vigência & Data de publicação no DOU \\
\hline
\end{tabular}

ARANHA, M.; LIMA, J.; QUELHO, R. Regulação do Setor de Telecomunicações em 2018. Revista de Direito, Estado e Telecomunicações, v. 11, n. 2, p. 177-230, outubro 2019.

DOI: https://doi.org/10.26512/lstr.v11i2.27083 


\begin{tabular}{|c|c|}
\hline Anexos & $\begin{array}{l}\text { Anexo - Anexo - Declaração sobre Utilização de Redes de Frequência Única (SFN - Single } \\
\text { Frequency Networks) para Designação de Canal Virtual (RTVD) }\end{array}$ \\
\hline Dispositivos & CF, Art. 21, inciso XII, alínea a (em 15/08/1995); LGT, Art. 211, caput. \\
\hline Alterada por & $\begin{array}{l}\text { Portaria MCTIC } n^{\circ} 1.908 \text {, de } 6 \text { de abril de } 2018 \text { - Altera a Portaria MCTIC } \text { n }^{\circ} 699 \text {, de } 06.02 .2018 \text {, } \\
\text { que disciplina e aprova as regras para utilização de canais virtuais pelas entidades executantes } \\
\text { dos serviços de radiodifusão de sons e imagens e de retransmissão de televisão do Sistema } \\
\text { Brasileiro de Televisão Digital Terrestre - SBTVD- T. }\end{array}$ \\
\hline \multirow[t]{3}{*}{ Revoga } & $\begin{array}{l}\text { Portaria MCTIC n }{ }^{\circ} 3.540 / 2017 \text { - Disciplina e aprova as regras para utilização de canais virtuais } \\
\text { pelas entidades executantes dos serviços de radiodifusão de sons e imagens e de retransmissão } \\
\text { de televisão do SBTVD-T, nos agrupamentos de municípios de Rio Verde-GO, Brasília-DF e } \\
\text { Goiânia-GO, e aprova a numeração dos canais virtuais. }\end{array}$ \\
\hline & $\begin{array}{l}\text { Portaria MCTIC n }{ }^{\circ} 3.992 / 2017 \text { - Fixa prazo de noventa dias para adaptação das prestadoras de } \\
\text { radiodifusão que cita para utilização de redes de frequência única (SFN). }\end{array}$ \\
\hline & $\begin{array}{l}\text { Portaria MCTIC n }{ }^{\circ} 6.053 / 2017 \text { - Altera o art. } 1^{\circ} \text { da Portaria MCTIC n }{ }^{\circ} 3.992 \text {, de } 14 \text { de julho de } \\
2017\end{array}$ \\
\hline Correlata & $\begin{array}{l}\text { Portaria } \mathrm{MC} \mathrm{n}^{\circ} 925 \text {, de } 22 \text { de agosto de } 2014 \text { - Regulamenta os Requisitos Técnicos dos Serviços } \\
\text { abrangidos pelo Sistema Brasileiro de TV Digital Terrestre. }\end{array}$ \\
\hline \multirow[t]{2}{*}{ Regulamenta } & Lei $\mathrm{n}^{\circ} 13.502$, de $1^{\circ}$ de novembro de 2017 \\
\hline & $\begin{array}{l}\text { Decreto }{ }^{\circ} \text { 5.820/2006 - Dispõe sobre a implantação do SBTVD-T, estabelece diretrizes para a } \\
\text { transição do sistema de transmissão analógica para o sistema de transmissão digital do serviço } \\
\text { de radiodifusão de sons e imagens e do serviço de retransmissão de televisão, e dá outras } \\
\text { providências. }\end{array}$ \\
\hline Publicação & Diário Oficial da União, Seção 1, 08-06-2018, pág. p. 123 \\
\hline Temas & Temas : Serviços no Setor de Telecomunicações : Radiodifusão \\
\hline
\end{tabular}

\begin{tabular}{|c|c|}
\hline $\begin{array}{l}\text { Portaria MC' } \\
\text { o serviço de ra }\end{array}$ & $\begin{array}{l}\text { TIC no 720, de } 7 \text { de fevereiro de } 2018 \text { - Aprova o Plano Nacional de Outorgas 2018/2019 para } \\
\text { diodifusão comunitária. }\end{array}$ \\
\hline $\begin{array}{lllll}O & \mathrm{r} & \mathrm{g} & \tilde{a} & \mathrm{o} \\
\text { Emissor } & \end{array}$ & Ministério das Comunicações - Gabinete do Ministro. \\
\hline Nota Vigência & Data de publicação no DOU \\
\hline Dispositivos & $\begin{array}{l}\text { CF, Art. 21, inciso XII, alínea a (em 15/08/1995); CF, Art. 220, } \$ 3^{\circ} \text {, inciso II; LGT, Art. 211, } \\
\text { caput. }\end{array}$ \\
\hline Revoga & $\begin{array}{l}\text { Portaria } \mathrm{MC} \mathrm{n}^{\circ} 1.775 \text {, de } 3 \text { de maio de } 2016 \\
\text { Portaria } \mathrm{MC} \mathrm{n}^{\circ} 1.776 \text {, de } 3 \text { de maio de } 2016\end{array}$ \\
\hline Regulamenta & $\begin{array}{l}\text { Lei } 13424 / 2017 \text { - Altera as Leis nos } 5.785 \text {, de } 23 \text { de junho de } 1972,9.612 \text {, de } 19 \text { de fevereiro } \\
\text { de } 1998,4.117 \text {, de } 27 \text { de agosto de } 1962,6.615 \text {, de } 16 \text { de dezembro de } 1978 \text {, para dispor sobre } \\
\text { o processo de renovação do prazo das concessões e permissões dos serviços de radiodifusão, e } \\
\text { dá outras providências. }\end{array}$ \\
\hline Publicação & Diário Oficial da União, Seção 1, 08-02-2018, pág. p. 24 \\
\hline
\end{tabular}

Portaria MCTIC n 1.909, de 5 de abril de 2018 - Altera a Portaria nº 4.334/2015/SEI-MC, que dispõe sobre o serviço de radiodifusão comunitária.

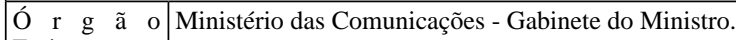

Emisso

\begin{tabular}{|c|c|}
\hline Nota Vigência & Data de publicação no DOU \\
\hline Dispositivos & CF, Art. 21, inciso XII, alínea a (em 15/08/1995); LGT, Art. 211, caput. \\
\hline Regulamenta & $\begin{array}{l}\text { Lei n }{ }^{\circ} 9.612 / 1998 \text { - Institui o Serviço de Radiodifusão Comunitária e dá outras providências. } \\
\text { Decreto } \text { n }^{\circ} 2.615 / 1998 \text { - Aprova o Regulamento do Serviço de Radiodifusão Comunitária. } \\
\text { Portaria MC nº 4.334, de } 17 \text { de setembro de } 2015 \text { - Dispõe sobre o serviço de radiodifusão } \\
\text { comunitária }\end{array}$ \\
\hline
\end{tabular}

ARANHA, M.; LIMA, J.; QUELHO, R. Regulação do Setor de Telecomunicações em 2018. Revista de Direito, Estado e Telecomunicações, v. 11, n. 2, p. 177-230, outubro 2019.

DOI: https://doi.org/10.26512/lstr.v11i2.27083 


\begin{tabular}{|l|l|}
\hline Publicação & Diário Oficial da União, Seção 1,09-04-2018, pág. p. 23 \\
\hline Temas & Temas : Serviços no Setor de Telecomunicações : Radiodifusão \\
\hline
\end{tabular}

Portaria MCTIC $\mathbf{n}^{\mathbf{0}} \mathbf{1 . 9 0 8}$, de 6 de abril de 2018 - Altera a Portaria MCTIC ${ }^{\circ}$ 699, de 06.02.2018, que disciplina e aprova as regras para utilização de canais virtuais pelas entidades executantes dos serviços de radiodifusão de sons e imagens e de retransmissão de televisão do Sistema Brasileiro de Televisão Digital Terrestre - SBTVD- T.

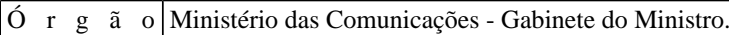

Emissor

\begin{tabular}{|l|l} 
Nota Vigência & Data de publicação no DOU.
\end{tabular}

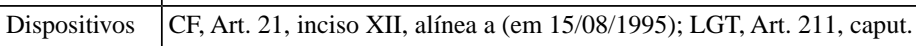

Altera $\quad$ Portaria MCTIC n ${ }^{\circ}$ 699, de 6 de fevereiro de 2018 - Disciplina e aprova as regras para utilização de canais virtuais pelas entidades executantes dos serviços de radiodifusão de sons e imagens e de retransmissão de televisão do Sistema Brasileiro de Televisão Digital Terrestre - SBTVDT.

Regulamenta Lei $^{\circ} 13.502$, de $1^{\circ}$ de novembro de 2017

Decreto $\mathrm{n}^{\circ}$ 5.820/2006 - Dispõe sobre a implantação do SBTVD-T, estabelece diretrizes para a transição do sistema de transmissão analógica para o sistema de transmissão digital do serviço de radiodifusão de sons e imagens e do serviço de retransmissão de televisão, e dá outras providências.

\begin{tabular}{|l|l|}
\hline Publicação & Diário Oficial da União, Seção 1,09-04-2018, pág. p. 23 \\
\hline Temas & Temas : Serviços no Setor de Telecomunicações : Radiodifusão \\
\hline
\end{tabular}

Portaria MCTIC n⿳0 1.976, de 12 de abril de 2018 - Altera a Portaria nº 4.334/2015/SEI-MC, que dispõe sobre o serviço de radiodifusão comunitária

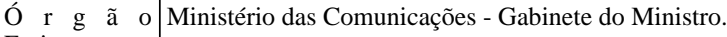

Emissor

Nota Vigência Data de publicação no DOU

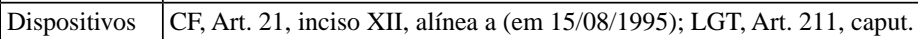

Regulamenta Lei n $^{\circ}$ 9.612/1998 - Institui o Serviço de Radiodifusão Comunitária e dá outras providências.

Decreto n 2.615/1998 - Aprova o Regulamento do Serviço de Radiodifusão Comunitária.

Portaria MC n 4.334, de 17 de setembro de 2015 - Dispõe sobre o serviço de radiodifusão comunitária

\begin{tabular}{|l|l|}
\hline Publicação & Diário Oficial da União, Seção 1, 13-04-2018, pág. p. 40 \\
\hline Temas & Temas : Serviços no Setor de Telecomunicações : Radiodifusão \\
\hline
\end{tabular}

Portaria MCTIC n 2.105, de 16 de abril de 2018 - Estabelece a exibição de cartela informativa pelas entidades que executam o serviço de Radiodifusão de Sons e Imagens e o serviço de Retransmissão de Televisão, em tecnologia digital, que alterarem seu canal físico, orientando a população quanto aos procedimentos de sintonia do novo canal.

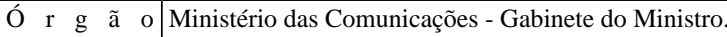

Emissor

\begin{tabular}{l|l} 
Nota Vigência & Data de publicação no DOU
\end{tabular}

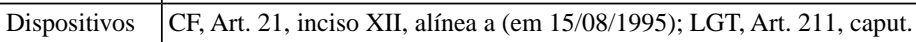

Regulamenta Lei n $^{\circ}$ 4.117/1962 - Institui o Código Brasileiro de Telecomunicações.

Lei $n^{\circ} 13.502$, de $1^{\circ}$ de novembro de 2017

\begin{tabular}{l|l}
\hline Publicação & Diário Oficial da União, Seção 1, 17-04-2018, pág. p. 9
\end{tabular}

ARANHA, M.; LIMA, J.; QUELHO, R. Regulação do Setor de Telecomunicações em 2018. Revista de Direito, Estado e Telecomunicações, v. 11, n. 2, p. 177-230, outubro 2019.

DOI: https://doi.org/10.26512/lstr.v11i2.27083 
\begin{tabular}{|l|l}
\hline Temas & Temas : Serviços no Setor de Telecomunicações : Radiodifusão
\end{tabular}

\begin{tabular}{|c|c|}
\hline \multicolumn{2}{|c|}{$\begin{array}{l}\text { Portaria MCTIC no 3.045, de } 7 \text { de junho de } 2018 \text { - Dispõe sobre a destinação do saldo de recursos remanescente, } \\
\text { proveniente da licitação de que trata o Edital n 2/2014-SOR/SPR/CD-ANATEL, administrados pela Associação } \\
\text { Administradora do Processo de Redistribuição e Digitalização de Canais de TV e RTV - EAD. }\end{array}$} \\
\hline 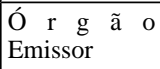 & Ministério das Comunicações - Gabinete do Ministro. \\
\hline Nota Vigência & Data de publicação no DOU \\
\hline Dispositivos & CF, Art. 21, inciso XII, alínea a (em 15/08/1995); LGT, Art. 211, caput. \\
\hline Regulamenta & $\begin{array}{l}\text { Lei no 4.117/1962 - Institui o Código Brasileiro de Telecomunicações. } \\
\text { Lei n }{ }^{\circ} \text { 9.472/1997 - Dispõe sobre a organização dos serviços de telecomunicações, a criação e } \\
\text { funcionamento de um órgão regulador e outros aspectos institucionais, nos termos da Emenda } \\
\text { Constitucional no } 8 \text {, de } 1995 \text {. } \\
\text { Decreto no 52.795/1963 - Aprova o Regulamento dos Serviços de Radiodifusão. } \\
\text { Decreto no 5.820/2006 - Dispõe sobre a implantação do SBTVD-T, estabelece diretrizes para a } \\
\text { transição do sistema de transmissão analógica para o sistema de transmissão digital do serviço } \\
\text { de radiodifusão de sons e imagens e do serviço de retransmissão de televisão, e dá outras } \\
\text { providências. }\end{array}$ \\
\hline Publicação & Diário Oficial da União, Seção 1, 08-06-2018, pág. p. 123 \\
\hline Temas & $\begin{array}{l}\text { Temas : Serviços no Setor de Telecomunicações : Radiodifusão } \\
\text { Temas : Serviços no Setor de Telecomunicações : Serviço Móvel Pessoal (SMP) }\end{array}$ \\
\hline
\end{tabular}

Portaria MCTIC n⿳ 3.238, de 20 de junho de 2018 - Dispõe sobre permissão e concessão para execução dos serviços de radiodifusão sonora em frequência modulada e de sons e imagens, com fins exclusivamente educativos.

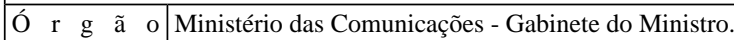
Emissor \begin{tabular}{l|l} 
Nota Vigência & Data de publicação no DOU
\end{tabular}

\begin{tabular}{l|l}
\hline Anexos & Anexo 1 - Anexo I - Requerimento de Outorga para Pessoas Jurídicas de Direito Público
\end{tabular}

Anexo 10 - Anexo X - Requerimento de Transferência de Outorga para quando a Cedente for Instituição de Educação Superior de Natureza Privada e a Cessionária for Pessoa Jurídica de Direito Público ou outra Instituição de Educação Superior de Natureza Privada

Anexo 11 - Anexo XI - Requerimento de Transferência de Outorga para quando a Cedente for Fundação de Direito Privado e a Cessionária for Pessoa Jurídica de Direito Público, Instituição de Educação Superior de Natureza Privada ou outra Fundação de Direito Privado

Anexo 2 - Anexo II - Requerimento de Outorga para Instituições de Educação Superior de Natureza Privada

Anexo 3 - Anexo III - Requerimento de Outorga para as Fundações de Direito Privado

Anexo 4 - Anexo IV - Requerimento de Renovação de Outorga para as Pessoas Jurídicas de Direito Público

Anexo 5 - Anexo V - Requerimento de Renovação de Outorga para as Instituições de Educação Superior de Natureza Privada

Anexo 6 - Anexo VI - Requerimento de Renovação de Outorga para as Fundações de Direito Privado

Anexo 7 - Anexo VII - Comunicação de Alteração de Quadro Diretivo/Societário

Anexo 8 - Anexo VIII - Comunicação de Alteração Estatutária e Contratual

Anexo 9 - Anexo IX - Requerimento de Transferência de Outorga para as Pessoas Jurídicas de Direito Público

Dispositivos CF, Art. 21, inciso XII, alínea a (em 15/08/1995); CF, Art. 221, inciso I; CF, Art. 223, caput; LGT, Art. 211, caput.

\begin{tabular}{|l|l|}
\hline Revoga & Portaria $\mathrm{MC} \mathrm{n}^{\circ}$ 4.335, de 17 de setembro de 2015 - Dispõe sobre os procedimentos de permissão
\end{tabular} e concessão para execução dos serviços de radiodifusão sonora em frequência modulada e de sons e imagens, com finalidade exclusivamente educativa

ARANHA, M.; LIMA, J.; QUELHO, R. Regulação do Setor de Telecomunicações em 2018. Revista de Direito, Estado e Telecomunicações, v. 11, n. 2, p. 177-230, outubro 2019.

DOI: https://doi.org/10.26512/lstr.v11i2.27083 


\begin{tabular}{|l|l|}
\hline Regulamenta & $\begin{array}{l}\text { Anexo ao Decreto } \mathrm{n}^{\circ} \text { 52.795, de } 31 \text { de outubro de } 1963 \text { - Regulamento dos Serviços de } \\
\text { Radiodifusão. } \\
\text { Portaria } M C \mathrm{n}^{\circ} 4.335, \text { de } 17 \text { de setembro de } 2015 \text { - Dispõe sobre os procedimentos de permissão } \\
\text { e concessão para execução dos serviços de radiodifusão sonora em frequência modulada e de } \\
\text { sons e imagens, com finalidade exclusivamente educativa }\end{array}$ \\
\hline Publicação & Diário Oficial da União, Seção 1, 21-06-2018, pág. p. 6 \\
\hline Temas & $\begin{array}{l}\text { Temas : Aplicações de Telecomunicações : Aplicações Educacionais } \\
\text { Temas : Serviços no Setor de Telecomunicações : Radiodifusão }\end{array}$ \\
\hline
\end{tabular}

\begin{tabular}{|c|c|}
\hline \multicolumn{2}{|c|}{$\begin{array}{l}\text { Portaria MCTIC n⿳ 6.197, de } 5 \text { de dezembro de } 2018 \text { - Dispõe sobre o Serviço de Retransmissão de Televisão, } \\
\text { ancilar ao Serviço de Radiodifusão de Sons e Imagens. }\end{array}$} \\
\hline 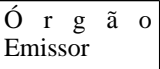 & Ministério da Ciência, Tecnologia, Inovações e Comunicações - Gabinete do Ministro. \\
\hline Nota Vigência & Data de publicação no DOU \\
\hline Anexos & $\begin{array}{l}\text { Anexo } 1 \text { - Anexo I - Requerimento de Autorização para Execução do Serviço de Retransmissão } \\
\text { de Televisão em Caráter Primário } \\
\text { Anexo } 2 \text { - Anexo II - Requerimento de Autorização para Execução do Serviço de Retransmissão } \\
\text { de Televisão em Caráter Secundário } \\
\text { Anexo } 3 \text { - Anexo III - Requerimento de Transferência da Autorização }\end{array}$ \\
\hline Dispositivos & CF, Art. 21, inciso XII, alínea a (em 15/08/1995); LGT, Art. 211, caput. \\
\hline Altera & $\begin{array}{l}\text { Portaria MC } \mathrm{n}^{\circ} 366 \text {, de } 14 \text { de agosto de } 2012 \text { - Dispõe sobre os procedimentos de autorização } \\
\text { para a execução dos serviços de retransmissão e repetição de televisão. } \\
\text { Portaria MC } \mathrm{n}^{\circ} 4.287 \text {, de } 21 \text { de setembro de } 2015 \text { - Dispõe sobre os procedimentos de seleção } \\
\text { pública e de autorização para a execução do Serviço de Retransmissão de Televisão, com } \\
\text { utilização de tecnologia digital, ancilar ao Serviço de Radiodifusão de Sons e Imagens, durante } \\
\text { a transição do sistema de transmissão analógica para o sistema de transmissão digital e dá outras } \\
\text { providências } \\
\text { Portaria } M C n^{\circ} 6.738 \text {, de } 21 \text { de dezembro de } 2015 \text { - Dispõe sobre os procedimentos de autorização } \\
\text { para a execução do Serviço de Retransmissão de Televisão, em caráter secundário, com utilização } \\
\text { de tecnologia digital e dá outras providências. }\end{array}$ \\
\hline Regulamenta & 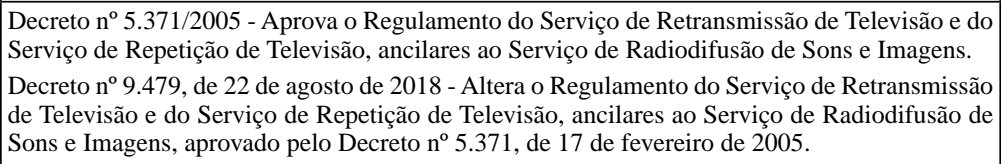 \\
\hline Publicação & Diário Oficial da União, Seção 1, 10-12-2018, pág. p. 65 \\
\hline Temas & $\begin{array}{l}\text { Temas : Serviços no Setor de Telecomunicações : Radiodifusão : Serviço de Retransmissão de } \\
\text { Televisão (RTV) }\end{array}$ \\
\hline
\end{tabular}

\section{Resolução}

Resolução da ANATEL n $^{\circ}$ 690, de 29 de janeiro de 2018 - Aprova o Regulamento de Restituição e Compensação das Receitas Administradas pela Anatel e dá outras providências.

\begin{tabular}{|l|l|}
\hline $\begin{array}{l}\text { Ó } \mathrm{r} \text { g ã o } \\
\text { Emissor }\end{array}$ & ANATEL - Conselho Diretor. \\
\hline Nota Vigência & Data de publicação no DOU. \\
\hline Anexos & $\begin{array}{l}\text { Anexo - Anexo - Regulamento de Restituição e Compensação das Receitas Administradas pela } \\
\text { Anatel }\end{array}$ \\
\hline Dispositivos & LGT, Art. 50, caput. \\
\hline
\end{tabular}

ARANHA, M.; LIMA, J.; QUELHO, R. Regulação do Setor de Telecomunicações em 2018. Revista de Direito, Estado e Telecomunicações, v. 11, n. 2, p. 177-230, outubro 2019.

DOI: https://doi.org/10.26512/1str.v11i2.27083 


\begin{tabular}{|c|c|}
\hline Altera & $\begin{array}{l}\text { Anexo à Resolução da ANATEL } n^{\circ} 247 \text {, de } 14 \text { de dezembro de } 2000 \text { - Regulamento de } \\
\text { Arrecadação da Contribuição das Prestadoras de Serviços de Telecomunicações para o Fundo } \\
\text { de Universalização dos Serviços de Telecomunicações - FUST. } \\
\text { Anexo à Resolução da ANATEL n }{ }^{\circ} 255 \text {, de } 29 \text { de março de } 2001 \text { - Regulamento para Arrecadação } \\
\text { de Receitas do Fundo de Fiscalização das Telecomunicações - FISTEL. }\end{array}$ \\
\hline Regulamenta & 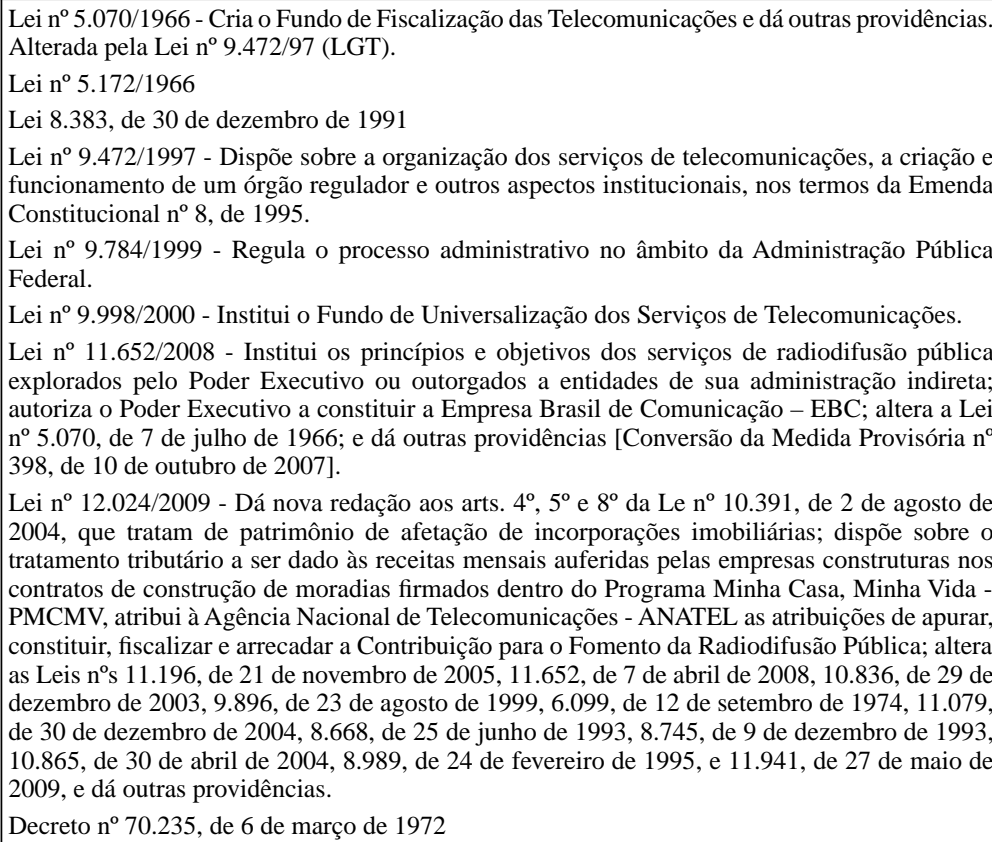 \\
\hline Publicação & Diário Oficial da União, Seção 1, 30-01-2018, págs. p. 5-6 \\
\hline Temas & $\begin{array}{l}\text { Temas : Administração do Setor de Telecomunicações : Tributação no Setor de Telecomunicações } \\
\text { Temas : Políticas de Telecomunicações : Fundos Setoriais de Telecomunicações }\end{array}$ \\
\hline
\end{tabular}

\begin{tabular}{|c|c|}
\hline \multicolumn{2}{|c|}{$\begin{array}{l}\text { Resolução da ANATEL n } \mathbf{n}^{\mathbf{6}} \mathbf{9 1} \text {, de } 22 \text { de fevereiro de } 2018 \text { - Cria Centro de Altos Estudos em Telecomunicações } \\
\text { - Ceatel e dá outras providências }\end{array}$} \\
\hline $\begin{array}{lllll}\text { Ó } & \mathrm{r} & \mathrm{g} & \tilde{\mathrm{a}} & \mathrm{o} \\
\text { Emissor } & & \end{array}$ & ANATEL - Conselho Diretor. \\
\hline Nota Vigência & Data de publicação no DOU. \\
\hline Dispositivos & LGT, Art. $2^{\circ}$, inciso IV; LGT, Art. 10, Parágrafo Único. \\
\hline Altera & $\begin{array}{l}\text { Anexo - Regimento Interno da Agência Nacional de Telecomunicações - ANATEL - Regimento } \\
\text { Interno da Agência Nacional de Telecomunicações - ANATEL. }\end{array}$ \\
\hline \multirow[t]{2}{*}{ Regulamenta } & $\begin{array}{l}\text { Lei n } n^{\circ} 9.472 / 1997 \text { - Dispõe sobre a organização dos serviços de telecomunicações, a criação e } \\
\text { funcionamento de um órgão regulador e outros aspectos institucionais, nos termos da Emenda } \\
\text { Constitucional } n^{\circ} 8, \text { de } 1995 \text {. }\end{array}$ \\
\hline & $\begin{array}{l}\text { Decreto no } 5.707 / 2006 \text { - Institui a Política e as Diretrizes para o Desenvolvimento de Pessoal } \\
\text { da administração pública federal direta, autárquica e fundacional, e regulamenta dispositivos da } \\
\text { Lei } \mathrm{n}^{\circ} 8.112 \text {, de } 11 \text { de dezembro de } 1990 \text {. }\end{array}$ \\
\hline Publicação & Diário Oficial da União, Seção 1, 23-02-2018, págs. p. 44-45 \\
\hline Temas & $\begin{array}{l}\text { Temas : Atores no Setor de Telecomunicações : ANATEL } \\
\text { Temas : Políticas de Telecomunicações : Pesquisa \& Desenvolvimento }\end{array}$ \\
\hline
\end{tabular}

ARANHA, M.; LIMA, J.; QUELHO, R. Regulação do Setor de Telecomunicações em 2018. Revista de Direito, Estado e Telecomunicações, v. 11, n. 2, p. 177-230, outubro 2019.

DOI: https://doi.org/10.26512/lstr.v11i2.27083 
Temas : Ramos Jurídicos Afins : Direito Administrativo

Resolução da ANATEL no 692, de 12 de abril de 2018 - Altera o Regulamento do Serviço de Acesso Condicionado (SeAC), aprovado pela Resolução $n^{\circ} 581$, de 26 de março de 2012, e alterado pela Resolução $n^{\circ}$ 618 , de 24 de julho de 2013.

\begin{tabular}{|l|l|}
\hline $\begin{array}{l}\text { Ó } \mathrm{r} \text { ã o } \\
\text { Emissor }\end{array}$ & ANATEL - Conselho Diretor. \\
\hline Nota Vigência & 90 dias após publicação no DOU, \\
\hline Dispositivos & LGT, Art. 69, caput. \\
\hline Altera & $\begin{array}{l}\text { Regulamento do Serviço de Acesso Condicionado (SeAC) - Regulamento do Serviço de Acesso } \\
\text { Condicionado (SeAC). } \\
\text { Anexo I - Regulamento Geral de Acessibilidade em Telecomunicações - Anexo I - Regulamento } \\
\text { Geral de Acessibilidade em Telecomunicações }\end{array}$ \\
\hline Regulamenta & $\begin{array}{l}\text { Lei no 12.485/2011 - Dispõe sobre a comunicação audiovisual de acesso condicionado; altera a } \\
\text { Medida Provisória no 2.228-1, de 6 de setembro de 2001, e as Leis n's 11.437, de 28 de dezembro } \\
\text { de 2006, 5.070, de 7 de julho de 1966, 8.977, de 6 de janeiro de 1995, e 9.472, de 16 de julho } \\
\text { de 1997; e dá outras providências. }\end{array}$ \\
\hline Publicação & Diário Oficial da União, Seção 1, 16-04-2018, págs. p. 4-5 \\
\hline Temas & Temas : Serviços no Setor de Telecomunicações : Serviço de Acesso Condicionado (SeAC) \\
\hline
\end{tabular}

\begin{tabular}{|l|l|}
\hline $\begin{array}{l}\text { Resolução da ANATEL no 693, de } 17 \text { de julho de 2018 - Aprova o Regulamento Geral de Interconexão - RGI } \\
\text { e altera o Regulamento dos Serviços de Telecomunicações, o Regimento Interno da Anatel e os Regulamentos } \\
\text { de Remuneração pelo uso de redes do Serviço Telefônico Fixo Comutado e do Serviço Móvel Pessoal. }\end{array}$ \\
\hline $\begin{array}{l}\text { Ó r g ã o } \\
\text { Emissor }\end{array}$ & ANATEL - Conselho Diretor. \\
\hline Nota Vigência & Data de publicação no DOU. \\
\hline Dispositivos & LGT, Art. 19, inciso XIX; LGT, Art. 155, caput. \\
\hline Altera & $\begin{array}{l}\text { Anexo à Resolução da ANATEL n } 73, \text { de 25 de novembro de 1998 - Regulamento dos Serviços } \\
\text { de Telecomunicações. } \\
\text { Anexo à Resolução da ANATEL no 438, de 10 de julho de 2006 - Regulamento de Remuneração } \\
\text { pelo Uso de Redes de Prestadoras do Serviço Móvel Pessoal - SMP. } \\
\text { Regulamento de Remuneração pelo Uso de Redes de Prestadoras do Serviço Telefônico Fixo } \\
\text { Comutado - STFC - Regulamento de Remuneração pelo Uso de Redes de Prestadoras do Serviço } \\
\text { Telefônico Fixo Comutado - STFC. } \\
\text { Anexo - Regimento Interno da Agência Nacional de Telecomunicações - ANATEL - Regimento } \\
\text { Interno da Agência Nacional de Telecomunicações - ANATEL. }\end{array}$ \\
\hline Revoga & $\begin{array}{l}\text { Resolução da ANATEL no 410/2005 - Aprova o Regulamento Geral de Interconexão. - Anexo } \\
\text { - Regulamento Geral de Interconexão. }\end{array}$ \\
\hline Regulamenta & $\begin{array}{l}\text { Lei no 9.472/1997 - Dispõe sobre a organização dos serviços de telecomunicações, a criação e } \\
\text { funcionamento de um órgão regulador e outros aspectos institucionais, nos termos da Emenda } \\
\text { Constitucional no 8, de 1995. }\end{array}$ \\
\hline Publicação & $\begin{array}{l}\text { Diário Oficial da União, Seção 1, 18-07-2018, págs. p. 10-12 } \\
\text { Diário Oficial da União, Seção 1, 05-11-2018, pág. p. 11 [ Retificação ] }\end{array}$ \\
\hline $\begin{array}{l}\text { Temas : Infra-estrutura e Recursos do Setor de Telecomunicações : Redes de Telecomunicações } \\
\text { Interconexão }\end{array}$ \\
\hline
\end{tabular}

Resolução da ANATEL n $^{0}$ 694, de 17 de julho de 2018 - Altera o Plano Geral de Metas de Competição PGMC, aprovado pela Resolução ${ }^{\circ}$ 600, de 8 de novembro de 2012; o Regulamento de Remuneração pelo Uso de Redes de Prestadoras do Serviço Telefônico Fixo Comutado - STFC, aprovado pela Resolução ${ }^{\circ}$ 588, de 7 de maio de 2012; o Regulamento de Remuneração pelo Uso de Redes de Prestadoras do Serviço Móvel Pessoal - SMP, aprovado pela Resolução n 438, de 10 de julho de 2006; a Resolução nº 396, de 31 de março de 2005;

ARANHA, M.; LIMA, J.; QUELHO, R. Regulação do Setor de Telecomunicações em 2018. Revista de Direito, Estado e Telecomunicações, v. 11, n. 2, p. 177-230, outubro 2019.

DOI: https://doi.org/10.26512/1str.v11i2.27083 
o Regulamento de Aplicação de Sanções Administrativas, aprovado pela Resolução $n^{\circ}$ 589, de 7 de maio de 2012; revoga a Resolução ${ }^{\circ} 437$, de 8 de junho de 2006; e dá outras providências.

\begin{tabular}{|c|c|}
\hline $\begin{array}{lllll}\text { Ó } & \mathrm{r} & \mathrm{g} & \tilde{a} & \mathrm{o} \\
\text { Emissor } & \end{array}$ & ANATEL - Conselho Diretor. \\
\hline Nota Vigência & Data de publicação no DOU. \\
\hline Anexos & $\begin{array}{l}\text { Anexo } 1 \text { - Anexo I - Diretrizes Metodológicas para Identificação de Mercado Relevante de } \\
\text { Atacado e dos Grupos com PMS } \\
\text { Anexo } 2 \text { - Anexo II - Mercados Relevantes e Medidas Regulatórias Assimétricas } \\
\text { Anexo } 3 \text { - Anexo III - Homologação de Ofertas de Referência de Produtos de Atacado } \\
\text { Anexo } 4 \text { - Anexo IV - Categorização dos Municípios }\end{array}$ \\
\hline Dispositivos & LGT, Art. $2^{\circ}$, inciso III; LGT, Art. 155 , caput. \\
\hline Altera & $\begin{array}{l}\text { Resolução da ANATEL no 396/2005 - Aprova o Regulamento de Separação e Alocação de } \\
\text { Contas. } \\
\text { Anexo à Resolução da ANATEL n }{ }^{\circ} 438 \text {, de } 10 \text { de julho de } 2006 \text { - Regulamento de Remuneração } \\
\text { pelo Uso de Redes de Prestadoras do Serviço Móvel Pessoal - SMP. } \\
\text { Regulamento de Remuneração pelo Uso de Redes de Prestadoras do Serviço Telefônico Fixo } \\
\text { Comutado - STFC - Regulamento de Remuneração pelo Uso de Redes de Prestadoras do Serviço } \\
\text { Telefônico Fixo Comutado - STFC. } \\
\text { Regulamento de Aplicação de Sanções Administrativas - Regulamento de Aplicação de Sanções } \\
\text { Administrativas. } \\
\text { Anexo - Plano Geral de Metas de Competição (PGMC) - Plano Geral de Metas de Competição } \\
\text { (PGMC). }\end{array}$ \\
\hline Revoga & $\begin{array}{l}\text { Resolução da ANATEL n }{ }^{\circ} \text { 437/2006 - Determina os Grupos detentores de Poder de Mercado } \\
\text { Significativo (PMS) na oferta de Exploração Industrial de Linha Dedicada (EILD). }\end{array}$ \\
\hline Regulamenta & 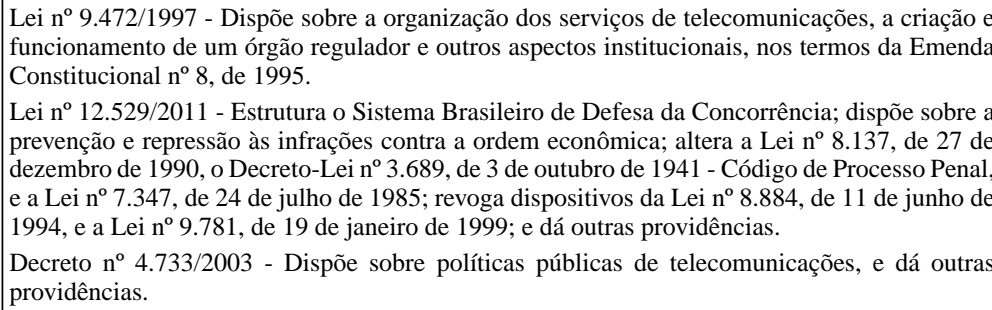 \\
\hline Publicação & Diário Oficial da União, Seção 1, 23-07-2018, págs. p. 3-40 \\
\hline Temas & $\begin{array}{l}\text { Temas : Políticas de Telecomunicações : Concorrência no Setor de Telecomunicações } \\
\text { Temas : Serviços no Setor de Telecomunicações : Serviço Móvel Pessoal (SMP) } \\
\text { Temas : Serviços no Setor de Telecomunicações : Serviço de Acesso Condicionado (SeAC) } \\
\text { Temas : Serviços no Setor de Telecomunicações : Serviço de Comunicação Multimídia (SCM) }\end{array}$ \\
\hline
\end{tabular}

Resolução da ANATEL n 695, de 20 de julho de 2018 - Aprova o Regulamento de Cobrança de Preço Público pelo Direito de Uso de Radiofrequências.

\begin{tabular}{|l|l|}
\hline $\begin{array}{l}\text { Ó } \mathrm{r} g \text { ã o } \\
\text { Emissor }\end{array}$ & ANATEL - Conselho Diretor. \\
\hline Nota Vigência & 180 dias após a publicação no DOU. \\
\hline Anexos & $\begin{array}{l}\text { Anexo - Anexo - Regulamento de Cobrança de Preço Público pelo Direito de Uso de } \\
\text { Radiofrequências }\end{array}$ \\
\hline Dispositivos & LGT, Art. 48, $\S 1^{\circ}$, inciso II; LGT, Art. 48, § $1^{\circ}$, inciso III; LGT, Art. 48, § $1^{\circ}$, inciso IV. \\
\hline Altera & $\begin{array}{l}\text { Anexo à Resolução da ANATEL no } 65, \text { de } 29 \text { de outubro de } 1998 \text { - Regulamento de Licitação } \\
\text { para Concessão, Permissão e Autorização de Serviço de Telecomunicações e de Uso de } \\
\text { Radiofreqüência. }\end{array}$
\end{tabular}

ARANHA, M.; LIMA, J.; QUELHO, R. Regulação do Setor de Telecomunicações em 2018. Revista de Direito, Estado e Telecomunicações, v. 11, n. 2, p. 177-230, outubro 2019.

DOI: https://doi.org/10.26512/lstr.v11i2.27083 


\begin{tabular}{|l|l|}
\hline & $\begin{array}{l}\text { Anexo à Resolução da ANATEL no 255, de 29 de março de 2001 - Regulamento para Arrecadação } \\
\text { de Receitas do Fundo de Fiscalização das Telecomunicações - FISTEL. } \\
\text { Resolução da ANATEL no 387/2004 - Aprova a Alteração do Regulamento de Cobrança de } \\
\text { Preço Público pelo Direito de Uso de Radiofrequêencias. } \\
\text { Resolução da ANATEL n }{ }^{\circ} \text { 635, de } 9 \text { de maio de } 2014 \text { - Aprova o Regulamento sobre Autorização } \\
\text { de Uso Temporário de Radiofrequências. }\end{array}$ \\
\hline Regulamenta & $\begin{array}{l}\text { Lei no 9.472/1997 - Dispõe sobre a organização dos serviços de telecomunicações, a criação e } \\
\text { funcionamento de um órgão regulador e outros aspectos institucionais, nos termos da Emenda } \\
\text { Constitucional no 8, de 1995. } \\
\text { Decreto no 2.338/1997 - Aprova o Regulamento da Agência Nacional de Telecomunicações, e } \\
\text { dá outras providências. }\end{array}$ \\
\hline Publicação & Diário Oficial da União, Seção 1, 23-07-2018, págs. p. 40-41 \\
\hline Temas & Temas : Administração do Setor de Telecomunicações : Outorgas : Preço Público e Preço Privado \\
\hline
\end{tabular}

\begin{tabular}{|c|c|}
\hline $\begin{array}{l}\text { Resolução da } \\
\text { que autoriza } v \\
\text { serviços de ter }\end{array}$ & $\begin{array}{l}\text { ANATEL n } \mathbf{0} \text { 696, de } 23 \text { de julho de } \mathbf{2 0 1 8} \text { - Revoga a Resolução no } 530 \text {, de } 10 \text { de junho de } 2009 \text {, } \\
\text { alores para aquisição ou alienação de bens móveis e imóveis e para a contratação de obras e } \\
\text { ceiros. }\end{array}$ \\
\hline $\begin{array}{l}\text { Ó } \quad r \quad g \quad \tilde{a} \quad o \\
\text { Emissor }\end{array}$ & ANATEL - Conselho Diretor. \\
\hline Nota Vigência & Data de publicação no DOU. \\
\hline Dispositivos & LGT, Art. 22, inciso XI; LGT, Art. 22, inciso XII. \\
\hline Revoga & $\begin{array}{l}\text { Resolução da ANATEL no 530/2009 - Autoriza valores para aquisição ou alienação de bens } \\
\text { móveis e imóveis ou para a contratação de obras e serviços de terceiros. }\end{array}$ \\
\hline Regulamenta & $\begin{array}{l}\text { Lei } n^{\circ} 9.472 / 1997 \text { - Dispõe sobre a organização dos serviços de telecomunicações, a criação e } \\
\text { funcionamento de um órgão regulador e outros aspectos institucionais, nos termos da Emenda } \\
\text { Constitucional } n^{\circ} 8 \text {, de } 1995 \text {. }\end{array}$ \\
\hline Publicação & Diário Oficial da União, Seção 1, 24-07-2018, pág. p. 160 \\
\hline Temas & Temas : Atores no Setor de Telecomunicações : ANATEL \\
\hline
\end{tabular}

Resolução da ANATEL $\mathbf{n}^{\circ}$ 697, de 28 de agosto de 2018 - Atribui e destina faixas de radiofrequência ao Serviço de Radioamador e aprova o Regulamento sobre Condições de Uso de Radiofrequências pelo Serviço de Radioamador.

\begin{tabular}{|c|c|}
\hline $\begin{array}{lllll}\text { Ó } & \mathrm{r} & \mathrm{g} & \tilde{\mathrm{a}} & \mathrm{o} \\
\text { Emissor } & & \end{array}$ & ANATEL - Conselho Diretor. \\
\hline Nota Vigência & 90 dias após a data de publicação no DOU \\
\hline Anexos & $\begin{array}{l}\text { Anexo - Anexo - Regulamento sobre Condições de Uso de Radiofrequências pelo Serviço de } \\
\text { Radioamador }\end{array}$ \\
\hline Dispositivos & LGT, Art. 19, inciso VIII. \\
\hline Revoga & $\begin{array}{l}\text { Resolução da ANATEL no 452/2006 - Aprova o Regulamento sobre Condições de Uso de } \\
\text { Radiofreqüências pelo Serviço de Radioamador. - Anexo - Regulamento sobre Condições de } \\
\text { Uso de Radiofrequiências pelo Serviço de Radioamador. }\end{array}$ \\
\hline Regulamenta & $\begin{array}{l}\text { Lei }{ }^{\circ} 9.472 / 1997 \text { - Dispõe sobre a organização dos serviços de telecomunicações, a criação e } \\
\text { funcionamento de um órgão regulador e outros aspectos institucionais, nos termos da Emenda } \\
\text { Constitucional } n^{\circ} 8 \text {, de } 1995 \text {. }\end{array}$ \\
\hline Publicação & Diário Oficial da União, Seção 1, 30-08-2018, págs. p. 20-21 \\
\hline Temas & $\begin{array}{l}\text { Temas : Infra-estrutura e Recursos do Setor de Telecomunicações : Espectro de Radiofrequência } \\
\text { : Atribuição, Destinação e Distribuição de Radiofrequência } \\
\text { Temas : Infraestrutura e Recursos do Setor de Telecomunicações : Espectro de Radiofrequência } \\
\text { : Condições de Uso de Radiofrequência e Canalização (Distribuição de Canais) }\end{array}$ \\
\hline
\end{tabular}

ARANHA, M.; LIMA, J.; QUELHO, R. Regulação do Setor de Telecomunicações em 2018. Revista de Direito, Estado e Telecomunicações, v. 11, n. 2, p. 177-230, outubro 2019.

DOI: https://doi.org/10.26512/1str.v11i2.27083 
Temas : Serviços no Setor de Telecomunicações : Radioamador

\begin{tabular}{|l|l|}
\hline $\begin{array}{l}\text { Resolução da ANATEL } \mathbf{n}^{\mathbf{0}} \mathbf{6 9 8} \text {, de } 27 \text { de setembro de } 2018 \text { - Institui o Comitê de Prestadoras de Pequeno } \\
\text { Porte de Serviços de Telecomunicações junto à Anatel e aprova seu Regimento Interno. }\end{array}$ \\
\hline $\begin{array}{l}\text { Ó r g ã o } \\
\text { Emissor }\end{array}$ & ANATEL - Conselho Diretor. \\
\hline Nota Vigência & Data de publicação no DOU \\
\hline Anexos & $\begin{array}{l}\text { Anexo - Anexo - Regimento Interno do Comitê de Prestadoras de Pequeno Porte de Serviços } \\
\text { de Telecomunicações junto à ANATEL }\end{array}$ \\
\hline Dispositivos & LGT, Art. 2 ${ }^{\circ}$, inciso III; LGT, Art. 6º , caput; LGT, Art. 127, inciso II. \\
\hline Regulamenta & $\begin{array}{l}\text { Lei no 9.472/1997 - Dispõe sobre a organização dos serviços de telecomunicações, a criação e } \\
\text { funcionamento de um órgão regulador e outros aspectos institucionais, nos termos da Emenda } \\
\text { Constitucional no 8, de 1995. }\end{array}$ \\
\hline Publicação & Diário Oficial da União, Seção 1, 28-09-2018, págs. p. 22-23 \\
\hline Temas & $\begin{array}{l}\text { Temas : Atores no Setor de Telecomunicações : ANATEL } \\
\text { Temas : Atores no Setor de Telecomunicações : Prestadora / Operadora }\end{array}$ \\
\hline
\end{tabular}

Resolução da ANATEL n $^{\circ}$ 699, de 28 de setembro de 2018 - Altera o Anexo II ao Regulamento sobre Áreas Locais para o Serviço Telefônico Fixo Comutado Destinado ao Uso do Público em Geral - STFC.

\begin{tabular}{|l|l|}
\hline $\begin{array}{l}\text { Ó } \mathrm{r} \text { g a } \\
\text { Emissor }\end{array}$ & ANATEL - Conselho Diretor. \\
\hline Nota Vigência & 120 dias após a publicação no DOU \\
\hline Anexos & $\begin{array}{l}\text { Anexo - Anexo - Alterações ao Anexo II do Regulamento sobre Áreas Locais para o Serviço } \\
\text { Telefônico Fixo Comutado Destinado ao Uso do Público em Geral - STFC }\end{array}$ \\
\hline Dispositivos & LGT, Art. 64, Parágrafo Único. \\
\hline Altera & $\begin{array}{l}\text { Anexo à Resolução da ANATEL no 560, de 21 de janeiro de 2011 - Regulamento sobre Áreas } \\
\text { Locais para o Serviço Telefônico Fixo Comutado Destinado ao Uso do Público em Geral - } \\
\text { STFC. }\end{array}$ \\
\hline Regulamenta & $\begin{array}{l}\text { Lei no 9.472/1997 - Dispõe sobre a organização dos serviços de telecomunicações, a criação e } \\
\text { funcionamento de um órgão regulador e outros aspectos institucionais, nos termos da Emenda } \\
\text { Constitucional no 8, de 1995. }\end{array}$ \\
\hline Publicação & Diário Oficial da União, Seção 1, 02-10-2018, pág. p. 16 \\
\hline Temas & Temas : Serviços no Setor de Telecomunicações : Serviço Telefônico Fixo Comutado (STFC) \\
\hline
\end{tabular}

Resolução da ANATEL no 700, de 28 de setembro de 2018 - Aprova o Regulamento sobre a Avaliação da Exposição Humana a Campos Elétricos, Magnéticos e Eletromagnéticos Associados à Operação de Estações Transmissoras de Radiocomunicação.

\begin{tabular}{lllll|l}
\hline Ó & $\mathrm{r}$ & $\mathrm{g}$ & $\tilde{a}$ & $\mathrm{o}$ & ANATEL - Conselho Diretor.
\end{tabular}

Emisso

\begin{tabular}{|l|l|}
\hline Nota Vigência & 120 dias da publicação no DOU \\
\hline Anexos & $\begin{array}{l}\text { Anexo - Anexo - Regulamento sobre a Avaliação da Exposição Humana a Campos Elétricos, } \\
\text { Magnéticos e Eletromagnéticos Associados à Operação de Estações Transmissoras de } \\
\text { Radiocomunicação }\end{array}$ \\
\hline Dispositivos & LGT, Art. 173, caput. \\
\hline Revoga & $\begin{array}{l}\text { Resolução da ANATEL no 303/2002 - Aprova o Regulamento sobre Limitação da Exposição a } \\
\text { Campos Elétricos, Magnéticos e Eletromagnéticos na Faixa de Radiofrequeências entre } 9 \mathrm{kHz} \text { e } \\
300 \mathrm{GHz} .\end{array}$ \\
\hline Regulamenta & $\begin{array}{l}\text { Lei n }{ }^{\circ} \text { 9.472/1997 - Dispõe sobre a organização dos serviços de telecomunicações, a criação e } \\
\text { funcionamento de um órgão regulador e outros aspectos institucionais, nos termos da Emenda } \\
\text { Constitucional no } 8, \text { de 1995. }\end{array}$ \\
\hline
\end{tabular}

ARANHA, M.; LIMA, J.; QUELHO, R. Regulação do Setor de Telecomunicações em 2018. Revista de Direito,

Estado e Telecomunicações, v. 11, n. 2, p. 177-230, outubro 2019.

DOI: https://doi.org/10.26512/lstr.v11i2.27083 


\begin{tabular}{|l|l|}
\hline Publicação & Diário Oficial da União, Seção 1,02-10-2018, págs. p. 16-17 \\
\hline Temas & $\begin{array}{l}\text { Temas : Administração do Setor de Telecomunicações : Fiscalização das Telecomunicações } \\
\text { Temas : Infraestrutura e Recursos do Setor de Telecomunicações : Equipamentos de } \\
\text { Telecomunicações }\end{array}$ \\
\hline
\end{tabular}

Resolução da ANATEL $n^{0}$ 701, de 5 de outubro de 2018 - Aprova alteração de Áreas de Tarifação do STFC e do Plano Geral de Códigos Nacionais - PGCN, para (...), aprova alteração de Áreas Locais para o STFC, para excluir o município de Rio Negro-PR da Área Local de Curitiba e aprova alteração de tratamentos locais, em face das alterações anteriores.

\begin{tabular}{|c|c|}
\hline $\begin{array}{lllll}\text { Ó } & \mathrm{r} & \mathrm{g} & \tilde{a} & \mathrm{o} \\
\text { Emissor } & & \end{array}$ & ANATEL - Conselho Diretor. \\
\hline Nota Vigência & 180 dias da publicação no DOU \\
\hline Anexos & $\begin{array}{l}\text { Anexo } 1 \text { - Anexo I - Alteração das Áreas de Tarifação do STFC } \\
\text { Anexo } 2 \text { - Anexo II - Alteração de Códigos Nacionais do PGCN } \\
\text { Anexo } 3 \text { - Anexo III - Alteração de Áreas Locais do STFC } \\
\text { Anexo } 4 \text { - Anexo IV - Exclusões, inclusão e alteração de Tratamentos Locais para o STFC }\end{array}$ \\
\hline Dispositivos & LGT, Art. 64, Parágrafo Único. \\
\hline Altera & $\begin{array}{l}\text { Anexo à Resolução da ANATEL n }{ }^{\circ} 263 \text {, de } 8 \text { de junho de } 2001 \text { - Plano Geral de Códigos } \\
\text { Nacionais - PGCN. } \\
\text { Anexo à Resolução da ANATEL n }{ }^{\circ} 424 \text {, de } 6 \text { de dezembro de } 2005 \text { - Regulamento de Tarifação } \\
\text { do Serviço Telefônico Fixo Comutado Destinado ou Uso do Público em Geral - STFC Prestado } \\
\text { no Regime Público. } \\
\text { Anexo à Resolução da ANATEL no } 560 \text {, de } 21 \text { de janeiro de } 2011 \text { - Regulamento sobre Áreas } \\
\text { Locais para o Serviço Telefônico Fixo Comutado Destinado ao Uso do Público em Geral - } \\
\text { STFC. }\end{array}$ \\
\hline Regulamenta & $\begin{array}{l}\text { Lei } n^{\circ} 9.472 / 1997 \text { - Dispõe sobre a organização dos serviços de telecomunicações, a criação e } \\
\text { funcionamento de um órgão regulador e outros aspectos institucionais, nos termos da Emenda } \\
\text { Constitucional } n^{\circ} 8 \text {, de } 1995 \text {. }\end{array}$ \\
\hline Publicação & Diário Oficial da União, Seção 1, 08-10-2018, págs. p. 36-37 \\
\hline Temas & ecomunicações : Serviço Telefônico Fixo Comutado (STFC) \\
\hline
\end{tabular}

Resolução da ANATEL no 702, de $1^{\circ}$ de novembro de 2018 - Aprova o Regulamento de cobrança de Preço Público pelo Direito de Exploração de Satélite e estabelece o Preço Público para a autorização, a adaptação, a consolidação e a transferência de autorização, permissão e concessão de serviços de telecomunicações.

\begin{tabular}{|c|c|}
\hline $\begin{array}{lllll}\text { Ó } & \mathrm{r} & \mathrm{g} & \tilde{a} & \mathrm{o} \\
\text { Emissor } & & \end{array}$ & ANATEL - Conselho Diretor. \\
\hline Nota Vigência & 180 dias da publicação no DOU \\
\hline Anexos & $\begin{array}{l}\text { Anexo - Anexo - Regulamento de cobrança de Preço Público pelo Direito de Exploração de } \\
\text { Satélite }\end{array}$ \\
\hline Dispositivos & LGT, Art. 172, caput. \\
\hline Revoga & $\begin{array}{l}\text { Resolução da ANATEL no } 386 / 2004 \text { - Aprova o Regulamento de Cobrança de Preço Público } \\
\text { pelo Direito de Exploração de Serviços de Telecomunicações e pelo Direito de Exploração de } \\
\text { Satélite. }\end{array}$ \\
\hline Regulamenta & $\begin{array}{l}\text { Lei } \mathrm{n}^{\circ} 9.472 / 1997 \text { - Dispõe sobre a organização dos serviços de telecomunicações, a criação e } \\
\text { funcionamento de um órgão regulador e outros aspectos institucionais, nos termos da Emenda } \\
\text { Constitucional } n^{\circ} 8 \text {, de } 1995 \text {. }\end{array}$ \\
\hline Publicação & Diário Oficial da União, Seção 1, 05-11-2018, págs. p. 10-11 \\
\hline Temas & $\begin{array}{l}\text { Temas : Administração do Setor de Telecomunicações : Outorgas : Autorização (regras aplicáveis) } \\
\text { Temas : Administração do Setor de Telecomunicações : Outorgas : Concessão (regras aplicáveis) } \\
\text { Temas : Administração do Setor de Telecomunicações : Outorgas : Permissão (regras aplicáveis) }\end{array}$ \\
\hline
\end{tabular}

ARANHA, M.; LIMA, J.; QUELHO, R. Regulação do Setor de Telecomunicações em 2018. Revista de Direito, Estado e Telecomunicações, v. 11, n. 2, p. 177-230, outubro 2019.

DOI: https://doi.org/10.26512/lstr.v11i2.27083 
Temas : Administração do Setor de Telecomunicações : Outorgas : Preço Público e Preço Privado

\begin{tabular}{|c|c|}
\hline $\begin{array}{l}\text { Resolução da } \\
\text { de Espectro de }\end{array}$ & $\begin{array}{l}\text { ANATEL no 703, de } 1^{\circ} \text { de novembro de } 2018 \text { - Estabelece Limites Máximos de Quantidade } \\
\text { Radiofrequências. }\end{array}$ \\
\hline \begin{tabular}{llll|l} 
Ó & $\mathrm{r}$ & $\mathrm{g}$ & $\tilde{\mathrm{a}}$ & $\mathrm{o}$ \\
Emissor & &
\end{tabular} & ANATEL - Conselho Diretor. \\
\hline Nota Vigência & Data de publicação no DOU \\
\hline Anexos & $\begin{array}{l}\text { Anexo - Anexo - Tabelas de subfaixas de radiofrequência abaixo de } 1 \mathrm{GHz} \text { e entre } 1 \mathrm{GHz} \text { e } 3 \\
\mathrm{GHz}\end{array}$ \\
\hline Dispositivos & LGT, Art. 19, inciso VIII; LGT, Art. 157, caput; LGT, Art. 159, caput; LGT, Art. 161, caput. \\
\hline Altera & $\begin{array}{l}\text { Anexo à Resolução da ANATEL } \mathrm{n}^{\circ} 454 \text {, de } 11 \text { de dezembro de } 2006 \text { - Regulamento sobre } \\
\text { Condições de Uso de Radiofreqüências nas Faixas de } 800 \mathrm{MHz}, 900 \mathrm{MHz}, 1.800 \mathrm{MHz}, 1.900 \\
\text { MHz e } 2.100 \mathrm{MHz} \text {. } \\
\text { Anexo à Resolução da ANATEL } \mathrm{n}^{\circ} 537 \text {, de } 17 \text { de fevereiro de } 2010 \text { - Regulamento sobre } \\
\text { Condições de Uso da Faixa de Radiofrequiências de } 3,5 \mathrm{GHz} \text {. } \\
\text { Resolução da ANATEL n } 544 / 2010 \text { - Modificar a Destinação de Radiofrequências nas Faixas } \\
\text { de } 2.170 \mathrm{MHz} \text { a } 2.182 \mathrm{MHz}^{\circ} \text { e de } 2.500 \mathrm{MHz} \text { a } 2.690 \mathrm{MHz} \text { e republicar, com alterações, o } \\
\text { Regulamento sobre Condições de Uso de Radiofrequências nas Faixas de } 2.170 \mathrm{MHz} \text { a } 2.182 \\
\text { MHz e de } 2.500 \mathrm{MHz} \text { a } 2.690 \mathrm{MHz} \text {. } \\
\text { Anexo à Resolução da ANATEL } \mathrm{n}^{\circ} 544 \text {, de } 11 \text { de agosto de } 2010 \text { - Regulamento sobre Condições } \\
\text { de Uso de Radiofreqüências nas Faixas de } 2.170 \mathrm{MHz} \text { a } 2.182 \mathrm{MHz} \text { e de } 2.500 \mathrm{MHz} \text { a } 2.690 \\
\text { MHz. } \\
\text { Anexo - Regulamento sobre Condições de Uso de Radiofrequências na Faixa de } 698 \mathrm{MHz} \text { a } \\
806 \mathrm{MHz} \text { - Regulamento sobre Condições de Uso de Radiofrequências na Faixa de } 698 \mathrm{MHz} \text { a } \\
806 \mathrm{MHz} \text {. }\end{array}$ \\
\hline Regulamenta & $\begin{array}{l}\text { Lei } \mathrm{n}^{\circ} 9.472 / 1997 \text { - Dispõe sobre a organização dos serviços de telecomunicações, a criação e } \\
\text { funcionamento de um órgão regulador e outros aspectos institucionais, nos termos da Emenda } \\
\text { Constitucional } n^{\circ} 8 \text {, de } 1995 \text {. }\end{array}$ \\
\hline Publicação & Diário Oficial da União, Seção 1, 06-11-2018, pág. p. 11 \\
\hline Temas & $\begin{array}{l}\text { Temas : Infraestrutura e Recursos do Setor de Telecomunicações : Espectro de Radiofrequência } \\
\text { : Direito de Uso de Radiofrequência } \\
\text { Temas : Serviços no Setor de Telecomunicações : Serviço Móvel Pessoal (SMP) }\end{array}$ \\
\hline
\end{tabular}

Resolução da ANATEL no 704, de 6 de novembro de 2018 - Altera o Regulamento de Gestão da Qualidade do Serviço de Comunicação Multimídia (RGQ-SCM), aprovado pela Resolução $n^{\circ} 574$, de 28 de outubro de 2011, o Regulamento de Gestão da Qualidade da Prestação do Serviço Móvel Pessoal (RGQ-SMP), aprovado pela Resolução $n^{\circ} 575$, de 28 de outubro de 2011, o Regulamento de Gestão da Qualidade da Prestação do Serviço Telefônico Fixo Comutado (RGQ-STFC), aprovado pela Resolução n ${ }^{\circ} 605$, de 26 de dezembro de 2012, o Regulamento do Serviço de Comunicação Multimídia, aprovado pela Resolução nº 614, de 28 de maio de 2013, e o Regulamento Geral de Direitos do Consumidor de Serviços de Telecomunicações - RGC, Resolução $\mathrm{n}^{\circ} 632$, de 7 de março de 2014.

\begin{tabular}{|c|c|}
\hline $\begin{array}{lllll}\text { Ó } & \mathrm{r} & \mathrm{g} & \tilde{a} & \mathrm{o} \\
\text { Emissor } & & \end{array}$ & ANATEL - Conselho Diretor. \\
\hline Nota Vigência & Data de publicação no DOU \\
\hline Dispositivos & LGT, Art. $2^{\circ}$, inciso III. \\
\hline Regulamenta & $\begin{array}{l}\text { Lei } n^{\circ} 9.472 / 1997 \text { - Dispõe sobre a organização dos serviços de telecomunicações, a criação e } \\
\text { funcionamento de um órgão regulador e outros aspectos institucionais, nos termos da Emenda } \\
\text { Constitucional } n^{\circ} 8 \text {, de } 1995 \text {. }\end{array}$ \\
\hline Publicação & Diário Oficial da União, Seção 1, 09-11-2018, pág. p. 58 \\
\hline Temas & $\begin{array}{l}\text { Temas : Políticas de Telecomunicações : Concorrência no Setor de Telecomunicações } \\
\text { Temas : Serviços no Setor de Telecomunicações : Serviço Móvel Pessoal (SMP) } \\
\text { Temas : Serviços no Setor de Telecomunicações : Serviço Telefônico Fixo Comutado (STFC) }\end{array}$ \\
\hline
\end{tabular}

ARANHA, M.; LIMA, J.; QUELHO, R. Regulação do Setor de Telecomunicações em 2018. Revista de Direito, Estado e Telecomunicações, v. 11, n. 2, p. 177-230, outubro 2019.

DOI: https://doi.org/10.26512/lstr.v11i2.27083 
Temas : Serviços no Setor de Telecomunicações : Serviço de Comunicação Multimídia (SCM)

\begin{tabular}{|l|l|}
\hline $\begin{array}{l}\text { Resolução da ANATEL } \mathbf{n}^{\mathbf{0}} \mathbf{7 0 5} \text {, de } 21 \text { de dezembro de 2018 - Altera o Regulamento sobre Equipamentos de } \\
\text { Radiocomunicação de Radiação Restrita. }\end{array}$ \\
\hline $\begin{array}{l}\text { Ó r g ã o } \\
\text { Emissor }\end{array}$ & ANATEL - Conselho Diretor. \\
\hline Nota Vigência & Data de publicação no DOU \\
\hline Dispositivos & LGT, Art. 161, caput. \\
\hline Altera & $\begin{array}{l}\text { Anexo - Regulamento sobre Equipamentos de Radiocomunicação de Radiação Restrita - Anexo } \\
\text { - Regulamento sobre Equipamentos de Radiocomunicação de Radiação Restrita }\end{array}$ \\
\hline Regulamenta & $\begin{array}{l}\text { Lei no 9.472/1997 - Dispõe sobre a organização dos serviços de telecomunicações, a criação e } \\
\text { funcionamento de um órgão regulador e outros aspectos institucionais, nos termos da Emenda } \\
\text { Constitucional no 8, de 1995. }\end{array}$ \\
\hline Publicação & $\begin{array}{l}\text { Diário Oficial da União, Seção 1, 24-12-2018, págs. p. 6-7 } \\
\text { Temas }\end{array}$ \\
$\begin{array}{l}\text { Temas : Infraestrutura e Recursos do Setor de Telecomunicações : Equipamentos de } \\
\text { Temas : Infraestrutura e Recursos do Setor de Telecomunicações : Espectro de Radiofrequência } \\
\text { Direito de Uso de Radiofrequência }\end{array}$ \\
\hline
\end{tabular}

\section{Julgados Referenciados}

\section{Acórdãos}

\section{Supremo Tribunal Federal (STF)}

\begin{tabular}{|l|l|}
\hline \multicolumn{2}{|l|}{ Ação Direta de Inconstitucionalidade no 4019 (STF ADI 4019 / SP - São Paulo) } \\
\hline Relator & Min. Luiz Fux \\
\hline Órgão Julgador & Plenário do STF \\
\hline Votação & Unânime \\
\hline Julgamento & 13-12-2018 \\
\hline Dispositivos & CF, Art. 22, inciso IV; LGT, Art. $1^{\circ}$, caput. \\
\hline Publicação & Diário da Justiça, 05-02-2019 \\
\hline Temas & $\begin{array}{l}\text { Temas : Atores no Setor de Telecomunicações : Estado-Membro } \\
\text { Temas : Atores no Setor de Telecomunicações : Poder Judiciário : STF } \\
\text { Temas : Serviços no Setor de Telecomunicações : Serviço Telefônico Fixo Comutado (STFC) }\end{array}$ \\
\hline Catalogador & Marcio Iorio Aranha \\
\hline
\end{tabular}

\section{Atos Referenciados}

\section{Ato Administrativo}

\section{Decisão}

\begin{tabular}{|l|l|}
\hline Acórdão do Conselho Diretor da ANATEL, de 3 de janeiro de 2018 (Ref. $\mathbf{n}^{\mathbf{0}} \mathbf{1 1 / 2 0 1 8 )}$ \\
\hline Ementa & $\begin{array}{l}\text { Não há direito à supensão de processos administrativos por descumprimento de obrigações } \\
\text { afetas à prestadora de serviços de telecomunicações em recuperação judicial. }\end{array}$ \\
\hline Órgão Emissor & ANATEL - Conselho Diretor. \\
\hline
\end{tabular}

ARANHA, M.; LIMA, J.; QUELHO, R. Regulação do Setor de Telecomunicações em 2018. Revista de Direito, Estado e Telecomunicações, v. 11, n. 2, p. 177-230, outubro 2019

DOI: https://doi.org/10.26512/lstr.v11i2.27083 


\begin{tabular}{|l|l|}
\hline Dispositivos & LGT, Art. 19, inciso XXV; LGT, Art. 20, Parágrafo Único; LGT, Art. 80, caput. \\
\hline Publicação & Diário Oficial da União, Seção 1, 04-01-2018, pág. p. 3 \\
\hline Temas & Temas : Administração do Setor de Telecomunicações : Fiscalização das Telecomunicações \\
& Temas : Atores no Setor de Telecomunicações : Prestadora / Operadora \\
& Temas : Políticas de Telecomunicações : Universalização : Metas de Universalização \\
\hline
\end{tabular}

\begin{tabular}{|l|l|}
\hline Acórdão do Conselho Diretor da ANATEL, de 20 de dezembro de 2018 (Ref. no 726/2018) \\
\hline Ementa & $\begin{array}{l}\text { Função pública de promoção da integração social por meio do acesso ao conteúdo de TV, } \\
\text { mesmo que inscrita em lei estadual de criação de órgão da Administração Pública com dita } \\
\text { competência, não se sobrepõe ao dever geral de obediência à prévia outorga do direito de uso } \\
\text { de radiofrequência, de competência da União. Mora da Administração Pública federal na } \\
\text { outorga do Serviço de Retransmissão de Televisão (RTV) e consequente uso não autorizado } \\
\text { de radiofrequência na execução não outorgada do RTV não configuram atenuante ou excludente } \\
\text { de ilicitude pela prática de infração de natureza grave, nos termos do art. 80 do Regulamento } \\
\text { de Uso do Espectro de Radiofrequências (RUER/2001), aprovado pela Res. ANATEL no 259, } \\
\text { de 19 de abril de 2001. }\end{array}$ \\
\hline Órgão Emissor & ANATEL - Conselho Diretor. \\
\hline Dispositivos & $\begin{array}{l}\text { CF, Art. 21, inciso XII, alínea a (em 15/08/1995); CF, Art. 223, caput; LGT, Art. 19, inciso } \\
\text { IX; LGT, Art. 19, inciso XXV; LGT, Art. 20, Parágrafo Único; LGT, Art. 163, caput; LGT, } \\
\text { Art. 173, caput; LGT, Art. 211, caput. }\end{array}$ \\
\hline Publicação & Diário Oficial da União, Seção 1, 27-12-2018, pág. p. 42 \\
\hline Temas & $\begin{array}{l}\text { Temas : Administração do Setor de Telecomunicações : Fiscalização das Telecomunicaçães } \\
\text { Temas : Serviços no Setor de Telecomunicações : Radiodifusão : Serviço de Retransmissão } \\
\text { de Televisão (RTV) }\end{array}$ \\
\hline
\end{tabular}




\section{Índice Alfabético e Remissivo}

\section{Símbolos}

3.500 MHz a 3.600 MHz

revogação de atribuição e destinação ao Serviço de Radioamador da faixa de radiofrequência de, $\mathbf{2 1 1}$

[Resolução da ANATEL nº 697/2018]

\section{A}

Ação Direta de Inconstitucionalidade (ver Ação Direta de Inconstitucionalidade (Jurisdição))

Ação Direta de Inconstitucionalidade (Jurisdição)

ADI 4019 / SP

lei estadual é incompetente para determinar a discriminação detalhada nas contas telefônicas das ligações locais, 215

ADI

[STF - ADI 4019 / SP]

(ver Ação Direta de Inconstitucionalidade (Jurisdição))

Administração do Setor de

Telecomunicações, 184

Administração Pública Federal

Política Nacional de Segurança da Informação instituição da, 203

[Decreto $\mathrm{n}^{\circ}$ 9.637, de 26 de dezembro de 2018]

Agência Nacional de Telecomunicações

Alienação de Bens

revogação da Res. 530/2009, que autorizava valores para aquisição ou alienação de bens móveis e imóveis e para contratação de obras e serviços de terceiros pela ANATEL independentemente de anuência do Conselho Diretor, 211

[Resolução da ANATEL nº 696/2018]

Aquisição de Bens

revogação da Res. 530/2009, que autorizava valores para aquisição ou alienação de bens móveis e imóveis e para contratação de obras e serviços de terceiros pela ANATEL independentemente de anuência do Conselho Diretor, 211

[Resolução da ANATEL n 696/2018]

Centro de Altos Estudos em

Telecomunicações

criação do, 208

[Resolução da ANATEL nº 691, de 22 de fevereiro de 2018]

Contratação de Obras

revogação da Res. 530/2009, que autorizava valores para aquisição ou alienação de bens móveis e imóveis e para contratação de obras e serviços de terceiros pela ANATEL independentemente de anuência do Conselho Diretor, 211

[Resolução da ANATEL n ${ }^{\circ}$ 696/2018]

Contratação de Serviços

revogação da Res. 530/2009, que autorizava valores para aquisição ou alienação de bens móveis e imóveis e para contratação de obras e serviços de terceiros pela ANATEL independentemente de anuência do Conselho Diretor, 211

[Resolução da ANATEL n 696/2018]

\section{Alienação de Bens}

revogação da Res. 530/2009, que autorizava valores para aquisição ou alienação de bens móveis e imóveis e para contratação de obras e serviços de terceiros pela ANATEL independentemente de anuência do Conselho Diretor, 211

[Resolução da ANATEL n 696/2018]

ANATEL, 196

(ver Agência Nacional de ANPD

Telecomunicações)

(ver Autoridade Nacional de Proteção de Dados)

\section{Antena}

Regulamento sobre a Avaliação da Exposição Humana a Campos Elétricos, Magnéticos e Eletromagnéticos Associados à Operação de Estações Transmissoras de Radiocomunicação aprovação do, $\mathbf{2 1 2}$

[Resolução da ANATEL n ${ }^{\circ}$ 700/2018]

\section{Aparelho Telefônico}

ARANHA, M.; LIMA, J.; QUELHO, R. Regulação do Setor de Telecomunicações em 2018. Revista de Direito, Estado e Telecomunicações, v. 11, n. 2, p. 177-230, outubro 2019.

DOI: https://doi.org/10.26512/lstr.v11i2.27083 
(ver Telefone Fixo)

Aplicações de Telecomunicações, 194

Aplicações Educacionais, 194

Aquisição de Bens

revogação da Res. 530/2009, que autorizava valores para aquisição ou alienação de bens móveis e imóveis e para contratação de obras e serviços de terceiros pela ANATEL independentemente de anuência do Conselho Diretor, 211

[Resolução da ANATEL nº 696/2018]

Ato de Concentração Econômica (ver Competição)

Atores no Setor de Telecomunicações, 196

Atribuição, Destinação e Distribuição de Radiofrequência, 183

\section{Audiodescrição}

exigência de que a cartela informativa de alteração de canal físico da TV Digital seja dotada de audiodescrição de seu texto feita repetidamente, $\mathbf{2 0 5}$

[Portaria MCTIC $\mathrm{n}^{\circ} 2.105$, de 16 de abril de 2018]

Autoridade Nacional de Proteção de Dados, 200

[Medida Provisória no 869/2018]

competência da, 200

[Medida Provisória no 869/2018]

criação da, 200

[Medida Provisória nº 869/2018]

Autorização (regras aplicáveis), 185

Autorização

condições, critérios e procedimentos de autorização para a execução do RTV, 207

[Portaria MCTIC $\mathrm{n}^{\circ}$ 6.197, de 5 de dezembro de 2018]

Preço Público

disciplina do preço público para autorização, adaptação, consolidação e transferência de autorização, permissão ou concessão de serviços de telecomunicações de interesse coletivo ou restrito, $\mathbf{2 1 3}$

[Resolução da ANATEL n ${ }^{\circ}$ 702/2018]

Autorregulação

Políticas de Telecomunicações orientação para que a ANATEL implemente e execute a regulação do setor de telecomunicações com incentivo à autorregulação e mecanismos correlatos, $\mathbf{2 0 2}$
[Decreto n $\left.{ }^{\circ} 9.612 / 2018\right]$

\section{B}

Banda Larga, 195

Brasil Inteligente, 202

[Decreto $n^{\circ}$ 9.612/2018]

C

Canal de Programação de Distribuição Obrigatória

oferta concomitante de outros serviços de telecomunicações ou SVA ou compartilhamento da Rede não desobriga a prestadora de SeAC a disponibilizar, 209

[Resolução da ANATEL n 692/ 2018]

Ultra High Frequency (Frequiência Ultra Alta)

dispensa da disponibilização dos Canais de Programação de Distribuição Obrigatória de estação de prestadora de SeAC que opera em lagura de banda de $6 \mathrm{MHz}$ na faixa de, 209

[Resolução da ANATEL n ${ }^{\circ}$ 692/ 2018]

Canal de Televisão

(ver Canal de Televisão (Radiodifusão))

Canal de Televisão (Radiodifusão)

exigência de exibição de cartela informativa pelas entidades que executam o serviço de radiodifusão de sons e imagens e o RTV em tecnologia digital que alterarem seu canal físico, 205

[Portaria MCTIC $\mathrm{n}^{\circ} 2.105$, de 16 de abril de 2018]

\section{Canal Virtual}

Transição Analógico-Digital

regras para utilização de canais virtuais pelas entidades executantes dos serviços de radiodifusão de sons e imagens e de retransmissão de televisão do Sistema Brasileiro de Televisão Digital Terrestre - SBTVD$\mathrm{T}, \mathbf{2 0 3}, 205$

[Portaria MCTIC $\mathrm{n}^{\circ} 1.908$, de 6 de abril de 2018] [Portaria MCTIC nº 699, de 6 de fevereiro de 2018]

\section{Caráter Primário}

ARANHA, M.; LIMA, J.; QUELHO, R. Regulação do Setor de Telecomunicações em 2018. Revista de Direito, Estado e Telecomunicações, v. 11, n. 2, p. 177-230, outubro 2019.

DOI: https://doi.org/10.26512/lstr.v11i2.27083 
(ver Uso em Caráter Primário (Radiofreqüiência))

Ceatel, 208

[Resolução da ANATEL no 691, de 22 de fevereiro de 2018]

Celular

(ver Telefone Fixo)

Celular

Regulamento sobre a Avaliação da

Exposição Humana a Campos Elétricos, Magnéticos e Eletromagnéticos

Associados à Operação de Estações

Transmissoras de Radiocomunicação aprovação do, 212

[Resolução da ANATEL n ${ }^{\circ}$ 700/2018]

Centro de Altos Estudos em

Telecomunicações

criação do, 208

[Resolução da ANATEL nº 691, de 22 de fevereiro de 2018]

Cidade Digital

Políticas de Telecomunicações dispõe sobre as, $\mathbf{2 0 2}$

[Decreto ${ }^{\circ}$ 9.612/2018]

Cidade Inteligente

Políticas de Telecomunicações

dispõe sobre as, $\mathbf{2 0 2}$

[Decreto no 9.612/2018]

CITDigital

(ver Comitê Interministerial para a Transformação Digital)

CITDigital, 200

[Decreto $n^{\circ}$ 9.319/2018]

Coletivo

(ver Serviço de Interesse Coletivo)

Comitê de Prestadoras de Pequeno Porte de Serviços de Telecomunicações junto à ANATEL

instituição do, 212

[Resolução da ANATEL no ${ }^{\circ}$ 698/2018]

Comitê Interministerial para

Transformação Digital

criação do, 200

[Decreto $n^{\circ}$ 9.319/2018]

Compartilhamento de Infraestrutura, 182

Compartilhamento de Infraestrutura

Política Nacional de Segurança da

Informação

dever de priorização da interoperabilidade de tecnologias, processos, informações e dados, com a promoção da integração e do compartilhamento de redes de telecomunicações da administração pública federal direta, autárquica e fundacional, 203

[Decreto $\mathrm{n}^{\circ} 9.637$, de 26 de dezembro de 2018]

\section{Competição}

categorias de concentração de mercado nos municípios, 209

[Resolução da ANATEL nº 694/2018]

Conceitos Fundamentais, 182

Concentração de Mercado

categorias de concentração de mercado nos municípios, 209

[Resolução da ANATEL no 694/2018]

Concessão (regras aplicáveis), 185

Concessão

Preço Público

disciplina do preço público para autorização, adaptação, consolidação e transferência de autorização, permissão ou concessão de serviços de telecomunicações de interesse coletivo ou restrito, $\mathbf{2 1 3}$

[Resolução da ANATEL no 702/2018]

Radiodifusão Educativa

condições e procedimentos de permissão e concessão para a execução dos serviços de radiodifusão sonora em frequência modulada e de sons e imagens, com fins exclusivamente educativos, 206

[Portaria MCTIC n 3.238, de 20 de junho de 2018]

Concorrência

(ver Competição)

Concorrência no Setor de

Telecomunicações, 186

Condições de Uso de Radiofrequência e

Canalização (Distribuição de Canais), 183

a Conta Telefônica

ADI 4019 / SP

lei estadual é incompetente para determinar a discriminação detalhada nas contas telefônicas das ligações locais, 215

[STF - ADI 4019 / SP]

\section{Conteúdo Local}

Serviço de Retransmissão de Rádio (RTR) na Amazônia Legal

limites à inserção de programação local no, 199

ARANHA, M.; LIMA, J.; QUELHO, R. Regulação do Setor de Telecomunicações em 2018. Revista de Direito, Estado e Telecomunicações, v. 11, n. 2, p. 177-230, outubro 2019

DOI: https://doi.org/10.26512/lstr.v11i2.27083 
[Lei no 13.649/2018]

\section{Contratação de Obras}

revogação da Res. 530/2009, que autorizava valores para aquisição ou alienação de bens móveis e imóveis e para contratação de obras e serviços de terceiros pela ANATEL independentemente de anuência do Conselho Diretor, 211

[Resolução da ANATEL nº 696/2018]

\section{Contratação de Serviços}

revogação da Res. 530/2009, que autorizava valores para aquisição ou alienação de bens móveis e imóveis e para contratação de obras e serviços de terceiros pela ANATEL independentemente de anuência do Conselho Diretor, 211

[Resolução da ANATEL n n 696/2018]

\section{Conversor de TV Digital Terrestre}

Redistribuição e Digitalização de Canais de TV e RTV

destinação de saldo remanescente relativo ao ressarcimento dos custos decorrentes da, 206

[Portaria MCTIC n ${ }^{\circ} 3.045$, de 7 de junho de 2018]

\section{CPPP}

(ver Comitê de Prestadoras de Pequeno Porte de Serviços de Telecomunicações junto à ANATEL)

\section{D}

\section{Dado Pessoal}

dispõe sobre a proteção de dados pessoais e operações de tratamento de dados pessoais independentemente do meio, 199

\section{Dados, 199}

$$
\text { [Lei }{ }^{\circ} \text { 13.709/2018] }
$$

[Lei $\left.{ }^{\circ} 13.709 / 2018\right]$

\section{Dano à Saúde}

Regulamento sobre a Avaliação da Exposição Humana a Campos Elétricos, Magnéticos e Eletromagnéticos Associados à Operação de Estações Transmissoras de Radiocomunicação aprovação do, 212 [Resolução da ANATEL n n 700/2018]

\section{Defesa do Usuário}

(ver Usuário)

Deficiência Visual

Audiodescrição

exigência de que a cartela informativa de alteração de canal físico da TV Digital seja dotada de audiodescrição de seu texto feita repetidamente, $\mathbf{2 0 5}$ [Portaria MCTIC $\mathrm{n}^{\circ} 2.105$, de 16 de abril de 2018]

Digitalização

(ver também TV Digital)

Radiodifusão

destinação de saldo remanescente relativo ao ressarcimento dos custos decorrentes da redistribuição e digitalização de canais de TV e RTV, 206

[Portaria MCTIC n ${ }^{\circ} 3.045$, de 7 de junho de 2018]

exigência de exibição de cartela informativa pelas entidades que executam o serviço de radiodifusão de sons e imagens e o RTV em tecnologia digital que alterarem seu canal físico, $\mathbf{2 0 5}$

[Portaria MCTIC n ${ }^{\circ} 2.105$, de 16 de abril de 2018]

regras para utilização de canais virtuais pelas entidades executantes dos serviços de radiodifusão de sons e imagens e de retransmissão de televisão do Sistema Brasileiro de Televisão Digital Terrestre - SBTVDT, 203, 205

[Portaria MCTIC $\mathrm{n}^{\circ} 1.908$, de 6 de abril de 2018] [Portaria MCTIC n 699, de 6 de fevereiro de 2018]

Direito à Privacidade, 182

Direito Administrativo, 194

Direito de Uso de Radiofrequência, 183

Direito Penal, 194

Disque Denúncia

disciplina de recompensas por informações em investigações policiais, possibilidade de uso do Fundo Nacional de Segurança Pública e obrigatoriedade de divulgação do Disque-Denúncia em frotas de concessionárias de transportes terrestres, 198

[Lei ${ }^{\circ} 13.608$, de 10 de janeiro de 2018] 
E

E-Digital

(ver Estratégia Brasileira para a Transformação Digital)

E-Digital, 200

[Decreto n ${ }^{\circ}$ 9.319/2018]

Equipamento de Radiação Restrita (ver Equipamento de Radiocomunicação de Radiação Restrita)

Equipamento de Radiocomunicação de Radiação Restrita, 215

[Resolução da ANATEL n ${ }^{\circ}$ 705/ 2018]

Regulamento sobre Equipamentos de

Radiocomunicação de Radiação Restrita, 215

[Resolução da ANATEL n ${ }^{\circ}$ 705/ 2018]

Equipamentos de Telecomunicações, 183

Era da Informação, 182

Espécies de Outorga, 185

Espectro de Radiofrequência, 183

Espectro de Radiofreqüências

limites máximos de quantidade de, 214

[Resolução da ANATEL no 703/2018]

Estação do Serviço de Radioamador disciplina do licenciamento da, $\mathbf{2 1 1}$

[Resolução da ANATEL nº 697/2018]

Estado-Membro, 198

Estado-Membro

Conta Telefônica

lei estadual é incompetente para determinar a discriminação detalhada nas contas telefônicas das ligações locais, 215

[STF - ADI 4019 / SP]

Estratégia Brasileira para a Transformação Digital

(ver também Rede Nacional de Governo Digital)

definição e objetivos da, 200

[Decreto $n^{\circ}$ 9.319/2018]

Execução Indireta

(ver Execução Indireta (Lei Geral de Licitações))

Execução Indireta (Lei Geral de Licitações) disciplina da execução indireta, mediante contratação, de serviços da administração pública federal direta, autárquica e fundacional e das empresas públicas e das sociedades de economia mista controladas pela União, 201
[Decreto $\mathrm{n}^{\circ} 9.507$, de 21 de setembro de 2018]

Exposição Humana a Campos Elétricos, Magnéticos e Eletromagnéticos

Regulamento sobre a Avaliação da Exposição Humana a Campos Elétricos, Magnéticos e Eletromagnéticos Associados à Operação de Estações Transmissoras de Radiocomunicação aprovação do, 212 [Resolução da ANATEL n 700/2018]

F

Faixa de Radiofreqüência (ver Espectro de Radiofreqüiências)

Fiscalização das Telecomunicações, 184 FISTEL

(ver Fundo de Fiscalização das FM Telecomunicações)

(ver Frequência Modulada)

FNSP

(ver Fundo Nacional de Segurança Pública)

Frequência Modulada

Rádio AM

novo prazo para manifestação de interesse na adaptação de outorga do serviço de radiodifusão sonora em onda média para a execução do serviço de radiodifusão em frequência modulada, 200

[Decreto $\left.n^{\circ} 9.270 / 2018\right]$

Rádio FM

novo prazo para manifestação de interesse na adaptação de outorga do serviço de radiodifusão sonora em onda média para a execução do serviço de radiodifusão em frequência modulada, 200

[Decreto $\left.\mathrm{n}^{\circ} 9.270 / 2018\right]$

Fundamentos, 182

Fundo de Fiscalização das

Telecomunicações, 207

(ver também Receita Administrada)

[Resolução da ANATEL nº 690/2018]

Fundo de Universalização dos Serviços de Telecomunicações, 207

(ver também Universalização)

[Resolução da ANATEL nº 690/2018]

ARANHA, M.; LIMA, J.; QUELHO, R. Regulação do Setor de Telecomunicações em 2018. Revista de Direito, Estado e Telecomunicações, v. 11, n. 2, p. 177-230, outubro 2019.

DOI: https://doi.org/10.26512/lstr.v11i2.27083 
Fundo Nacional de Segurança Pública

Disque Denúncia

sua inclusão como projeto passível de apoio por parte do Fundo Nacional de Segurança Pública, 198

[Lei n ${ }^{\circ} 13.608$, de 10 de janeiro de 2018]

Fundos Setoriais de Telecomunicações, 187 FUST

(ver Fundo de Universalização dos Serviços de Telecomunicações)

\section{G}

Governança Digital, 196

Governo Estadual (ver Estado-Membro)

Governo Municipal

(ver Município)

\section{H}

Horário de Retransmissão Obrigatória do Programa Oficial dos Poderes da República, 198

[Lei n ${ }^{\circ}$ 13.644/2018]

Infração Penal

Polícia Federal

sua competência para investigar crimes praticados por meio da rede mundial de computadores que difundam conteúdo misógino, 198

[Lei ${ }^{\circ}$ 13.642/ 2018]

Infraestrutura de Telecomunicações, 182

Infraestrutura e Recursos do Setor de Telecomunicações, 182

Inserção Local de Programação, 199

[Lei no 13.649/2018]

Inserção Local de Publicidade, 199

[Lei no 13.649/2018]

Interconexão, 183

Interconexão, 209

(ver também Regulamento Geral de Interconexão)

[Resolução da ANATEL n 693/2018]

Interesse Coletivo (ver Serviço de Interesse Coletivo)

Interesse Coletivo, 213 (ver também Serviço de Interesse Coletivo)

[Resolução da ANATEL n ${ }^{\circ}$ 702/2018]

Interesse Restrito

ARANHA, M.; LIMA, J.; QUELHO, R. Regulação do Setor de Telecomunicações em 2018. Revista de Direito, Estado e Telecomunicações, v. 11, n. 2, p. 177-230, outubro 2019.

DOI: https://doi.org/10.26512/lstr.v11i2.27083 (ver Serviço de Interesse Restrito)

Internet, 188, 195

INTERNET

(ver também Serviço de Valor Adicionado)

dispõe sobre a proteção de dados pessoais e operações de tratamento de dados pessoais independentemente do meio, 199

[Lei $n^{\circ}$ 13.709/2018]

Polícia Federal

sua competência para investigar crimes praticados por meio da rede mundial de computadores que difundam conteúdo misógino, 198

[Lei n ${ }^{\circ}$ 13.642/ 2018]

L

Legislação de Telecomunicações

lei estadual é incompetente para determinar a discriminação detalhada nas contas telefônicas das ligações locais, 215 [STF - ADI 4019 / SP]

M

Marco Civil da Internet

altera o rol de exceções ao direito do usuário da internet de exclusão definitiva dos dados pessoais que tiver fornecido a determinada apliação de internet, 199

[Lei $\mathrm{n}^{\circ}$ 13.709/2018]

Metas de Universalização, 187

Metas de Universalização

(ver também Plano Geral de Metas de Universalização)

Recuperação Judicial

o processamento administrativo por descumprimento de metas de universalização não é suspenso pela condição de a prestadora estar em recuperação judicial, 215

[Acórdão do Conselho Diretor da ANATEL, de 3 de janeiro de 2018 (Ref. no 11/2018)]

Ministério da Ciência, Tecnologia, Inovações e Comunicações, 196

Ministério do Planejamento, Orçamento e Gestão, 197

Modelagem Regulatória

Autorregulação

orientação para que a ANATEL implemente e execute a regulação do 
setor de telecomunicações com incentivo à autorregulação e mecanismos correlatos, $\mathbf{2 0 2}$

[Decreto ${ }^{\circ}$ 9.612/2018]

\section{Mora Administrativa}

dela não resulta excludente de ilicitude ou atenuante ao uso não autorizado de radiofrequência na execução não outorgada do Serviço de Retransmissão de Televisão (RTV), 216

[Acórdão do Conselho Diretor da ANATEL, de 20 de dezembro de 2018 (Ref. $n^{\circ}$ 726/2018)]

\section{Multa}

seu valor máximo por infração às disposições legais e regulamentares aos serviços de radiodifusão e seus ancilares, 203

\section{Município}

[Portaria MCTIC n ${ }^{\circ} 353$, de 19 de janeiro de 2018]

categorias de concentração de mercado nos municípios, 209

[Resolução da ANATEL nº 694/2018]

\section{0}

\section{Obrigações de Universalização} (ver Universalização)

\section{$\mathbf{P}$}

Permissão (regras aplicáveis), 185

Permissão

Preço Público

disciplina do preço público para autorização, adaptação, consolidação

e transferência de autorização, permissão ou concessão de serviços de telecomunicações de interesse coletivo ou restrito, $\mathbf{2 1 3}$

[Resolução da ANATEL nº 702/2018]

Radiodifusão Educativa

condições e procedimentos de permissão e concessão para a execução dos serviços de radiodifusão sonora em frequência modulada e de sons e imagens, com fins exclusivamente educativos, 206

[Portaria MCTIC $\mathrm{n}^{\circ} 3.238$, de 20 de junho de 2018]

Pesquisa \& Desenvolvimento, 187

PGCN

(ver Plano Geral de Códigos Nacionais)

PGMU

(ver Plano Geral de Metas de

Universalização)

Plano Geral de Códigos Nacionais alteração do, $\mathbf{2 1 3}$

[Resolução da ANATEL no 701/2018]

Plano Geral de Metas de Universalização (ver também Metas de Universalização) a partir de, $\mathbf{2 0 2}$

[Decreto n ${ }^{\circ}$ 9.619/2018]

Plano Geral de Metas de Universalização do STFC no Regime Público (ver também Universalização)

o processamento administrativo por descumprimento de metas de universalização não é suspenso pela condição de a prestadora estar em recuperação judicial, 215

[Acórdão do Conselho Diretor da ANATEL, de 3 de janeiro de 2018 (Ref. $n^{\circ} 11 / 2018$ )]

Plano Nacional de Outorgas de Radiodifusão Educativa (PNO-Educ) (ver PNO-Educ)

Plano Nacional de Outorgas de Radiodifusão Educativa (PNO-Educ)

sua divulgação periódico e diretrizes, 206

[Portaria MCTIC n ${ }^{\circ} 3.238$, de 20 de junho de 2018]

PNBL

(ver Programa Nacional de Banda Larga)

PNO-Educ, 206

[Portaria MCTIC n 3.238, de 20 de junho de 2018]

PNSI, 203

[Decreto ${ }^{\circ}$ 9.637, de 26 de dezembro de 2018]

Poder Executivo, 196

Poder Judiciário, 197

Política Nacional de Segurança da Informação

instituição da, 203

[Decreto $\mathrm{n}^{\circ} 9.637$, de 26 de dezembro de 2018]

Política Pública de Telecomunicações

(ver Políticas de Telecomunicações)

Políticas de Telecomunicações, 186

Políticas de Telecomunicações dispõe sobre as, $\mathbf{2 0 2}$

[Decreto $n^{\circ}$ 9.612/2018]

\section{Políticas Setoriais}

ARANHA, M.; LIMA, J.; QUELHO, R. Regulação do Setor de Telecomunicações em 2018. Revista de Direito, Estado e Telecomunicações, v. 11, n. 2, p. 177-230, outubro 2019.

DOI: https://doi.org/10.26512/lstr.v11i2.27083 
(ver Políticas de Telecomunicações)

PPDUR

(ver Preço Público pelo Direito de Uso de Radiofrequências)

Preço Público

disciplina do preço público para autorização, adaptação, consolidação e transferência de autorização, permissão ou concessão de serviços de telecomunicações de interesse coletivo ou restrito, $\mathbf{2 1 3}$

[Resolução da ANATEL n ${ }^{\circ}$ 702/2018]

Preço Público e Preço Privado, 186

Preço Público pelo Direito de Uso de Radiofrequências

Regulamento de Cobrança de Preço Público pelo Direito de Uso de Radiofrequências aprovação do, $\mathbf{2 1 0}$

[Resolução da ANATEL n ${ }^{\circ}$ 695/2018]

Presidência da República, 196

Prestação de Serviços, 185

Prestadora / Operadora, 197

Prestadora de Pequeno Porte

Comitê de Prestadoras de Pequeno Porte de Serviços de Telecomunicações junto à ANATEL instituição do, 212

[Resolução da ANATEL no 698/2018]

uniformização do conceito de prestadora de pequeno porte, 214

[Resolução da ANATEL n ${ }^{\circ}$ 704/2018]

Princípio da Generalidade

(ver Universalização)

Processo Administrativo

racionalização de atos e procedimentos do, 199

[Lei ${ }^{\circ}$ 13.726/2018]

Programa Brasil Inteligente

(ver Brasil Inteligente)

Programa Brasil Inteligente extinção do, 202

[Decreto ${ }^{\circ}$ 9.612/2018]

Programa Nacional de Banda Larga extinção do, 202

[Decreto n ${ }^{\circ}$ 9.612/2018]

Programação Local

(ver Inserção Local de Programação)

Programação Local

Serviço de Retransmissão de Rádio (RTR) na Amazônia Legal limites à inserção local de programação no, 199

[Lei $n^{\circ}$ 13.649/2018]

\section{Propaganda}

(ver Publicidade)

Proteção do Usuário

(ver Usuário)

Publicidade, 199

[Lei $\mathrm{n}^{\circ} 13.649 / 2018$ ]

Publicidade Local

(ver Inserção Local de Publicidade)

Publicidade Local

Serviço de Retransmissão de Rádio (RTR)

na Amazônia Legal

limites à inserção local de publicidade no, 199

[Lei $\left.\mathrm{n}^{\circ} 13.649 / 2018\right]$

$\mathbf{R}$

Radioamador, 188

Radioamador

faixas de radiofrequência do, 211

[Resolução da ANATEL nº 697/2018]

Regulamento sobre Condições de Uso de

Radiofreqüências pelo Serviço de

Radioamador

aprovação do, 211

[Resolução da ANATEL nº 697/2018]

Radioamador por Satélite

faixas de radiofrequências do, 211

[Resolução da ANATEL nº 697/2018]

Radiodifusão, 189

Radiodifusão

(ver também Radiodifusão Comunitária)

(ver também Radiodifusão Educativa)

(ver também Serviço de Retransmissão de

Rádio)

Adaptação de Outorga

prazo para manifestação de interesse na adaptação de outorga do serviço de radiodifusão sonora em onda média para a execução do serviço de radiodifusão em frequência modulada, 200

Multa

[Decreto $n^{\circ} 9.270 / 2018$ ]

seu valor máximo por infração às disposições legais e regulamentares aos serviços de radiodifusão e seus ancilares, 203 
[Portaria MCTIC no 353, de 19 de janeiro de 2018]

Redistribuição e Digitalização de Canais de TV e RTV

destinação de saldo remanescente relativo ao ressarcimento dos custos decorrentes da, 206

[Portaria MCTIC n 3.045 , de 7 de junho de 2018]

Serviço de Retransmissão de Televisão condições, critérios e procedimentos de autorização para a execução do RTV, 207

[Portaria MCTIC $\mathrm{n}^{\circ}$ 6.197, de 5 de dezembro de 2018]

Voz do Brasil

definição do horário de retransmissão da, 198

[Lei $n^{\circ} 13.644 / 2018$ ]

Radiodifusão Comunitária

(ver também Radiodifusão)

Plano Nacional de Outorgas para o Serviço de Radiodifusão Comunitária aprovação do, 204

[Portaria MCTIC $\mathrm{n}^{\circ} 720$, de 7 de fevereiro de 2018]

Processo Administrativo regulamentação do, 204-205

[Portaria MCTIC n ${ }^{\circ} 1.909$, de 5 de abril de 2018] [Portaria MCTIC n ${ }^{\circ} 1.976$, de 12 de abril de 2018]

Radiodifusão Educativa

(ver também Radiodifusão)

condições e procedimentos de permissão e concessão para a execução dos serviços de radiodifusão sonora em frequência modulada e de sons e imagens, com fins exclusivamente educativos, 206

[Portaria MCTIC n 3.238, de 20 de junho de 2018]

Radiofreqüência

(ver Espectro de Radiofreqüiências)

Ramos Jurídicos Afins, 194

Reajuste Tarifário

(ver também Serviço Telefônico Fixo Comutado)

inclusão de dever à prestadora de serviços de telecomunicações para que divulgue os reajustes realizados nos últimos cinco anos, 199

[Lei $\left.{ }^{\circ} 13.673 / 2018\right]$ (ver também Fundo de Fiscalização das

Telecomunicações)

(ver também Tributo)

Compensação de Receita Administrada regulamentação da, $\mathbf{2 0 7}$

[Resolução da ANATEL n ${ }^{\circ}$ 690/2018]

Restituição de Receita Administrada regulamentação da, 207

[Resolução da ANATEL n 690/2018]

\section{Recuperação Judicial}

o processamento administrativo por descumprimento de metas de universalização não é suspenso pela condição de a prestadora estar em recuperação judicial, 215

[Acórdão do Conselho Diretor da ANATEL, de 3 de janeiro de 2018 (Ref. $n^{\circ} 11 / 2018$ )]

Rede Gov.Br, 201

[Decreto ${ }^{\circ}$ 9.584/2018]

Rede Nacional de Governo Digital, 201

(ver também Estratégia Brasileira para a Transformação Digital)

[Decreto ${ }^{\circ}$ 9.584/2018]

instituição da, 201

[Decreto $n^{\circ}$ 9.584/2018]

Redes de Telecomunicações, 183

Redistribuição e Digitalização de Canais de TV e RTV

destinação de saldo remanescente relativo ao ressarcimento dos custos decorrentes da, 206

[Portaria MCTIC n ${ }^{\circ} 3.045$, de 7 de junho de 2018]

Regulador

Centro de Altos Estudos em

Telecomunicações

criação do, 208

[Resolução da ANATEL nº 691, de 22 de fevereiro de 2018]

Regulamento de Cobrança de Preço Público pelo Direito de Uso de Radiofrequências aprovação do, 210

[Resolução da ANATEL n ${ }^{\circ}$ 695/2018]

Regulamento de Restituição e Compensação das Receitas Administradas pela ANATEL

aprovação do, 207

[Resolução da ANATEL n 690/2018]

Regulamento de Tarifação do STFC

alteração do, 213

[Resolução da ANATEL n ${ }^{\circ}$ 701/2018]

\section{Receita Administrada}

ARANHA, M.; LIMA, J.; QUELHO, R. Regulação do Setor de Telecomunicações em 2018. Revista de Direito, Estado e Telecomunicações, v. 11, n. 2, p. 177-230, outubro 2019.

DOI: https://doi.org/10.26512/lstr.v11i2.27083 
Regulamento do Serviço de Retransmissão de Televisão e do Serviço de Repetição de Televisão

alteração do, 201

[Decreto $\mathrm{n}^{\circ} 9.479$, de 22 de agosto de 2018]

Regulamento Geral de Interconexão

(ver também Interconexão)

aprovação do, 209

[Resolução da ANATEL nº 693/2018]

Regulamento sobre a Avaliação da Exposição Humana a Campos Elétricos, Magnéticos e Eletromagnéticos Associados à Operação de Estações Transmissoras de Radiocomunicação aprovacao do, 212

[Resolução da ANATEL no 700/2018]

Regulamento sobre Áreas Locais para o STFC

alteração do, 212-213

[Resolução da ANATEL no 699/2018]

[Resolução da ANATEL nº 701/2018]

Regulamento sobre Condições de Uso de

Radiofreqüências pelo Serviço de

Radioamador

aprovação do, 211

[Resolução da ANATEL nº 697/2018]

Regulamento sobre Equipamentos de

Radiocomunicação de Radiação Restrita, 215

[Resolução da ANATEL nº 705/ 2018]

Restrito

(ver Serviço de Interesse Restrito)

Retransmissão de TV

(ver Serviço de Retransmissão de Televisão)

Risco à Saúde

Regulamento sobre a Avaliação da Exposição Humana a Campos Elétricos, Magnéticos e Eletromagnéticos Associados à Operação de Estações Transmissoras de Radiocomunicação aprovação do, 212

RTR

[Resolução da ANATEL n ${ }^{\circ}$ 700/2018]

(ver Serviço de Retransmissão de Rádio) (ver Serviço de Retransmissão de Televisão)

S

Sanção

Mora Administrativa

dela não resulta excludente de ilicitude ou atenuante ao uso não autorizado de radiofrequência na execução não outorgada do Serviço de Retransmissão de Televisão (RTV), 216

[Acórdão do Conselho Diretor da ANATEL, de 20 de dezembro de 2018 (Ref. $n^{\circ}$ 726/2018)]

Saúde

Regulamento sobre a Avaliação da Exposição Humana a Campos Elétricos, Magnéticos e Eletromagnéticos Associados à Operação de Estações

Transmissoras de Radiocomunicação aprovação do, $\mathbf{2 1 2}$

SCM [Resolução da ANATEL n ${ }^{\circ}$ 700/2018]

(ver Serviço de Comunicação Multimídia) Serviço de Acesso Condicionado (SeAC), 191

Serviço de Acesso Condicionado

Concentração de Mercado categorias de concentração de mercado nos municípios, 209

[Resolução da ANATEL n ${ }^{\circ}$ 694/2018]

definições de capacidade útil total, grade de programação e ponto de entrega dos sinais da programação, 209

[Resolução da ANATEL nº 692/ 2018]

Serviço de Valor Adicionado sua oferta concomitante ao SeAC não desobriga a prestadora de SeAC a disponibilizar os Canais de Programação de Distribuição Obrigatória, 209

[Resolução da ANATEL n ${ }^{\circ}$ 692/ 2018]

Unidade Receptora Decodificadora direito à URD que permita a utilização de recursos de acessibilidade no SeAC, 209

[Resolução da ANATEL nº 692/ 2018] 
Serviço de Comunicação Multimída (SCM), 191

Serviço de Comunicação Multimídia

Concentração de Mercado

categorias de concentração de mercado nos municípios, 209

[Resolução da ANATEL no 694/2018]

Prestadora de Pequeno Porte

uniformização do conceito de prestadora de pequeno porte, 214

[Resolução da ANATEL nº 704/2018]

Serviço de Interesse Coletivo

(ver também Interesse Coletivo)

Preço Público

disciplina do preço público para autorização, adaptação, consolidação e transferência de autorização, permissão ou concessão de serviços de telecomunicações de interesse coletivo ou restrito, $\mathbf{2 1 3}$

[Resolução da ANATEL n ${ }^{\circ}$ 702/2018]

Serviço de Interesse Restrito

Preço Público

disciplina do preço público para autorização, adaptação, consolidação e transferência de autorização, permissão ou concessão de serviços de telecomunicações de interesse coletivo ou restrito, $\mathbf{2 1 3}$

[Resolução da ANATEL n ${ }^{\circ}$ 702/2018]

Serviço de Radioamador

(ver Radioamador)

Serviço de Radiodifusão, 188

Serviço de Radiodifusão de Sons e Imagens (ver Radiodifusão)

Serviço de Radiodifusão Sonora

(ver Radiodifusão)

Serviço de Repetição de Televisão (RpTV), 191

Serviço de Retransmissão de Rádio (RTR), 190

Serviço de Retransmissão de Rádio, 199 (ver também Radiodifusão)

[Lei ${ }^{\circ}$ 13.649/2018]

Serviço de Retransmissão de Rádio (RTR)

na Amazônia Legal

disciplina do, 199

[Lei no 13.649/2018]

Serviço de Retransmissão de Televisão (RTV), 190

Serviço de Retransmissão de Televisão Autorização condições, critérios e procedimentos de autorização para a execução do RTV, 207

[Portaria MCTIC $\mathrm{n}^{\circ}$ 6.197, de 5 de dezembro de 2018]

Mora Administrativa

dela não resulta excludente de ilicitude ou atenuante ao uso não autorizado de radiofrequência na execução não outorgada do Serviço de Retransmissão de Televisão (RTV), 216

[Acórdão do Conselho Diretor da ANATEL, de 20 de dezembro de $2018{\text { (Ref. }{ }^{\circ}}^{\circ}$ 726/2018)]

Serviço de Valor Acrescentado

(ver Serviço de Valor Adicionado)

Serviço de Valor Acrescido

(ver Serviço de Valor Adicionado)

Serviço de Valor Adicionado

(ver também INTERNET)

sua oferta concomitante ao SeAC não desobriga a prestadora de $\operatorname{SeAC}$ a disponibilizar os Canais de Programação de Distribuição Obrigatória, 209

[Resolução da ANATEL n 692/ 2018]

Serviço Móvel Pessoal (SMP), 192

Serviço Móvel Pessoal

Concentração de Mercado

categorias de concentração de mercado nos municípios, 209

[Resolução da ANATEL nº 694/2018]

Espectro de Radiofreqüências limites máximos de quantidade de, 214

[Resolução da ANATEL n ${ }^{\circ}$ 703/2018]

Prestadora de Pequeno Porte

uniformização do conceito de prestadora de pequeno porte, $\mathbf{2 1 4}$

[Resolução da ANATEL n ${ }^{\circ}$ 704/2018]

Serviço Telefônico Fixo Comutado (STFC), 193

Serviço Telefônico Fixo Comutado, 193

(ver também Reajuste Tarifário)

Plano Geral de Outorgas

alteração do, 213

[Resolução da ANATEL n ${ }^{\circ}$ 701/2018]

Prestadora de Pequeno Porte

uniformização do conceito de prestadora de pequeno porte, 214

[Resolução da ANATEL nº 704/2018]

ARANHA, M.; LIMA, J.; QUELHO, R. Regulação do Setor de Telecomunicações em 2018. Revista de Direito, Estado e Telecomunicações, v. 11, n. 2, p. 177-230, outubro 2019.

DOI: https://doi.org/10.26512/1str.v11i2.27083 
Serviços no Setor de Telecomunicações, 188 Sigilo

Política Nacional de Segurança da Informação instituição da, 203

[Decreto $\mathrm{n}^{\circ} 9.637$, de 26 de dezembro de 2018]

Sigilo em Telecomunicações, 188

SinDigital, 200

[Decreto $n^{\circ}$ 9.319/2018]

Sistema Nacional para a Transformação Digital (SinDigital)

(ver SinDigital)

Sistema Nacional para a Transformação Digital

instituição do, 200

[Decreto nº 9.319/2018]

Sistema TELEBRAS

(ver Telecomunicações Brasileiras S.A.)

SMP

(ver Serviço Móvel Pessoal)

STF, 197

(ver Supremo Tribunal Federal)

STFC

(ver Serviço Telefônico Fixo Comutado)

Supremo Tribunal Federal

lei estadual é incompetente para determinar a discriminação detalhada nas contas telefônicas das ligações locais, 215

SVA [STF - ADI 4019 / SP]

\section{(ver Serviço de Valor Adicionado)}

$\mathbf{T}$

\section{TELEBRAS}

(ver Telecomunicações Brasileiras S.A.)

Telecomunicações Brasileiras S.A.

Rede Privativa de Comunicação da Administração Pública Federal

mantida a atribuição de sua implementação após substituição do Programa Nacional de Banda Larga e do Programa Brasil Inteligente pelas políticas públicas de telecomunicações aprovadas pelo Decreto 9.612, de 17 de dezembro de 2018, 202

[Decreto $\left.n^{\circ} 9.612 / 2018\right]$

Universidade

mantida a atribuição de prestação de apoio e suporte às políticas públicas de conexão à internet em banda larga para universidades, centros de pesquisa, escolas, hospitais, postos de atendimento, tele centros comunitários e outros pontos de interesse público após substituição do Programa Nacional de Banda Larga e do Programa Brasil Inteligente pelas políticas públicas de telecomunicações aprovadas pelo Decreto 9.612, de 17 de dezembro de 2018, 202

[Decreto $\left.n^{\circ} 9.612 / 2018\right]$

\section{Telefone Fixo}

Regulamento sobre a Avaliação da Exposição Humana a Campos Elétricos, Magnéticos e Eletromagnéticos Associados à Operação de Estações Transmissoras de Radiocomunicação aprovação do, 212

[Resolução da ANATEL no 700/2018]

Televisão Digital

(ver TV Digital)

Transporte Terrestre

obrigatoriedade de divulgação do DisqueDenúncia em frotas de concessionárias de transportes terrestres, 198

[Lei n ${ }^{\circ} 13.608$, de 10 de janeiro de 2018]

Tributação no Setor de Telecomunicações, 184

Tributo, 207

(ver também Receita Administrada)

[Resolução da ANATEL nº 690/2018]

TV Digital

(ver também Digitalização)

Redistribuição e Digitalização de Canais de TV e RTV

destinação de saldo remanescente relativo ao ressarcimento dos custos decorrentes da, 206

[Portaria MCTIC $n^{\circ} 3.045$, de 7 de junho de 2018]

\section{$\mathbf{U}$}

UHF

(ver Ultra High Frequency (Freqüência Ultra Alta))

Ultra High Frequency (Freqüência Ultra Alta)

dispensa da disponibilização dos Canais de Programação de Distribuição 
Obrigatória de estação de prestadora de SeAC que opera em lagura de banda de $6 \mathrm{MHz}$ na faixa de, 209

[Resolução da ANATEL n ${ }^{\circ}$ 692/ 2018]

Unidade Receptora Decodificadora (ver Unidade Receptora Decodificadora) (ver URD)

Unidade Receptora Decodificadora direito à URD que permita a utilização de recursos de acessibilidade no SeAC, 209 [Resolução da ANATEL n ${ }^{\circ}$ 692/ 2018]

\section{Universalização, 215}

(ver também Fundo de Universalização dos Serviços de Telecomunicações)

(ver também Plano Geral de Metas de Universalização do STFC no Regime Público)

[Acórdão do Conselho Diretor da ANATEL, de 3 de janeiro de 2018 (Ref. no 11/2018)]

Políticas de Telecomunicações orientação dos compromissos de expansão dos serviços de telecomunicações fixados pela ANATEL, 202

[Decreto ${ }^{\circ} 9.612 / 2018$ ]

Telecomunicações Brasileiras S.A. mantidas certas atribuições de universalização após substituição do Programa Nacional de Banda Larga e do Programa Brasil Inteligente pelas políticas públicas de telecomunicações aprovadas pelo Decreto 9.612, de 17 de dezembro de 2018, 202

[Decreto ${ }^{\circ}$ 9.612/2018]

Universalização e Massificação, 187

URD

(ver Unidade Receptora Decodificadora) URD, 209

[Resolução da ANATEL no 692/ 2018]

Uso em Caráter Primário

(ver Uso em Caráter Primário (Radiofreqüiência))

Uso em Caráter Primário (Radiofreqüência)

Serviço de Retransmissão de Televisão

$$
\begin{aligned}
& \text { sua autorização para execução em } \\
& \text { caráter primário restrito às } \\
& \text { concessionárias do serviço de } \\
& \text { radiodifusão de sons e imagens, } 207 \\
& \text { [Portaria MCTIC no } \\
& \text { dezembro de 2018] }
\end{aligned}
$$

\section{Usuário}

Acesso a Informação

inclusão de dever à prestadora de serviços de telecomunicações para que divulgue, de forma clara e de fácil compreensão pelos usuários, tabela com o valor das tarifas e preços praticados e a evolução dos reajustes realizados nos últimos cinco anos, 199 [Lei ${ }^{\circ}$ 13.673/2018]

\section{INTERNET}

altera o rol de exceções ao direito do usuário da internet de exclusão definitiva dos dados pessoais que tiver fornecido a determinada apliação de internet, 199

[Lei $\left.{ }^{\circ} 13.709 / 2018\right]$

Usuário / Consumidor, 197

V

Valor Adicionado

(ver Serviço de Valor Adicionado)

Voz do Brasil

(ver Horário de Retransmissão Obrigatória do Programa Oficial dos Poderes da República)

\section{Voz do Brasil}

definição do horário de retransmissão da, 198

$$
\text { [Lei no 13.644/2018] }
$$

ARANHA, M.; LIMA, J.; QUELHO, R. Regulação do Setor de Telecomunicações em 2018. Revista de Direito, Estado e Telecomunicações, v. 11, n. 2, p. 177-230, outubro 2019.

DOI: https://doi.org/10.26512/lstr.v11i2.27083 
ARANHA, M.; LIMA, J.; QUELHO, R. Regulação do Setor de Telecomunicações em 2018. Revista de Direito, Estado e Telecomunicações, v. 11, n. 2, p. 177-230, outubro 2019.

DOI: https://doi.org/10.26512/lstr.v11i2.27083 